
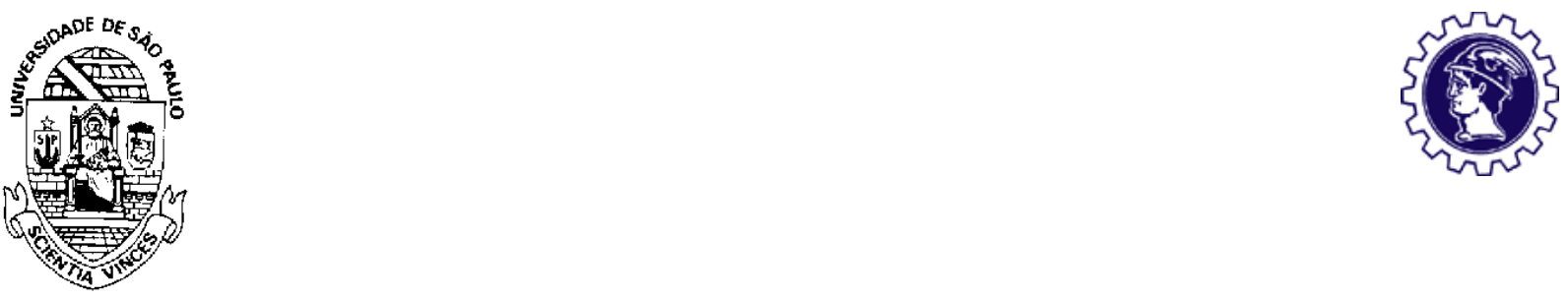

UNIVERSIDADE DE SÃO PAULO

FACULDADE DE ECONOMIA, ADMINISTRAÇÃO E CONTABILIDADE DEPARTAMENTO DE ADMINISTRAÇÃO

PROGRAMA DE PÓS-GRADUAÇÃO EM ADMINISTRAÇÃO

METODOLOGIA PARA DETERMINAÇÃO DO VALOR DE EMPRESAS DE BIOCOMBUSTÍVEIS NO BRASIL

Anderson J. Cruz

Orientador: Prof. Dr. Almir Ferreira de Sousa

SÃO PAULO

Julho de 2007 
Profa. Dra. Suely Vilela

Reitora da Universidade de São Paulo

Prof. Dr. Carlos Alberto Azzoni

Diretor da Faculdade de Economia, Administração e Contabilidade

Prof. Dr. Isak Kruglianskas

Chefe do Departamento de Administração

Prof. Dr. Lindolfo Galvão de Albuquerque

Coordenador do Programa de Pós-Graduação em Administração 


\title{
METODOLOGIA PARA DETERMINAÇÃO DO VALOR DE EMPRESAS DE BIOCOMBUSTÍBEIS NO BRASIL
}

\author{
Projeto de Dissertação apresentado ao Departamento de \\ Administração da Faculdade de Economia, \\ Administração e Contabilidade da Universidade de São \\ Paulo como requisito para obtenção do título de Mestre \\ em Administração.
}

Orientador: Prof. Dr. Almir Ferreira de Sousa

\section{SÃO PAULO}

Julho de 2007 
FICHA CATALOGRÁFICA

Cruz, Anderson J.

METODOLOGIA PARA DETERMINAÇÃO DO VALOR DE EMPRESAS DE BIOCOMBUSTIIVEIS NO BRASIL. /.

Anderson J. Cruz ;orientador Prof. Dr. Almir Ferreira de Sousa. São Paulo, 2007.

p.159.

Dissertação (Mestrado - Programa de Pós Graduação - Departamento de Administração da Universidade de São Paulo) - FEA-USP da Universidade de São Paulo.

1. Avaliação de Empresas 2. Biomassa 3. Biocombustíveis 4. Agroenergia 5. Biodiesel 6. Etanol 
Aos meus Mestres do Saber em todos os níveis, sempre presentes. 
AGRADECIMENTOS

"Todos que conheci ao longo da minha jornada, presentes ou que estiveram de passagem foram meus Mestres em diferentes níveis, portanto dedico este trabalho a todos Eles." 


\section{RESUMO}

O Brasil vem se destacando como pioneiro no desenvolvimento de um setor ainda incipiente no âmbito mundial. Um setor que apresenta tecnologia nacional e atende a uma busca para soluções ecológicas frente a uma exigência social cada vez mais estreita para a redução de poluentes. Este setor é conhecido como biocombustíveis que podemos englobar a produção de álcool, biodiesel, biogás, e carvão vegetal.

O trabalho propõe estudar uma parte do setor de agroenergia conhecido como o setor de biocombustíveis, delimitado pelos segmentos: biodiesel, álcool, carvão vegetal para uso siderúrgico e biogás, apresentando suas vantagens econômicas, sociais e ecológicas. Propõe criar um modelo econômico de avaliação de empresas deste setor, buscando na literatura os modelos de avaliação existentes, discutindo a aplicação de cada um deles de forma a satisfazer os diversos níveis de demanda pelas diferentes necessidades dos leitores. Além disso, apresenta as dificuldades na busca de dados que poderão ser utilizados em outros setores com o mesmo grau de maturidade.

Por ser um trabalho de avaliação de empresas, existe a necessidade de um aprofundamento das premissas e estudo dos parâmetros a serem considerados, desta forma, surge a necessidade de um estudo do setor amplo. Desta forma, por falta de dados deu-se atenção apenas nos segmentos de etanol e biodiesel.

Para os diferentes segmentos deste setor, foi necessário utilizar diferentes fontes de informação: para o segmento de biodiesel, pesquisou empresas de porte padrão de mercado e adotou um fluxo de caixa para determinar este valor, utilizando diferentes insumos (algodão, soja, girassol e mamona) nas diferentes regiões do Brasil. No segmento de álcool, foi utilizada uma empresa já existente buscando aproximar de um modelo para o cálculo de empresas em diferentes proporções álcool/açúcar e estruturas de capital. 


\begin{abstract}
Brazil still comes if detaching as pioneering in the development of a sector incipient in the world-wide scope. A sector that presents national technology and takes care of to a search for ecological solutions front to a social requirement each narrower time for the reduction of pollutants. This sector is known as that we can mention the alcohol production, biodiesel, biogas and vegetal coal agroenergy.
\end{abstract}

The work considers studying a part of the known sector of agroenergy as the sector of biofuels, delimited for the segments alcohol, biodiesel and vegetal coal, presenting its economic, social and ecological advantages. It considers creating a economic model of evaluation of companies of this sector, searching in literature the existing models of evaluation, arguing the application of each one of them of form to satisfy the diverse levels of demand for the different necessities of the readers.

Moreover, it presents the difficulties of search of data that could also be used in other sectors in the same maturity degree. For the different segments of this sector, it was necessary to use different sources of information: for the segment of biodiesel, it searched transport companies market standard and adopted a box flow to determine this value, using different products (cotton, soy, sunflower and mamona) in the different regions of Brazil. In the alcohol segment, an existing company was used already searching to approach to a model for it calculates of companies in different ratios alcohol/sugar and structure of capital. 


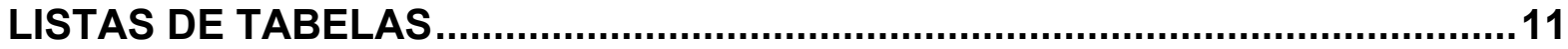

LISTA DE GRÁFICOS

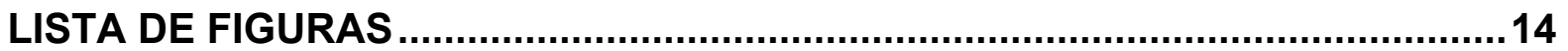

1. INTRODUÇÃO

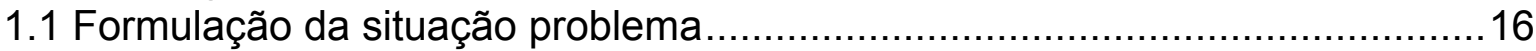

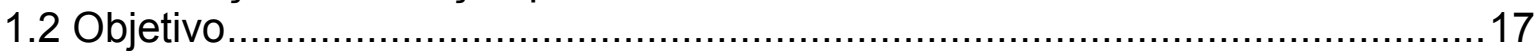

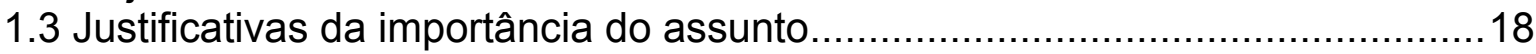

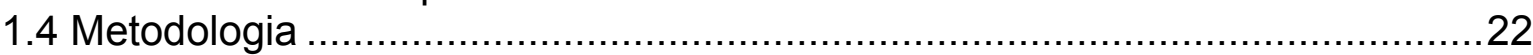

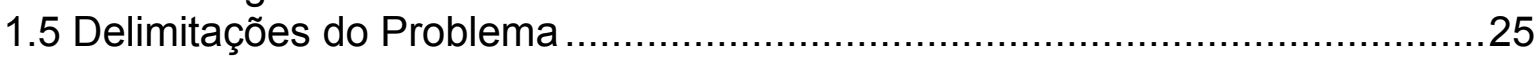

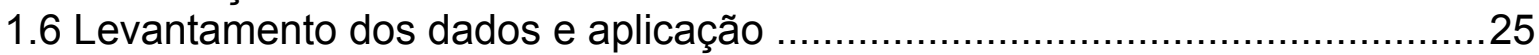

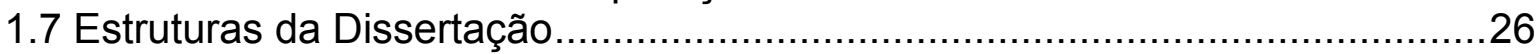

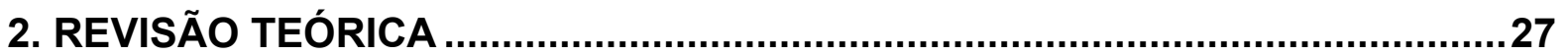

2.10 princípio de avaliação de empresas.................................................27

2.2 Principais metodologias de avaliação de empresas ...................................28

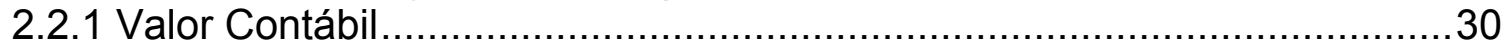

2.2.2 Modelo de desconto de dividendos ....................................................

2.2.3 Método de Fluxo de Caixa Descontado (DCF).....................................33

2.2.3.1 Componentes da metodologia do Fluxo de Caixa Descontado ...........................36

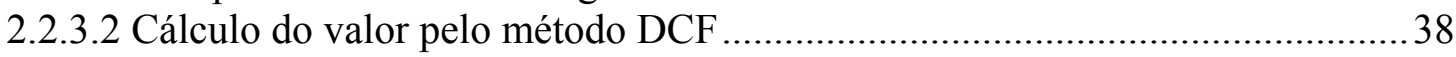

2.2.3.3 Custo ponderado de capital ........................................................................ 41

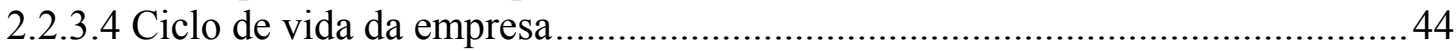

2.2.4 Avaliação Relativa de Múltiplos.........................................................50

2.2.5 Opções Reais como método de avaliação ............................................52

2.2.6 Riscos na avaliação de empresas no Brasil..............................................55

3. O Setor de Biocombustíveis no Brasil e no mundo .......................................58

3.1 Definições do setor de biomassa como fonte de energia ..............................58

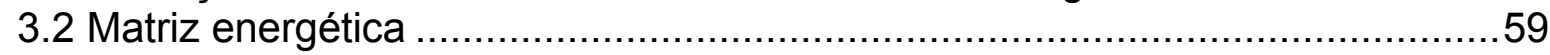

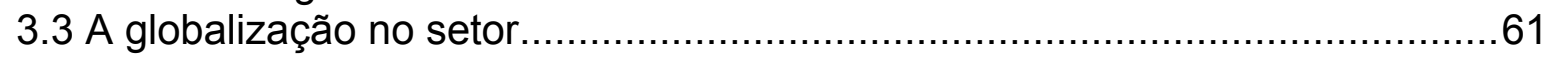

3.4 Importâncias na redução das emissões de gases .......................................62

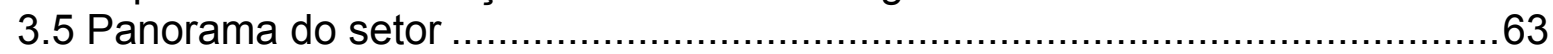

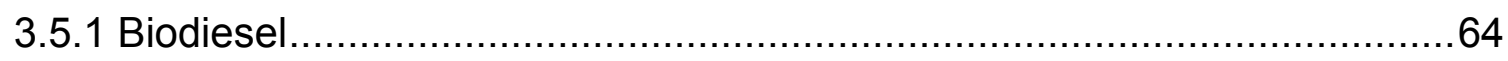

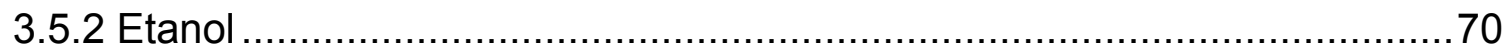

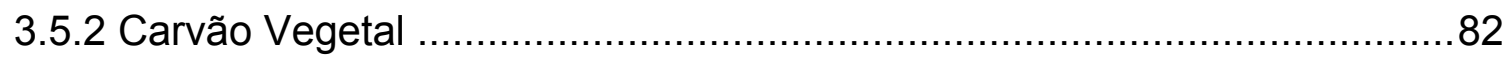

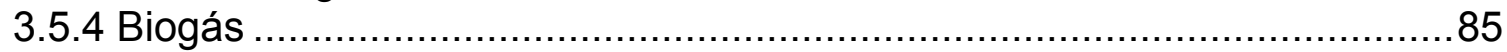

3.5.5 Biomassa como fonte de Energia Elétrica.................................................

4. Aplicação do modelo de avaliação de empresas no setor de Biocombustíveis

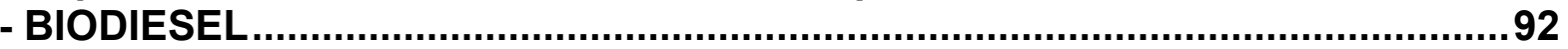

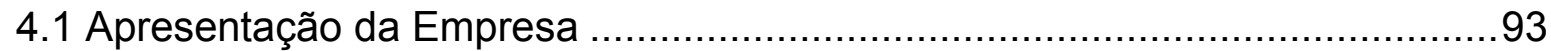

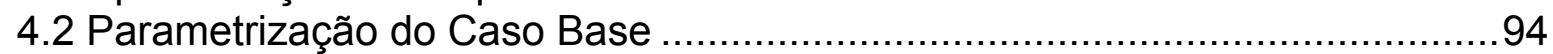

4.2.1 Custo de investimento, Financiamento e Depreciação .............................94

4.2.2 Custo de operação da usina de biodiesel ...............................................95

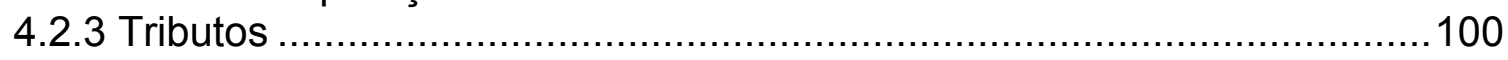

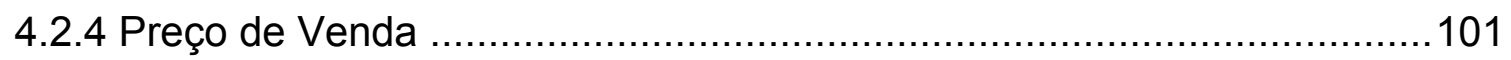




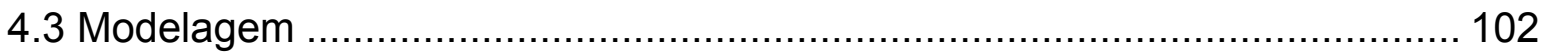

4.3.1 Projeção dos dados da empresa .................................................. 103

4.3.2 Taxa de desconto para o fluxo de caixa livre para o acionista. .............. 105

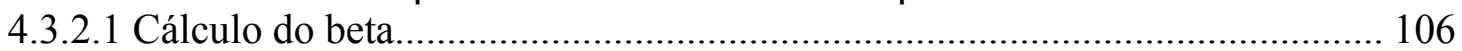

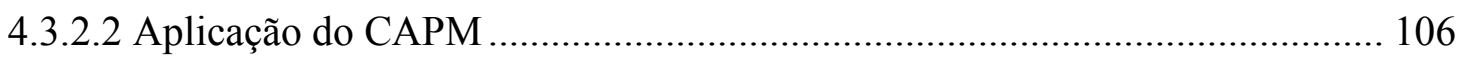

4.3.2.3 Cálculo do Custo Médio Ponderado de Capital - WACC ............................... 108

4.4 Aplicação do método de avaliação ao caso base ...................................... 111

4.4.1 Fluxo de caixa para o acionista ...................................................... 111

4.4.2 Fluxo de caixa para a empresa........................................................ 112

4.4.3 Sensibilidade sobre a Taxa de Desconto .......................................... 114

4.4.4 Múltiplos setoriais ................................................................... 116

4.5 Avaliação pela Teoria das Opções ....................................................... 118

4.6 Avaliação de empresa pelo Valor Contábil............................................... 119

5. Aplicação do modelo de avaliação de empresas no setor de

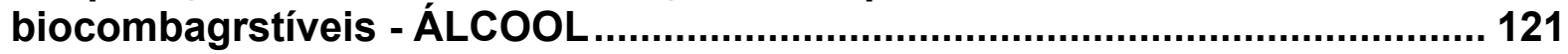

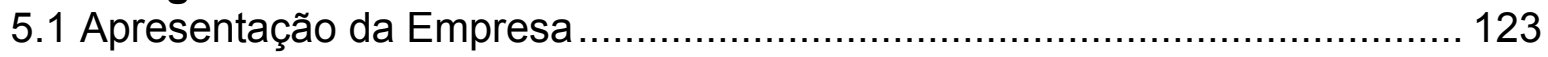

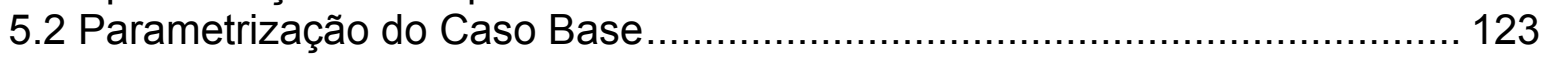

5.2.1 Produção e produtos comercializados ................................................ 124

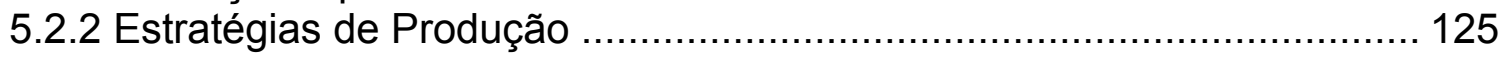

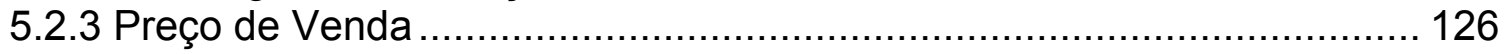

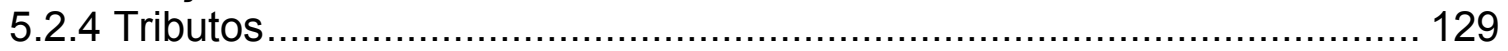

5.2.5 Custo de operação da usina de álcool............................................ 130

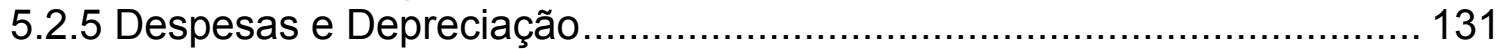

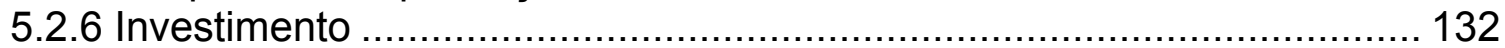

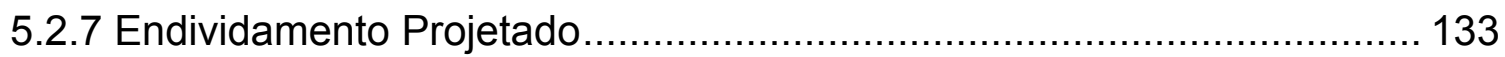

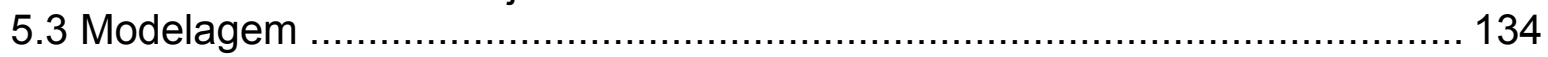

5.3.1 Projeção dos dados da empresa ................................................... 135

5.3.2 Taxa de desconto para o fluxo de caixa livre para o acionista. .............. 136

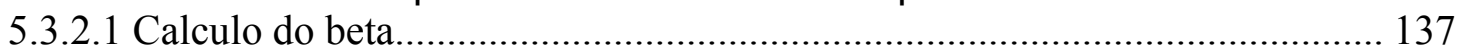

5.3.2.2 Aplicação do CAPM ................................................................................... 138

5.3.2.3 Cálculo do Custo Médio Ponderado de Capital - WACC ............................... 140

5.4 Aplicação do método de avaliação ao caso base ...................................... 142

5.4.1 Fluxo de caixa para o acionista ............................................................ 142

5.4.2 Fluxo de caixa para a empresa........................................................... 143

5.4.3 Resultados e Análise de Sensibilidade ............................................... 145

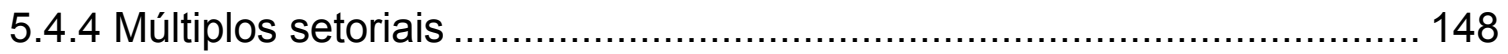

5.5 Avaliação pela Teoria das Opções ........................................................... 150

5.6 Avaliação de empresa pelo Valor Contábil................................................. 150

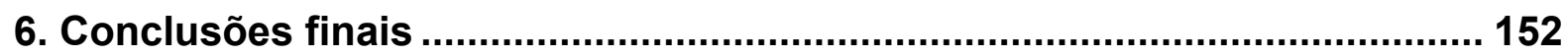

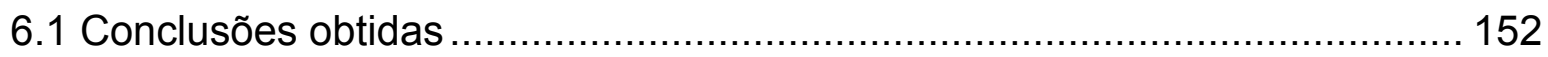

6.2 Sugestões para trabalhos futuros............................................................ 153

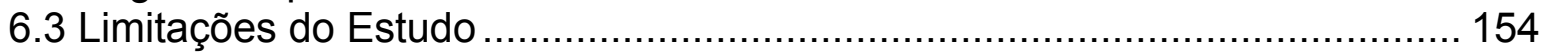

REFERÊNCIAS BIBLIOGRÁFICAS ......................................................... 155 


\section{LISTAS DE TABELAS}

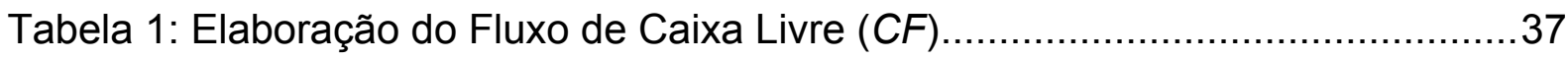

Tabela 2 - Empresas autorizadas a operar com o biodiesel no Brasil .....................67

Tabela 3: Potencial de produção de etanol e açúcar nos países em desenvolvimento .71

Tabela 4 - Setor de açúcar e álcool 2006/2007 …............................................79

Tabela 5 - Setor de açúcar e álcool ano 2012/2013 ..........................................79

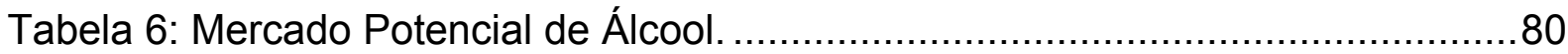

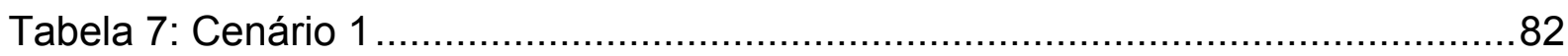

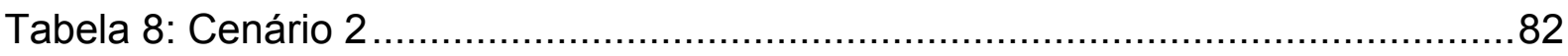

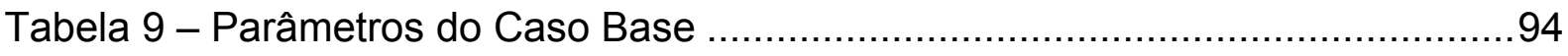

Tabela 10 - Composição e características dos financiamentos ..............................95

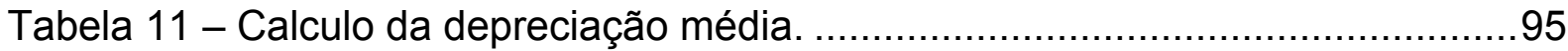

Tabela 12 - Quadro de custo de produção do biodiesel por região..........................98

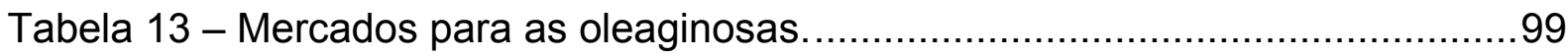

Tabela 14 - Formação do custo de fabricação do biodiesel ..................................100

Tabela 15 - Tabela de tributos para o biodiesel................................................. 101

Tabela 16 - Ganhos de produtividade do etanol.............................................103

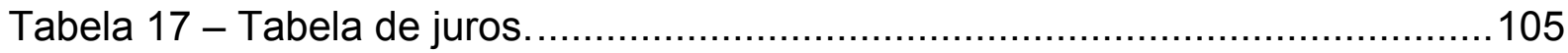

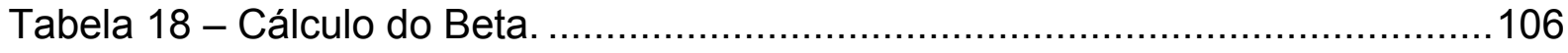

Tabela 19 - Aplicação do CAPM - Taxas ao ano …………..............................107

Tabela 20 - Taxa de Financiamento. ................................................................ 109

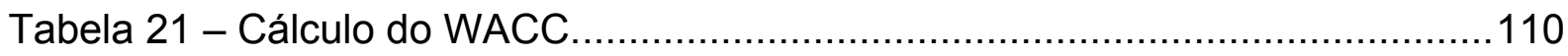

Tabela 22 - Valor presente do fluxo de caixa para acionista. ...............................112

Tabela 23 - Valore presente do fluxo de caixa para empresa ................................113

Tabela 24 - Diagrama de composição de valores (em R\$ mil) ..............................113

Tabela 25 - Resultado do Valor da Empresa ....................................................115

Tabela 26 - Resultado leilão da ANP (11-12/julho/06) .....................................116

Tabela 27 - Parâmetros do modelo comparativo por região e produto. ..................117

Tabela 28 - Comparativo entre diferentes regiões e insumos. .............................118

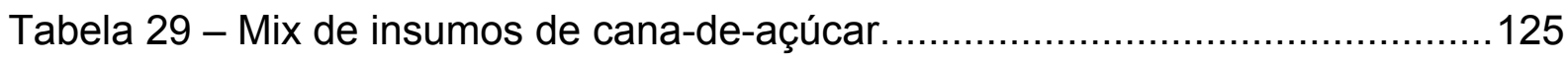

Tabela 30 - Tabela de tributos para o açúcar/álcool.............................................129

Tabela 31 - Distribuição de Investimento ……………....................................132 


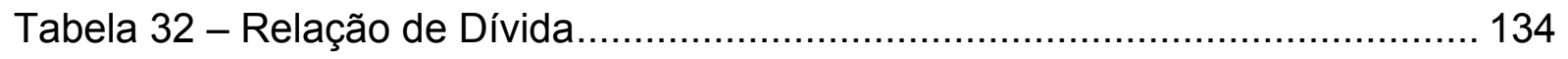

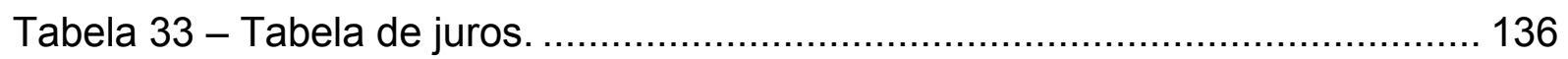

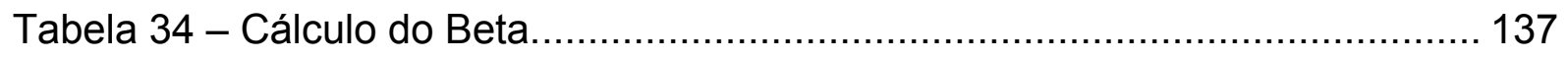

Tabela 35 - Aplicação do CAPM - Taxas ao ano ................................................ 139

Tabela 36 - Taxa de Financiamento. ........................................................... 140

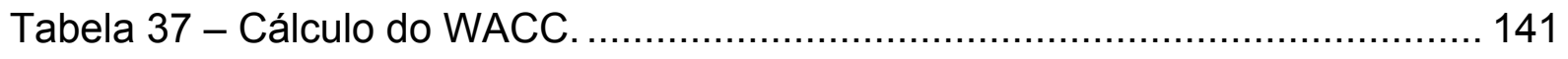

Tabela 38 - Valore presente do fluxo de caixa para acionista.............................. 143

Tabela 39 - Valore presente do fluxo de caixa para empresa.............................. 144

Tabela 40 - Diagrama de composição de valores (em R\$ mil) .............................. 145

Tabela 41 - Simulação da variação de preço .................................................... 146

Tabela 42 - Simulação de variação da taxa. ....................................................... 147

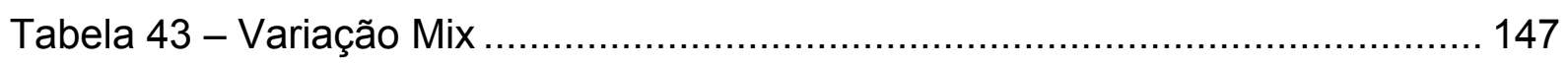

Tabela 44 - Resultado do valor da empresa por região. .................................... 149

Tabela 45 - Comparativo entre diferentes regiões. .......................................... 149 


\section{LISTA DE GRÁFICOS}

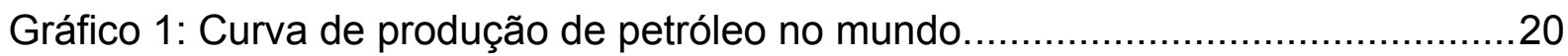

Gráfico 2: Oferta Mundial de Energia Primária, 2002/Oferta de Energia no Brasil, 2002. .59

Gráfico 3: Evolução da Demanda Mundial de energia entre 1850-2100 ..................60

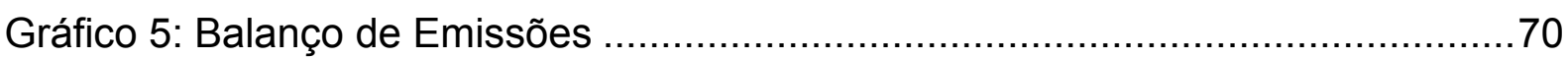

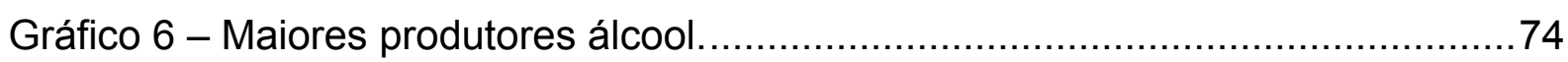

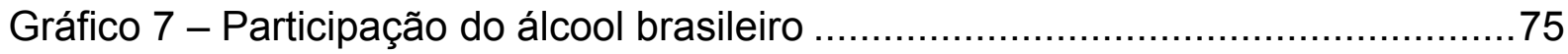

Gráfico 8 - Produção e Produtividade da cana-de-açúcar no Brasil. .......................76

Gráfico 9 - Produção Nacional de Cana-de-açucar............................................77

Gráfico 10 - Projeção do mercado de álcool no Brasil...........................................78

Gráfico 11 - Projeção da produção de veículos flex ..........................................78

Gráfico 4 - Histórico do preço da soja PR ...................................................100

Gráfico 13 - Market share em moagem de cana no Brasil .................................124

Gráfico 15 - Relação de Produção de Álcool e Açucar.........................................126

Gráfico 14: Competitividade Internacional - Curva de Aprendizado do Etanol ........127

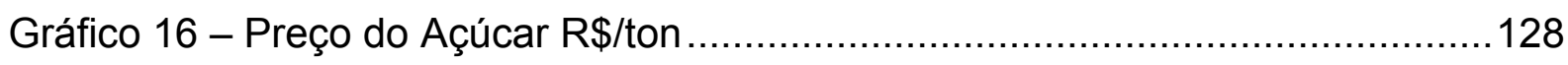

Gráfico 17 - Preço álcool R\$/L..................................................................128 


\section{LISTA DE FIGURAS}

Figura 1: Valor de Livro não ajustado da empresa ....................................... 30

Figura 2: Curva de maturidade de uma empresa genérica................................ 46

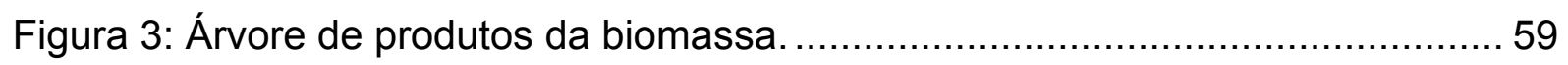

Figura 4: Produção, custo do etanol e do açúcar comparado com mundo 2005 ..... 75

Figura 5: Mapeamento de possíveis áreas para o desenvolvimento da cana-de-

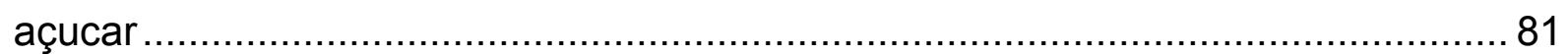

Figura 6: Competitividade Internacional - Vantagens naturais Brasil ..................... 83

Figura 7: Transferência do setor florestal .................................................... 83 


\section{INTRODUÇÃO}

Apesar de o setor apresentar características de commodities, ainda se encontra em um estágio de desenvolvimento comparados a outros setores, desta forma traz um desenvolvimento tecnológico que engloba profissionais, desenvolvimento do conhecimento, equipamentos, processos e conseqüentemente o desenvolvimento da indústria da química fina como produtos da biomassa para fins energéticos. Este setor apresenta todas as características hibridas de um setor de tecnologia: falta de dados históricos, ainda não atingiu a maturidade, falta de previsibilidade com a inserção do setor brasileiro no contexto mundial e pouco presente no mercado de capitais.

Inserido num mercado globalizado, o Brasil se destaca por representar um importante player no setor da energia a partir da biomassa. Como conseqüência deste desenvolvimento, o setor passa por um processo de expansão e reestruturação, sendo necessário desenvolvimento do conhecimento e estudo específico para atender essa crescente demanda. Este setor pela sua importância e expressão tornar-se-á o foco de estudo principalmente importante para estudo na área de finanças.

O desenvolvimento deste setor irá demandar um ferramental para mensurar o valor dos investimentos na mesma linha que cresce o interesse por investimento e capital. Este trabalho visa contribuir para um arcabouço teórico de avaliação de empresas, cujo objetivo principal é aplicar os modelos de avaliação de empresas mais convenientes para atender o setor de energia a partir da biomassa, bem como metodologias e modelos para previsão dos principais drivers do setor.

A idéia de desenvolvimento sustentável determina os limites de um sistema energético baseado na energia fóssil, incluída a nuclear. De acordo com GRIMONI, GALVÃO, UDAETA (2004) o uso e combustíveis fósseis têm agravado a sustentabilidade e o equilíbrio do planeta, tais como:

- A população mundial está na eminência do esgotamento das reservas de energia: petróleo, carvão e gás natural;

- Os ecossistemas terrestres vêm sofrendo desequilíbrios gerados pelo uso de combustíveis fósseis; 
- Desequilíbrios no comércio, gerados pelas concentrações de fontes de energia de energia, causando custos elevados e dependências à importação de combustíveis.

As mudanças climáticas e o efeito estufa são considerados os problemas mais graves causados pelo uso da energia. O efeito estufa é causado pelo aumento da concentração dos "gases do efeito estufa" (GEE ou GHG, do inglês greenhouse gases) na atmosfera, tais como o gás carbônico $\left(\mathrm{CO}_{2}\right)$, o metano $\left(\mathrm{CH}_{4}\right)$, o óxido nitroso $\left(\mathrm{N}_{2} \mathrm{O}\right)$. Esses gases capturam parte da radiação infravermelha que a Terra devolve para o espaço, fazendo com que ocorra com a Terra algo parecido com o que ocorre em uma estufa. Como conseqüência tem-se o aumento da temperatura na superfície do planeta.

Não bastassem tais cenários estamos em frente a um setor ainda no início da sua expansão, com características de empresas de capital fechado, pouca informação no mercado e que possuí fontes insuficientes em outros países. Desta forma, todo um desenvolvimento do uso das teorias financeiras adaptadas ao setor em questão se faz necessária.

\subsection{Formulação da situação problema}

Para avaliar uma empresa, extraem-se informações de três fontes. A primeira se refere à demonstrações financeiras atuais da empresa. Essas demonstrações são usadas para determinar qual é ou foi a lucratividade dos investimentos da empresa, o quanto ela reinveste para gerar crescimento futuro e para fornecer todos os dados usados em qualquer avaliação. A segunda trata do histórico da empresa, tanto em termos de lucros quanto de preços do mercado. O histórico de lucros e receitas de uma empresa nos permite julgar o grau de ciclicidade da atividade da empresa e o crescimento por ela apresentado, e o histórico de preços nos ajuda a medir o risco. Finalmente, é possível examinar os concorrentes ou os grupos de pares da empresa para determinar o quanto ela é melhor ou pior do que seus concorrentes e, ainda, para estimar dados fundamentais de risco, crescimento e fluxo de caixa.

O problema de empresas de novos setores não está no fato de perderem dinheiro, não terem histórico, ou terem volume substancial de ativos intangíveis. O ponto é que estão num momento precoce no seu ciclo de vida e apresentam potenciais em fase de expansão em mercados ainda não atuantes, que tem o potencial de mudar todo um panorama mundial dos 
combustíveis. Este mercado ainda não está estabelecido e como reagirão os consumidores e países frente a mudança de suas matrizes de energia primária.

O maior problema é o de estimativa. O valor de uma empresa continua a ser o valor presente dos fluxos de caixa previstos dos seus ativos, mas o mais provável é que seja muito mais difícil estimar seus fluxos de caixa, taxa de desconto e perpetuidade.

Por se tratar de um setor ainda no início do seu desenvolvimento tanto no Brasil como no mundo, portanto ainda sem muita importância no comércio mundial, porém com um grande potencial de crescimento, faltam estudos e informações, entre outros:

- Falta de empresas de capital aberto;

- Setor ainda não maduro - dificuldade de projetar cenários;

- Inexistência de parâmetros de mercado;

- Falta de processo e adaptação de metodologias de avaliação de empresas neste setor.

Este setor projeta como um dos mais importantes da econômica brasileira, pois apresentam grande capacidade de crescimento e investimentos. Mostrou-se viável em todos os campos: econômico, social e ambiental.

Apesar de aparentemente representar um setor de agronegócio, existem peculiaridades que são: desenvolvimento tecnológico para atender a demanda, bem como formação de profissionais qualificados. Desta forma, expansão, abertura comercial e pulverização de empresas irão demandar teorias e estudos específicos.

Esse processo irá gerar fusões, aquisições, lançamento de empresas no mercado de capital, portanto surge a necessidade de todo um ferramental teórico de avaliação de empresas.

\subsection{Objetivo}

O objetivo geral deste trabalho é avaliar a aplicabilidade das ferramentas disponíveis para o cálculo do valor de empresas de biomassa para fins energéticos no Brasil. 
Além da aplicabilidade o estudo consiste em apresentar as diferentes metodologias de avaliação de empresas, tendo como estudo, suas características, funcionalidade, limitações e vantagens. Servindo de parâmetros para aplicação em outras empresas que possuam as mesmas características das empresas do setor em estudo, pois serão discutidos aspectos relacionados com: a falta de dados de mercado, grande variabilidade na previsão dos principais fatores de entrada para a valoração e empresas iniciando processo de entrada no mercado de capitais.

Através de casos de empresas, aplicar as metodologias de avaliação de empresas que melhor se adaptem ao setor em estudo. Envolve a formulação de hipóteses, prévio conhecimento do setor e levantamento de dados, ou seja, formular parâmetros, tais como os principais drivers, cuja função é aumentar a previsibilidade do fluxo de caixa, taxas de desconto, etc.

Passando do contexto cientifico para a aplicação em empresas do mercado, fornecerá recursos e dados para avaliações futuras em empresas do setor, além de difundir ferramentas, técnicas e metodologias que, aplicados com diferentes técnicas de valoração, possam proporcionar à teoria de finanças um arcabouço ferramental para futuros trabalhos práticos.

Apresentar ao leitor ou pesquisador uma fonte de informação sobre o setor de biocombustíveis, suas principais características, aplicabilidade dos insumos, formação de preços e riscos envolvidos.

\subsection{Justificativas da importância do assunto}

O mundo passa por um momento de mudanças de comportamento em que a variável meio ambiente está na pauta de discussão para tornar projetos economicamente viáveis. O aumento do uso de combustíveis fósseis tem provocado um aumento na emissão de gases que contribuem para aumentar as conseqüências do efeito estufa.

Segundo STERN (2006) num estudo apresentado para o Governo Britânico, os atuais níveis de concentração de $\mathrm{CO}_{2}$ na atmosfera de 430 ppm (280 ppm antes da Revolução Industrial) poderá provocar um aquecimento de até $4^{\circ}$ na temperatura do planeta nas próximas décadas.

Associada ao aumento da temperatura as principais conseqüências estão relacionados com: 
- Aumento dos níveis dos mares obrigando a evacuação de 200 milhões de pessoas;

- Desertificação de áreas próximas aos trópicos e falta d'água, agravando os problemas sociais em países da África e Sudeste Asiático;

- Proliferação de doenças tropicais em países de clima temperado;

- Extinção de até $15 \%$ - 40\% das espécies do planeta.

As perdas provocadas pelas mudanças climáticas têm aumentado ano a ano de acordo com STERN (2006); em 1990 as perdas representaram 0,2\% do PIB Mundial (US\$60bilhões) em 2005 as perdas foram recordes chegando a $0,5 \%$ do PIB (200 bilhões).

Alguns dos perigos iminentes que confrontam o desenvolvimento humano no planeta são a falta de energia disponibilizada para os países pobres e o domínio opressivo do uso da energia atômica e fóssil no mundo, deixando aparecer o dilema de que o atual sistema energético do mundo é a principal razão para o desenvolvimento insustentável. A relação entre o desenvolvimento dos PEDs (Países em Desenvolvimento) e a dependência de energia ficou evidente nas crises do petróleo entre 1973 e 1982 (haja visto que nesse período a dívida dos PEDs subiu de 200 bilhões para 1,2 trilhão de dólares, da qual não se recuperaram ainda), e há indícios de que o petróleo se torne escasso nas próximas décadas, levando os PEDs problemas sociais e até a existenciais.

Adotar políticas de diversificação energética através do uso de fontes renováveis, especialmente a adoção da biomassa traz vantagens em todas as esferas:

\section{Vantagens estratégicas}

Aumentar a diversificação da matriz energética de um país e reduzir sua dependência de combustíveis fósseis são medidas estratégicas importante para a garantia de suprimento de energia. Desta maneira não se fica tão vulnerável às oscilações dos preços do petróleo e às instabilidades políticas dos países produtores (COELHO, 1999).

Outra vantagem estratégica é a redução dos gastos com importação de petróleo. No Brasil, com o Programa do Álcool (PROALCOOL), o país economizou entre 1975 e 2002, US\$ 52,1 bilhões em divisas (GOLDEMBERG et al., 2003). 
Em períodos recentes, os países, principalmente os desenvolvidos, passaram a considerar a dependência de importação de petróleo e derivados como uma situação de risco para a economia local. Essa sensação de risco se agravou com a crise política na Venezuela e os conflitos no Oriente Médio.

Além da instabilidade política e social nos países responsáveis por grande parte da oferta mundial de petróleo que podem afetar a oferta de petróleo no curto prazo, alguns estudos começam a apontar para incerteza quanto a oferta de petróleo no médio e longo prazo. Pesquisa realizada por DUNCAN; YOUNGQUIST (1998) sobre o ciclo de vida do petróleo apontam para a incerteza quanto a oferta de petróleo no longo prazo. O referido trabalho utilizou séries históricas da produção das 42 nações responsáveis pela produção de mais de 98\% do petróleo utilizado no mundo, agrupadas em 7 regiões e no mundo. Pelo referido trabalho a produção de petróleo no mundo apresentará o pico de sua oferta em 2006. A partir desta data, se iniciará o processo de retração na oferta mundial de petróleo. Tal retração será inicialmente desencadeada pelos países não pertencentes a OPEP e posteriormente, em 2011, os países da OPEP também apresentarão declínio na oferta mundial.

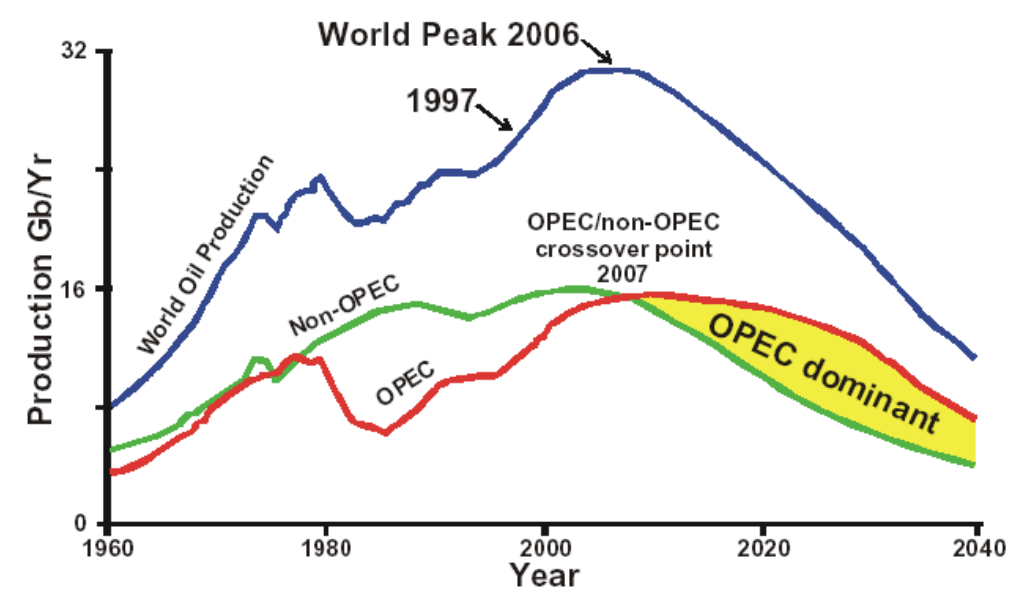

Gráfico 1: Curva de produção de petróleo no mundo.

Fonte: DUNCAN; YOUNGQUIST (1998)

\section{$\underline{\text { Vantagens Ambientais }}$}

Cerca de $80 \%$ do consumo mundial de energia primária é baseado em combustíveis fósseis (carvão, petróleo e gás) e a queima destes combustíveis é a principal responsável pela emissão de dióxido de carbono $\left(\mathrm{CO}_{2}\right)$, um dos responsáveis pelo aquecimento global e as mudanças climáticas (GOLDEMBERG, 2004). A utilização de fontes renováveis é uma das maneiras de reduzir a emissão de gases de efeito estufa, além de auxiliar na redução dos impactos ambientais locais, regionais e globais. A biomassa sustentável, bagaço de cana-de-açúcar, por 
exemplo, apresenta balanço nulo de emissões, pois as emissões resultantes da queima do bagaço são absorvidas e fixadas pela planta durante o seu crescimento.

Outro exemplo é a utilização de biocombustíveis; como tem sido observado no Brasil desde a adoção do etanol como combustível, total ou parcialmente, em toda a frota de veículos leves. Dados da CETESB (Companhia de Tecnologia de Saneamento Ambiental do Estado de São Paulo) revelam que os níveis de emissões de monóxido de carbono foram imediatamente reduzidos em cerca 50\% (CETESB, 2004).

\section{Vantagens Sociais}

A geração de empregos tem sido reconhecida como uma das maiores vantagens das energias renováveis, em espacial a biomassa. Isso porque a geração de empregos diretos e indiretos promove um ciclo virtuoso de aumento dos níveis de consumo e qualidade de vida, inclusão social, geração de mais atividades econômicas, fortalecimento da indústria local, promoção do desenvolvimento regional e a redução do êxodo rural. Em especial a produção de biomassa é uma atividade que envolve muitos empregos.

Mais uma vantagem social que merece ser mencionada é que a redução dos níveis de emissão, melhora a qualidade do ar, que está diretamente relacionada de saúde (não só problemas respiratórios) e reduz, conseqüentemente, os gastos públicos no setor da saúde (internações, medicamentos).

Apesar das vantagens mencionadas, surgem algumas perguntas que serão abordadas no trabalho: Como lidar com empresas de setores com previsibilidade tão volátil, o que revela o futuro para setores no Brasil que pode nos colocar como lideres do desenvolvimento limpo energia renovável? Eis aqui um trabalho que propõem apresentar uma metodologia para tratar desses assuntos e apresentar soluções para alguns dos problemas em questão.

Porque tratar um setor que aparentemente defini seus produtos como commodities? Algumas características podem ser apontadas:

- Um setor que não possui concorrentes em potencial em outros países;

- Características climáticas e de solo permite ao Brasil liderar esta atividade tanto no aspecto tecnológico, pesquisas e mercado; 
- Existe uma tendência para este tipo de produto e mercado em forte expansão, devido às questões climáticas, em que surge a necessidade de novos produtos para atender o mercado;

- Como exemplo o álcool serve de matéria prima para a tecnologia de células de combustíveis - hidrogênio (combustível do futuro);

- Tem uma variabilidade significativa na previsibilidade das variáveis.

O Brasil pode atuar nas diferentes fontes de energia proveniente da biomassa: Álcool (combustíveis e geração de energia elétrica), Biodiesel (combustíveis), Biogás (geração de energia elétrica), Carvão Vegetal (fonte de energia para o setor de siderurgia e geração de energia elétrica).

Além das justificativas citadas, o estudo poderá contribuir para:

- Avaliação de empresas em processos de M\&A ("Merger and Acquisition");

- Avaliação de portfólio;

- Servir de apoio para investidores em um mercado de capitais para este setor ainda embrionário.

Apesar do grande potencial de crescimento do uso da biomassa para fins energéticos no Brasil, este ainda encontra-se num estágio inicial, tendo pouca relevância no mercado internacional para atender uma demanda cada vez maior de políticas para promover a sustentabilidade dos meios energéticos, estabilizando a concentração de $\mathrm{CO}_{2}$ na atmosfera. Apesar de dezenas de empresas, apenas 2 pertencentes ao setor são de capital aberto: Grupo Cosan produção de açúcar e álcool e Ecodisel que abriu o capital em novembro/2005 e atua na produção de biodiesel.

\subsection{Metodologia}

Os métodos de pesquisa apresentados por MARCONI; LAKATOS (2000:53) classifica os métodos científicos em quatro tipos: indutivo, dedutivo, hipotético-dedutível e dialético. 
O método indutivo consiste na observância de fenômenos para descobrir a relação entre os fenômenos participativos da observação e definir um modelo genérico para explicar tais fenômenos. $\mathrm{O}$ método dedutivo inicia-se na aceitação de generalidades aceitas ou premissas cientificas e através de argumentos condicionantes chega-se a explicação ou validação da causa-efeitos de tais premissas. O método hipotético-dedutivo é a evolução do dedutivo, ou seja, formular um problema que será testado por experimentação e observação. Por último o método dialético que utiliza a argumentação e análise da contradição para validar ou invalidar teorias cientificas.

\section{Segundo CERBASI (2003):}

"A pesquisa dos modelos disponíveis e sua aplicabilidade à avaliação do objeto de estudo foram feitas através de uma abordagem qualitativa da aplicação do método hipotético-dedutivo a um estudo de caso, onde após levantamento do referencia teórico procurou-se aplicar cada ferramenta e, em alguns casos, falsear tecnicamente seus enunciados para o caso específico, para então propor uma modelagem específica de valoração".

A tipologia de estudos, formulados por MARTINS (2002) é sintetizados em empíricoanalítico, fenomenológico-hermenêutico e crítico-dialético. São caracterizadas primeiramente como:

"Empírico-analíticas: são abordagens que apresentam em comum a utilização de técnicas de coleta, tratamento de dados e análise de dados marcadamente quantitativos. Privilegiam estudos práticos. Têm forte preocupação com relação causal entre variáveis. A validação da prova cientifica é buscada através de testes dos instrumentos, grau de significância e sistematização das definições operacionais"

O estudo acima apresentado tem caráter técnico, restaurador e incrementalista. Típico caso de pesquisas aplicadas, que consiste na sistematização da amostragem e tratamento de dados. Na seqüência de caracterização:

"Fenomenológicas-hermenêuticas: são abordagens que utilizam técnicas não quantitativas. Privilegiam estudos teóricos e análise de documentos e textos. Suas propostas são criticas e geralmente têm marcado interesse de conscientização dos indivíduos envolvidos na pesquisa e manifestam interesse por práticas alternativas. 
Buscam relação entre o fenômeno e a essência, o todo e as partes, o objeto e o contexto. A validação da prova científica é buscada no processo lógico da interpretação e na capacidade de reflexão do pesquisador sobre objeto de seu estudo".

Este tipo foca, entre outros, na aplicabilidade das ferramentas teóricas disponíveis. Método empregado na maior parte do estudo apresentado. O terceiro tipo refere-se a:

“Crítico-dialético: têm como referencial teórico o materialismo histórico, apoiando-se na concepção dinâmica da realidade e das relações dialéticas entre (...) teoria e prática. Além das técnicas utilizadas pelas pesquisas empírico-analíticas e fenomenológicashermenêuticas, utilizam a pesquisa-ação e a pesquisa participante. Privilegiam experiências, práticas, processos/históricos, discussões filosóficas ou análise contextualizadas. (...) a validade da prova científica é fundamentada na lógica interna do processo e nos métodos que explicitam a dinâmica e as contradições internas dos fenômenos e explicam as relações entre homem-natureza, entre reflexão-ação e entre teoria-prática”.

O tipo de estudo citado acima se torna útil na explicação das exceções, como, por exemplo, em casos em que a teoria não se aplica perfeitamente na prática. $\mathrm{O}$ trabalho apresentado nesta dissertação envolve uma parte de cada um dos três tipos de estudo, mas o núcleo do trabalho apresenta fenomenológico - hermenêutica, buscando embasamento teórico para compor uma modelagem de avaliação de empresas que possa ser aplicada a empresas do setor de biocombustíveis, por apresentar características diferenciadas dos demais setores.

Outro ponto importante é a aplicação do positivismo na pesquisa, isto é, considera que os fatos são verdadeiros e que os modelos de análise e valoração são já testados e aceitos. Não foi discutida no trabalho a validade cientifica dos modelos de avaliação de empresa, porém foram apresentados variações na técnica de aplicabilidade.

No tratamento dos dados apresentados pelo modelo, buscou-se uma análise maior qualitativa de validação dos dados apresentando a um estudo analítico para considerações e conclusões apresentadas no trabalho.

YIN (1994) justifica a aplicação de um estudo de caso para aplicação quando "a obtenção de uma conclusão baseia-se em múltiplas fontes de evidencias e nas situações em que há mais 
variáveis de interesse do que dados pontuais (como os obtidos em experiências laboratoriais) para se chegar a um resultado conclusivo singular".

\subsection{Delimitações do Problema}

No estudo proposto de avaliação de empresas aplicado ao setor de biomassa para fins energéticos serão abordados apenas os ativos tangíveis (dimensões físicas e financeiras); os ativos intangíveis que são definidos por REILLY (1996) como: tecnologia, clientes, contratos, processamento de dados, capital humano, marketing, localização, "googwill", capital propriedade/intelectual, não serão o foco de estudo.

No estudo de caso não serão levantados dados das empresas na indústria de biogás, por ainda apresentar pouca representatividade, grande variabilidade de modelos econômicos e falta de dados para estudo. Além do que, essa indústria encontra-se num estado ainda muito embrionário em que o uso de tecnologias mais economicamente viáveis não permite ainda superar a rentabilidade das demais indústrias do setor. Porém, apresentará forte expansão nos próximos anos.

$\mathrm{Na}$ indústria de carvão vegetal, as empresas profissionais de carvão vegetal para uso siderúrgico com as novas tecnologias propostas inexistem. As demais aplicações como uso doméstico na preparação de alimentos e churrasco conhecidos como carvão de lenha não serão tratados no estudo por apresentarem processos artesanais e não ser um segmento profissionalizado. TOLEDO (2006) apresenta uma nova tecnologia na produção de carvão que pode profissionalizar a industria deste segmento.

\subsection{Levantamento dos dados e aplicação}

Para aplicação dos modelos será necessária coleta de dados de empresas dos três segmentos em estudo neste trabalho. Os dados agrupados forneceram um modelo econômico para cada um dos segmentos do setor de biocombustíveis. Um dos objetivos deste trabalho é a criação de um modelo econômico baseado nos dados coletados entre as empresas de cada segmento. Abaixo são apresentados os detalhes para cada um dos segmentos: 
- Biodiesel: o modelo foi baseado em projetos de empresas devido a fase embrionária do setor e o elevado número de empresas que estão sendo criados.

- Álcool: foram coletados dados contábeis de uma empresa instalada no estado de São Paulo. De posse destes dados, elaborou um modelo de negócio para teste dos métodos de avaliação de empresa;

\subsection{Estruturas da Dissertação}

O levantamento teórico necessário ao desenvolvimento do trabalho e a ferramenta do estudo proposto será abordada no Capítulo 2. Os modelos de avaliação serão detalhados nos seus fundamentos, funcionalidade, suas vantagens, suas limitações a aplicabilidade dos modelos no setor.

No Capitulo 3 será apresentado o setor de biomassa para fins energéticos. O setor será dividido nas principais indústrias: álcool, biodiesel, carvão vegetal e biogás para uma maior avaliação das suas principais características, potencial de crescimento.

No Capítulo 4 será aplicado o método de desconto de fluxo de caixa livre e o modelo de múltiplos para as empresas do segmento de biodiesel.

No Capítulo 5 será aplicado o método de desconto de fluxo de caixa livre e o modelo de múltiplos para as empresas do segmento de álcool.

No Capitulo 6 serão feitas considerações finais e indicações a trabalhos futuros. 


\section{REVISÃO TEÓRICA}

\subsection{O princípio de avaliação de empresas}

O valor de uma empresa se baseia na capacidade que ela tem para gerar fluxos de caixa e na incerteza a eles associadas (DAMODARAN, 2001).

Para empresas de tecnologia ou empresas de novos setores; o lucro negativo e a presença de ativos intangíveis são usados pelos analistas como motivos para o abandono de modelos tradicionais e para o desenvolvimento de novos métodos que possam ser usados para justificar o investimento neste tipo de empresas.

Ao analisar uma oportunidade de investimento, o investidor normalmente se depara com três fatores básicos que determinam à natureza do investimento: a irreversibilidade, a incerteza e o momento de investir, conforme explica DAMODARAN (2001).

- Irreversibilidade: o custo inicial do investimento é ao menos parcialmente perdido. Não se pode recuperar este investimento inicial caso haja mudança de idéia quanto a decisão de investir;

- Incerteza: quanto aos benefícios futuros do investimento. Na melhor das hipóteses podemse calcular as probabilidades dos resultados possíveis que podem gerar retornos maiores ou menores para o investimento;

- Momento de Investir: há certa liberdade quanto ao momento de investir. Pode-se adiar o investimento na espera de mais informação sobre o futuro (mas nunca, é claro, absoluta certeza).

As teorias tradicionais de avaliação parecem não ter reconhecido adequadamente as importantes implicações qualitativas e quantitativas que advém da interação destes três fatores. Um exemplo disso é o fato de que investimentos reais parecem ser muito menos sensíveis a mudanças pontuais nas taxas de juros ou de política tributária do que à volatilidade e à incerteza quanto ao ambiente econômico como um todo. 
Segundo CORNELL (1994), "o objetivo de uma avaliação é o de estimar o valor justo de mercado de uma empresa. O termo valoração refere-se o processo de estimar o preço pela qual uma propriedade trocaria de mão entre um comprador e um vendedor, estando ambos dispostos a fazer tal transação. Quando o ativo avaliado é uma empresa, a propriedade que o comprador e o vendedor hipotéticos estão negociando consiste nos direitos de todos os detentores de títulos da empresa, incluindo ações, títulos e dívidas privadas”.

NOGUEIRA (1999) destaca que "a avaliação de empresas, diferentemente de avaliação de quadros, pinturas e obras de arte, não deve se basear em percepções ou intuições, mas no conhecimento profundo tanto da própria empresa alvo quanto do mercado no qual está inserida. A determinação do valor de uma empresa é extremamente útil e quesito fundamental para a gestão de carteira de investimentos, análise de fusões e aquisições totais ou parciais, liquidações, abertura de capital e privatizações, além de feedback para gestores e proprietários de empresas sob o ponto de vista de eficiência da administração dos negócios”.

O valor justo de mercado é definido por HELFERT (2000) como: “o valor de qualquer ativo ou grupo de ativos quando comercializado em um mercado organizado ou entre partes privadas em uma transação espontânea, sem coerção".

\subsection{Principais metodologias de avaliação de empresas}

Inserida num contexto de crescente competitividade, a área de avaliação de empresas tornouse, nas últimas décadas, uma das mais importantes e palpitantes na comunidade financeira mundial. Diversos teóricos e analistas de mercado têm se dedicado amplamente ao desenvolvimento e aprimoramento de técnicas que possam avaliar, com a melhor precisão possível, o verdadeiro valor e as melhores escolhas de investir em empresas.

Dentre as diversas razões que justificam tal demanda por precisão estão a compra e a venda de negócios, a dissolução de sociedades e a liquidação de empreendimentos através de fusões e aquisições e privatizações. Ainda mais usual é a necessidade de avaliação para monitoramento das decisões de gestão, advinda da estrutura de mercado de capitais que normalmente separa a figura do acionista da do gestor (ou agente), sugerindo formas objetivas de controle e acompanhamento do trabalho desenvolvido pelos executivos na obtenção do valor mais alto possível para cada ação pertencente aos acionistas da companhia. 
Como regra geral, os indivíduos buscam tomar decisões de investimentos que maximizem sua satisfação ou consumo ao longo do tempo. Analogamente, as empresas preocupam-se em maximizar a riqueza de seus acionistas, ajudando-os a atingir o seu objetivo de consumo máximo.

Embora não conclusivos, os métodos de avaliação oferecem um importante instrumento para auxiliar aqueles que estão envolvidos num processo de avaliação de projetos, prestando-se, principalmente, como suporte a importantes decisões estratégicas, de fato, conforme DAMODARAN (1999), "o valor de uma empresa pode ser diretamente relacionado às decisões que torna - relativas a que projetos empreende, como os financia e sua política de dividendos. A compreensão deste relacionamento é a chave para a tomada de decisões que adicionam valor e reestruturação financeira sensata".

CORNELL (1994) identifica quatro modelos de avaliação de empresas bastante difundidos. São eles:

- a avaliação pelo valor de livro ajustado;

- a avaliação de ações e dívidas;

- a avaliação por múltiplos de mercado;

- a avaliação pelo fluxo de caixa descontado;

- opções reais.

Segundo DAMODARAN (2002), para avaliar uma empresa são necessárias algumas informações obtidas de três fontes distintas:

- Demonstrações contábeis da empresa: para determinar o resultado da empresa, o volume de faturamento, e fornecer a maior parte dos dados necessários para qualquer procedimento de avaliação de empresas;

- Histórico da Empresa: tanto em termos de lucro, quanto em preços de mercado, esse tipo de informação ajuda a determinar o nível de atividade e de ciclo de vida da empresa; 
- Setor econômico no qual a empresa atua: análise da concorrência em grupos de pares de empresas, para comparar a empresa aos seus concorrentes, em relação ao seu risco, retorno e crescimento em termos de fluxo de caixa.

\subsubsection{Valor Contábil}

O método mais simples para se determinar o valor de negociação de uma empresa é o método do valor contábil, também conhecido como valor de livro ajustado (adjusted book value), que se baseia na informação obtida a partir do balanço patrimonial da empresa.

CORNELL (1994) define o valor baseado neste método como sendo a soma dos valores de todas as exigibilidades que investidores tenham na empresa. Assim, o valor contábil pode ser obtido por dois métodos distintos. Primeiro método utiliza o somatório do valor de todas as ações, lucros acumulados, reservas e dívidas não operacionais de curto e longo prazo da empresa. Outro método é obtido a partir da diferença entre ativos totais líquidos e os passivos operacionais da empresa - excluindo-se dívidas não operacionais e compromissos da empresa com investidores e sócios.

Abaixo a figura, apresenta o valor de livro não ajustado da empresa.

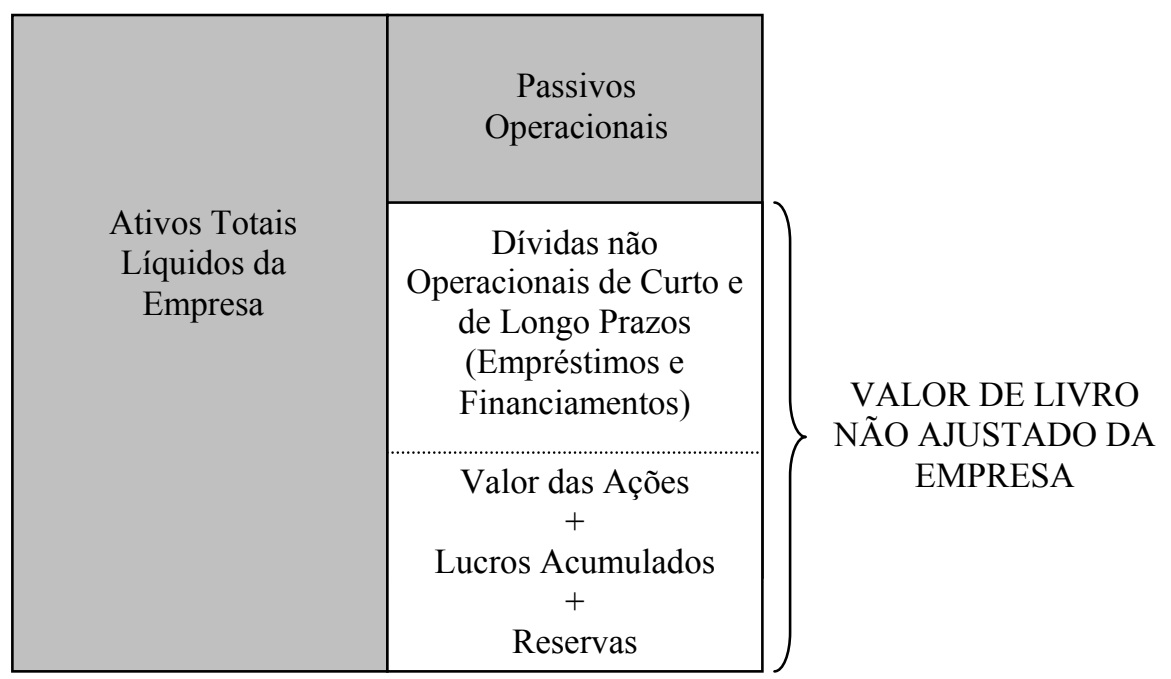

Figura 1: Valor de Livro não ajustado da empresa Fonte: CORNELL (1994)

A fragilidade do modelo baseado em balanços patrimoniais está baseada no fato de que os ativos e passivos reportados pelos contadores nesses demonstrativos podem não refletir seus reais valores de mercado. Como o valor contábil é baseado em custos históricos, deixa-se de levar em conta fatores como a inflação e a curva de obsolescência, o que leva a uma divergência entre o valor contábil e o valor de mercado. Além disso, há ativos valiosos que 
não são relacionados no balanço patrimonial, como o que CORNELL (1994) chama de capital organizacional. Segundo o autor, o capital organizacional representa o valor criado quando se reúne empregados, consumidores, fornecedores e gerentes em uma unidade coesa com relacionamento de longo prazo. Essa sinergia gera valor, que não é captado pelo valor contábil.

Ainda algumas limitações deste método, dentre elas: a não observância do custo de oportunidade do capital investido; a valoração baseada no principio contábil do custo histórico, que supõe a invariabilidade no tempo dos valores investidos; e a inobservância do horizonte do horizonte de resultados previstos posteriormente à data de avaliação.

Mesmo com tais limitações, nem sempre se faz abandonar o método do valor contábil. Há situações em que o valor contábil pode ser ajustado para que se aproxime do valor de mercado. CORNELL (1994) desenvolve dois métodos de ajustes, um deles substituindo o valor contábil dos ativos da empresa por seus custos de reposição e o outro método substituindo aqueles valores por estimativas do valor de liquidação dos ativos. Para isto leva em conta fatores como a inflação e a obsolescência, trazendo maior complexidade para o modelo e, portanto perdendo sua objetividade e simplicidade.

Este modelo como descrito nas limitações acima não é adequado ao cálculo do valor das empresas do setor de biocombustíveis. Um setor que se encontra em fase de expansão, em que as todas as contas do balanço variam de acordo com as oscilações do mercado, o modelo não satisfaz as exigências os investidores para avaliação do negócio.

\subsubsection{Modelo de desconto de dividendos}

DAMODARAN (2002) aponta, no processo de avaliação por desconto de dividendos, que o único fluxo de recurso disponível aos acionistas é a distribuição de dividendos. $\mathrm{O}$ valor $\mathrm{V}$ de uma empresa de uma empresa através do valor presente dos fluxos de dividendos, descontado por uma taxa de retorno exigida pelo acionista, como definido pela seguinte equação:

$V=\sum_{t=1}^{\infty} \frac{D i v_{t}}{\left(1+k_{e}\right)^{t}}$

Equação 1

Sendo:

$t$ : prazo até o pagamento do dividendo; 
$\operatorname{Div}_{t}$ : valor do pagamento de dividendos no tempo $t$;

$k_{e}$ : taxa de retorno exigida pelo acionista.

Ao analisar o caso no qual uma empresa possui taxa de crescimento de dividendos infinita, COPELAND e WESTON (1999) sugerem o uso do modelo de crescimento constante, considerando que nem todo dividendo é distribuído e existe uma fração de reinvestimento na empresa, perpétua. Desta forma resolve um problema importante na avaliação de perpetuidade de um fluxo de recebimento por parte do acionista.

Para o cálculo do valor da empresa, dado um modelo constante dos dividendos, utiliza-se o modelo de GORDON (1962). Podendo ser calculado o valor do fluxo de dividendos descontado utilizando a fórmula de crescimento perpétuo, de acordo com a seguinte equação:

$$
V=\frac{D i v_{1}}{\left(k_{e}-g\right)}
$$

Sendo:

$D i v_{1}$ : valor do pagamento de dividendos no próximo exercício;

g: taxa de crescimento constante no pagamento de dividendos, que deve ser menor que $K_{e}$. Apesar da praticidade e simplicidade do cálculo do valor da empresa baseado na dividendos, requer alguns conhecimentos prévios do analista citados no final do tópico por DAMODARAN (2002). A projeção do fluxo de caixa para não parecer uma previsão, requer o uso de todo ferramental a disposição das outras ciências para a área de finanças. $\mathrm{O}$ cálculo do valor da empresa utilizando este método e outros que exigem projeções é uma arte.

Podemos dividir a projeção do dividendo de forma passiva ou ativa.

- A forma passiva requer a projeção dos parâmetros que irão compor o dividendo, ou seja, estando a empresa em condições normais de mercado, o qual este dita os parâmetros associados a empresa como a participação do mercado, previsão de faturamento relacionado ao binômio preço - quantidade, valor de mão de obra, incentivos, etc.

- Na forma ativa o acionista interfere nos parâmetros da empresa de forma indireta, determinando o valor da sua expectativa de maximização dos resultados esperados. 
Isso interfere nos parâmetros dos negócios, ficando a cardo dos administradores atenderem estas necessidades.

As limitações do uso deste modelo são evidentes, pois tratando de um setor ainda fechado para o mercado de capitais, cuja representação e falta de dados disponíveis no mercado tornam o acesso à distribuição de dividendos ainda precários.

\subsubsection{Método de Fluxo de Caixa Descontado (DCF $)^{1}$}

Este método é o mais conhecido e mais utilizado pelos acadêmicos e analistas para o cálculo do valor a empresa. A citação deste método apresentado em quase todos os trabalhos cujo tema é avaliação de empresas. Este método pode ser aplicado a praticamente qualquer situação, bastando projetar os fluxos de caixa da empresa.

Esse método consiste em estabelecer um conjunto de premissas operacionais que são utilizadas para calcular os resultados futuros da empresa por um determinado período, de modo a obter o valor dos fluxos de caixa futuros esperados. $\mathrm{O}$ valor da empresa é então igual à soma dos valores presentes dos fluxos de caixa previstos (após o imposto de renda).

Os fluxos de caixa são obtidos mediante uma projeção de resultados operacionais, levando-se também em consideração os investimentos necessários em capital de giro e em ativo permanente. Em outras palavras, esses fluxos de caixa são uma retirada (eventualmente fictícia) de dividendos, até o máximo permitido pelo equilíbrio financeiro da empresa. O valor presente é calculado a partir de uma taxa de desconto que remunere adequadamente o capital de um investidor, tendo em conta os riscos específicos do negócio.

O DCF foi apresentado pela primeira vez em um trabalho intitulado "Dividend policy, growth and the valuation os shares" por MILLER e MODIGLIANI (1961). Desde este trabalho, diversas variantes da metodologia proposta forma surgindo, mantendo, porém as características essenciais.

COPELAND, KOLLER E MURRIN (2002) define o fluxo de caixa descontado: "o valor acionário de uma empresa como sendo o valor de suas operações (valor empresarial

\footnotetext{
${ }^{1}$ Discounted Cash Flow
} 
disponível para todos os investidores) menos o valor do endividamento e outras formas de passivo de prioridade superior a do capital ordinário".

COPELAND (1994) destaca que este método "é o melhor porque é o único dos métodos de avaliação que exige informações completas da empresa" Intuitivamente o valor da empresa de ser uma função de três variáveis: o volume de fluxos de caixa que gera o momento em que estes fluxos de caixa se darão e a incertezas a eles associada. A avaliação pelo fluxo de caixa descontado reúne esta três variáveis.

Segundo DAMODARAN (1997) este método procura determinar o valor da empresa com base na capacidade de remunerar seus acionistas no longo prazo, através dos fluxos de caixa futuros esperados para a empresa. Um ponto chave, que permite a escolha deste método como sendo o mais importantes entre todos é o fato de explicitar as variáveis chaves para a formação do valor da avaliação e permitir a simulação dos mais diferentes cenários e premissas macroeconômicas, estratégicas, operacionais e financeiras.

A projeção das variáveis exige do responsável o mais amplo possível conhecimento da empresa, do mercado de atuação e as características fundamentais do setor. O método fornece um valor baseado nas premissas dos parâmetros que devem estar alinhados ao valor da empresa, ou seja, a sua fidelidade com o valor da empresa está relacionada com os números que serão utilizados como parâmetros no modelo e para isso não existe nenhum método para o seu levantamento.

DAMODARAN (1997) apresenta casos em que o DCF encontra dificuldades, descritos abaixo:

- Empresas em dificuldade financeiras: empresas nessa situação possuem fluxos de caixa negativos e não existe uma expectativa de receita a curto prazo;

- Empresas cíclicas: para essas empresas os fluxos de caixa futuro esperado geralmente são uniformizados, por seguirem a economia aumentando em momentos positivos e diminuindo em momentos de recessão;

- Empresas com ativos não utilizados: se a empresa possuir ativos não utilizados, estes obviamente não geram fluxos de caixa, conseqüentemente não estarão refletidos no fluxo de caixa descontado. Esse problema poderá ser superável através da obtenção 
de seu valor externamente e somado ao valor obtido através da avaliação pelo fluxo de caixa descontado;

- Empresas com patentes ou opções de produtos: essas patentes e opções de produtos não utilizados que geram fluxos de caixa atuais, e nem será gerado num futuro próximo, possuem um valor. Como no item anterior, esses ativos poderão ser avaliados no mercado livre, ou através da utilização de modelos de precificação de opções, e somando-se o valor obtido ao resultado de avaliação pelos fluxos de caixa descontados;

- Empresas em processo de reestruturação: a empresa, quando nessa situação, resulta em grandes modificações nas políticas financeiras e de investimentos, o que pode distorcer radicalmente os dados históricos e, conseqüentemente, distorcer o valor da empresa. Mesmo assim, essas empresas podem ser avaliadas, se os fluxos de caixa futuros refletirem os novos negócios e o risco financeiro da empresa;

- Empresas envolvidas em aquisições: deve-se observar em primeiro lugar se existe sinergia entre as empresas fusionadas, e se podem ser estimados os seus valores. Em segundo lugar, os efeitos exercidos pela mudança de gerência sobre o fluxo de caixa e risco;

- Empresas de capital fechado: o maior problema está na medição de risco - para utilização na estimativa de taxas de desconto -, sendo que a maioria dos modelos de risco/retorno exigem que os parâmetros de risco sejam estimados a partir dos preços históricos, e que os títulos dessas empresas não sejam negociados. Aqui vale a comparação com empresas semelhantes, mas de capital aberto, com ações negociadas em bolsa.

Esse método consiste em estabelecer um conjunto de premissas operacionais que são utilizadas para calcular os resultados futuros da empresa por um determinado período, de modo a obter o valor dos fluxos de caixa futuros esperados. O valor da empresa é então igual à soma dos valores presentes dos fluxos de caixa previstos (após o imposto de renda).

Os fluxos de caixa são obtidos mediante uma projeção de resultados operacionais, levando-se também em consideração os investimentos necessários em capital de giro e em ativo permanente. Em outras palavras, esses fluxos de caixa são uma retirada (eventualmente 
fictícia) de dividendos, até o máximo permitido pelo equilíbrio financeiro da empresa. O valor presente é calculado a partir de uma taxa de desconto que remunere adequadamente o capital de um investidor, tendo em conta os riscos específicos do negócio.

\subsubsection{Componentes da metodologia do Fluxo de Caixa Descontado}

A aplicação deste método exige a determinação de três componentes básicos que por sua vez canalizam todos os parâmetros da empresa. Estes componentes refletem todos os números do negócio e a partir daí podem ser facilmente calculados. Fazem parte destes componentes: o fluxo de caixa projetado, o valor residual e a taxa de desconto.

\section{Fluxo de Caixa}

A projeção do Fluxo de Caixa é determinada a parti dos modelos de simulação aplicáveis a empresa. Esses modelos levam em conta as variáveis de natureza econômico-financeira que têm maior impacto na formação dos fluxos de caixa futuros (vendas, margens, estrutura de custos, necessidades de investimentos, etc).

O fluxo de caixa livre para o acionista pode ser calculado, de forma simplificada, partindo da demonstração de resultados projetada da empresa, de acordo com o seguinte quadro: 


\begin{tabular}{|ll|}
\hline \multicolumn{1}{|c|}{ Fluxo de Caixa Livre } \\
\hline$(+)$ & Lucro antes de juros, impostos, depreciação e amortização \\
$(-)$ & Impostos \\
$(=)$ & Lucro Líquido operacional menos impostos ajustados \\
$(+)$ & Depreciação e amortização \\
$(=)$ & Fluxo de caixa bruto \\
$(-)$ & Mudanças do capital de giro \\
$(-)$ & Investimentos no ativo fixo \\
$(-)$ & Aumento líquido de outros ativos \\
$(=)$ & Fluxo de caixa operacional livre \\
$(+)$ & Fluxo de caixa de investimetos não operacionais \\
$(+)$ & Receita de juros depois dos impostos \\
$(+)$ & Diminuição de títulos negociáveis \\
\hline$(=)$ & Fluxo de Caixa Livre (CF $)$ \\
\hline
\end{tabular}

Tabela 1: Elaboração do Fluxo de Caixa Livre $(C F)$ Fonte: COPELAND, KOLLER e MURRIN (2002).

Segundo DAMODARAN (2002), a determinação da taxa de crescimento dos fluxos de caixa de uma empresa depende do setor econômico no qual ela está inserida, o que irá determinar, de forma relativa, qual será o nível de crescimento, tanto em termos de faturamento, lucratividade, quanto em termos de fluxo de caixa e dividendos.

O horizonte de projeções utilizado pelo modelo é um prazo suficientemente longo para que os fluxos de caixa se estabilizem após os efeitos das mudanças em andamento na empresa. As variáveis a serem utilizadas pelo modelo são aquelas que afetam de maneira mais direta o resultado da empresa e cuja variação é mais sensível. Essas variações fornecem informações suficientemente detalhadas para garantir a validade das conclusões alcançadas. Por essa razão, tais variáveis são denominadas value drivers ou direcionadoras de valor.

\section{$\underline{\text { Taxa de Desconto }}$}

O ponto crítico para o cálculo do DCF (Disconted Cash Flow) está na escolha da taxa de desconto mais adequada, estas por sua vez são influenciadas pelo nível de risco. As premissas adotadas para o cálculo do fluxo de caixa futuro geram um grau de incerteza, pois são dados 
gerados baseados no passado, gerando risco do negócio e conseqüentemente o valor da empresa tende a não ter um consenso matemático.

Quanto mais distantes forem os horizontes de previsão, maior será o grau de incerteza, uma vez que estes fluxos são diretamente influenciados pelas vendas futuras, custos em geral, taxas de juros, câmbio, políticas governamentais, aspectos climáticos, mudanças demográficas, políticas internacionais, gostos dos consumidores, novas tecnologias, entre outras.

Utiliza-se no método o Custo Médio Ponderado de Capital (Weighted Average Cost of Capital - WACC) que calcula o custo de oportunidade tanto para os acionistas e o custo de capital de terceiros, proporcionalmente à participação na estrutura de capital na empresa.

\section{$\underline{\text { Valor Residual }}$}

Em tese, pelo menos, as empresas podem ter vidas infinitas. Como não é possível estimar os fluxos de caixa no infinito, geralmente se impõe um fechamento à avaliação pelo fluxo de caixa interrompendo a estimativa dos fluxos de caixa em algum ponto do futuro e calculando um valor final que reflita o valor da empresa naquele momento.

Os acionistas podem esperar obter com a alienação das ações no final do horizonte de projeções adotado. Neste momento assume um taxa de crescimento constante do negócio a partir do momento em que se estabelece um estado de equilíbrio na projeção dos fluxos de caixa.

\subsubsection{Cálculo do valor pelo método DCF}

O valor da empresa para o acionista, de acordo com COPELAND, KOLLER E MURIN (2002), "é o seu valor operacional mais ativos não-operacionais, tais como investimentos em empresas não correlatas e não consolidadas, menos o valor do seu endividamento e qualquer passivo operacional". De maneira mais simplificada, seria equivalente a dizer que o valor da empresa é igual ao valor presente do fluxo de caixa operacional projetado e descontado pelo $W A C C$, subtraído pelo valor de mercado de dívidas da empresa. 


\section{Segundo DAMODARAN (1997):}

"Existem dois caminhos para a avaliação por fluxo de caixa descontado: o primeiro é avaliar apenas a participação acionária do negócio, enquanto o segundo é avaliar a empresa como um todo, que inclui, além da participação acionária, a participação dos demais detentores de direitos na empresa. Embora ambas as abordagens descontem fluxos de caixa a taxas de desconto relevantes são diferentes em cada caminho.”

Avaliar a empresa com base na projeção do fluxo de caixa e o valor residual requer uma atenção importante. Os parâmetros para o cálculo do fluxo de caixa ao longo do tempo podem se tornar imprecisos e escassos, prejudicando a formação da projeção do fluxo de caixa ao longo do tempo. Torna-se necessário o uso do valor residual com cautela, pois a taxa de crescimento pode não ter sido estimada com cuidado, aumentando assim os erros na previsão no valor residual.

A segunda parte da estimativa dos fluxos de caixa, período no qual as previsões são incertas, pode ser calculada como no modelo de dividendos, com a utilização do modelo de perpetuidade sugerido por GORDON (1962), que supõe um crescimento g constante e infinito dos fluxos de caixa da empresa.

Isso pode ser demonstrado na formula abaixo:

$V=\sum_{t=1}^{t=n} \frac{C F_{t}}{\left(1+k_{c}\right)^{t}}+\frac{C F_{t+1}}{\left(k_{c}-g\right)\left(1+k_{c}\right)^{n+1}} \quad$ Equação 3

Sendo:

$k_{c}$ : taxa de desconto;

g: taxa de crescimento constante no pagamento de dividendos, que deve ser menor que $K_{c}$.

$t$ : prazo referente aos períodos de previsão do fluxo de caixa;

$C F_{t}$ : valor do fluxo de caixa gerado pela empresa no tempo $t$;

$n$ : término da previsão do fluxo de caixa da empresa.

Na projeção do componente "g" e dos parâmetros do $C F$ será visto em um dos tópicos em um item abaixo os diferentes modelos de projeções propostos. 
COPELAND, KOLLER e MURRIN (2002) afirmam que o valor operacional de uma empresa é igual ao valor descontado do fluxo de caixa livre futuro esperado por uma taxa ajustada ao risco da empresa. Segundo os autores citados: "o custo de oportunidade de todos os provedores de capital, ponderado por sua contribuição relativa para o capital total da empresa", denominada custo médio ponderado de capital - WACC. Adaptando a formula acima, temos:

$V=\sum_{t=1}^{t=n} \frac{C F_{t}}{(1+W A C C)^{t}}+\frac{C F_{t+1}}{(W A C C-g)(1+W A C C)^{n+1}}$

Equação 4

Sendo:

$W A C C$ : custo médio ponderado de capital;

$g$ : taxa de crescimento constante no pagamento de dividendos, que deve ser menor que $K_{c}$;

$t$ : prazo referente aos períodos de previsão do fluxo de caixa;

$C F_{t}$ : valor do fluxo de caixa gerado pela empresa no tempo $t$;

$n$ : término da previsão do fluxo de caixa da empresa.

No setor de biocombustíveis dado o fato dos produtos se comportarem como commodities, a projeção dos parâmetros para determinação dos dividendos torna-se uma tarefa voltada para no binômio preço - quantidade especificamente no preço, pois a quantidade vendida está relacionada diretamente com o investimento inicial, cujo valor irá determinar uma capacidade instalada constante, caso não seja realizado investimentos para expansão.

Neste setor ainda embrionário para o mercado de capitais, estimar os parâmetros do mercado como taxa de desconto sem o respaldo de empresas de capital aberto, torna-se uma tarefa difícil, porém é possível apresentar uma metodologia que associe ente setor com outros setores, cujos fatores de riscos são similares, proposto no Capitulo 4 no caso prático.

DAMODARAN (2001) aponta que muitos críticos dos modelos de desconto de fluxo de caixa para avaliação de empresas, sustentam a impossibilidade deste último modelo não refletir, por exemplo, o fato de empresas iniciantes em um mercado de grande porte pode deixar de refletir a possibilidade, por menor que seja, de que essa empresa se destaque das demais. Da mesma forma, as empresas que detêm patentes ou licença de uso exclusivo de um produto, além disso, empresas em um setor estruturado que apresentam grande diferencial. O modelo DCF 
subestima o valor da empresa, porque desconsideram as opções que as empresas têm de investir mais no futuro e aproveitar sucessos inesperados na suas atividades.

\subsubsection{Custo ponderado de capital}

COPELAND, KOLLER e WESTON (2002) definem o WACC com "a taxa de desconto, ou valor do dinheiro no tempo, usada para converter o fluxo de caixa livre futuro $(C F)$ em valor presente para todos os investidores". No final da década de 90, o mercado comprador deu importância para a estimativa correta do custo de capital, relacionado com o aumento de volatilidade nos mercados e a globalização do sistema financeiro.

Os autores ainda ressaltam que a estimativa do custo de capital deve:

- Compreender uma média ponderada dos custos de todas as fontes de capital, ou seja, endividamento, capital social, etc, uma vez que o fluxo de caixa livre representa o caixa disponível para todos os agentes fornecedores do capital.

- Ser computada após os impostos, uma vez que o fluxo e caixa livre são calculados após os impostos.

- Utilizar taxas nominais de retorno construídas a partir das taxas reais de inflação prevista, já que o fluxo de caixa livre de previsto é expresso em termos nominais.

- Ajustar para o risco sistêmico suportado por cada fornecedor de capital, uma vez que cada um deles espera um retorno que remunera o risco assumido.

- Empregar as ponderações de valor de mercado para cada elemento de financiamento, pois este reflete os reais efeitos econômicos de cada tipo de financiamento, ao passo que os valores escriturais não costumam fazê-lo.

- Esta sujeita a mudanças durante o período de previsão do fluxo de caixa, por causa de mudanças previstas da inflação, do risco sistêmico ou da estrutura de capital.

Para o cálculo do custo de capital de terceiros utiliza o próprio custo de captação, pois este reflete o risco associado ao mercado de títulos. Já o custo de capital de terceiros exige o uso de ferramentas de análise que podem ser o modelo de desconto de dividendos, CAPM (Capital Asset Price Model) e APT (Arbitrage Pricing Theory). 
Abaixo, MODIGLIANI \& MILLER(1968) propõe uma expressão para o cálculo da taxa de desconto. Lembrando que esta taxa pode variar ao longo do tempo.

$$
W A C C=k_{d}(1-t) \frac{D}{D+E}+k_{e} \frac{E}{D+E} \quad \text { Equação } 5
$$

Sendo:

$t$ : imposto de renda;

$k_{d}$ : custo de endividamento a mercado;

$k_{e}$ : custo de capital próprio da empresa;

$D$ : o valor de mercado das dívidas;

$E$ : valor de mercado das ações da empresa.

É consenso na literatura financeira sobre a necessidade de retorno esperado de um ativo ser proporcional ao seu risco, pois os investidores somente assumirão riscos adicionais se forem compensados de forma conveniente. As discussões sobre o qual a medida relevante de risco e qual a forma correta de traduzir esta medida em acréscimo de retorno, no entanto, estão longe de convergirem para uma única explicação.

Entre os diversos modelos utilizados, o Capital Asset Pricing Model (CAPM) - desenvolvido por SHARPE (1970) - é o padrão usado por diversos autores. Este modelo possui as vantagens de ser simples e intuitivo, além de ser facilmente aplicável.

O CAPM propõe uma formulação na qual o risco de um ativo é decomposto em um fator que depende do mercado como um todo (risco sistêmico, mensurado através do índice beta) e uma parcela referente apenas ao risco próprio inerente ao ativo.

O CAPM propõe que apenas a parcela ao risco de mercado deve ser recompensada, pois, como demonstra a Moderna Teoria do Portfolios, o risco próprio dos ativos pode ser eliminado em uma carteira através da diversificação. A equação do modelo de SHARPE (1970), que mostra a relação entre o retorno do ativo e seu risco sistêmico.

$$
k_{S}=r_{f}+\beta\left(E\left[r_{m}\right]-r_{f}\right) \quad \text { Equação } 6
$$


Sendo:

$k_{s}$ : retorno médio do ativo ou custo de capital;

$\beta$ : coeficiente do risco sistêmico;

$E\left[r_{m}\right]$ : esperança do retorno médio do mercado;

$r_{f}$ : taxa livre de risco do pais.

Analisando esta equação, percebemos a necessidade de estimar o beta do ativo, que em certos casos traz uma considerável dificuldade. Ele mede a tendência de variação de uma ação em relação ao mercado.

Estatisticamente, o beta é calculado dividindo-se a covariância entre o retorno do título individual e o retorno do índice de mercado pela variância do retorno do índice de mercado, conforme mostra a Equação abaixo:

$$
\beta_{a}=\frac{\operatorname{Cov}\left(r_{a}, r_{m}\right)}{S^{2}\left(r_{m}\right)}
$$

Sendo:

$$
\begin{aligned}
& \beta_{a}: \text { índice Beta do ativo em estudo; } \\
& r_{a}: \text { retorno do ativo em estudo; } \\
& r_{m} \text { : retorno médio do mercado; } \\
& \text { Cov }\left(r_{a}, r_{m}\right) \text { : covariância entre } \mathrm{r}_{\mathrm{a}}, \mathrm{r}_{\mathrm{m}} ; \\
& S^{2}\left(r_{m}\right): \text { variância do retorno do índice de mercado. }
\end{aligned}
$$

Conforme DAMODARAN (1997) o beta de uma empresa é influenciado por três variáveis básicas:

- Tipo de negócio: quanto maior a sensibilidade do tipo de negócio às condições de mercado, mas alto será o beta. 
- Alavancagem operacional: empresas com alto grau de alavancagem operacional apresentam maiores variabilidades nos lucros antes dos juros e impostos do que as empresas que oferecem serviços semelhantes com baixo grau de alavancagem operacional. Deste modo, se as outras condições permanecem inalteradas, as empresas menos alavancadas tendem a apresentar menores oscilações nos fluxos de caixa disponíveis aos seus acionistas, resultando em betas menores.

- Alavancagem Financeira: empresas mais alavancadas financeiramente tendem a apresentar betas maiores, pois, sendo os juros sobre o capital de terceiros equivalentes a custos fixos, estes permitem um incremento mais que proporcional dos lucros nos anos bons e uma queda mais acentuada nos anos ruins, aumentando assim a variabilidade de seus retornos.

Da definição, vemos que a abordagem mais consistente para a estimativa dos betas requer preços de mercado para o ativo a ser avaliado, o que impossibilita sua aplicação a ações não negociadas e pouco líquidas ou empresas de capital fechado. Quando for o caso, DAMODARAN (1997) sugere a adoção de betas de empresas de capital aberto com ações regularmente negociadas em bolsa que sejam comparáveis em termos de risco de negócios e alavancagem.

\subsubsection{Ciclo de vida da empresa}

DAMODARAN (2001) fornece um panorama do ciclo de vida de uma empresa e de como a disponibilidade de informações e a fonte de valor mudam no decorrer deste ciclo.

- Iniciantes: representa o primeiro estágio após a fundação de uma empresa. O produto carece de teste e não tem um mercado estabelecido. $\mathrm{O}$ valor desta empresa depende exclusivamente de seu potencial de crescimento futuro. Os dados precisam ser estimados dando margens a erros significativos. Estão baseados na competência de administradores e de sua capacidade para converter uma idéia promissora em um sucesso comercial.

- Expansão: já estabelecido sucesso comercial e estabelecimento da sua presença no mercado. As operações atuais da empresa fornecem parâmetros para precificação, margens e crescimento previsto, mas as margens atuais não podem ser projetadas para o futuro. 
- Alto crescimento: neste estágio as receitas crescem rapidamente, mas os lucros não acompanham. Nesta etapa, tanto as operações atuais quanto o histórico operacional da empresa contêm informações que podem ser usadas em sua avaliação. O número de empresas comparáveis costuma atingir seu pico neste estágio e essas empresas são bastante diversas nos seus estágios de desenvolvimento, indo de pequenos concorrentes de alto crescimento a outros maiores e de crescimento mais lento. Os ativos da empresa têm valor considerável, mas a maior parte do valor ainda deve ao crescimento futuro.

- Crescimento Maduro: à medida que o crescimento começa a se estabilizar, as empresas geralmente experimentam dois fenômenos. Os lucros e os fluxos de caixas costumam se elevar rapidamente, refletindo os investimentos realizados no passado e diminuí a necessidade em novos projetos. Nesse estágio de desenvolvimento, as empresas têm operações atuais que são indicativas do futuro, um histórico operacional que oferece muitas informações sobre o mercado em que opera e um grande número de empresas comparáveis no mesmo estágio. Os ativos contribuem tanto - ou mais para o valor das empresas do que a expectativa de crescimento e os dados da avaliação provavelmente serão estáveis.

- Declínio: o último estágio do ciclo de vida é o declínio. As empresas que se encontram nesse estágio percebem que suas receitas e seus lucros começam a cair, à medida que suas atividades amadurecem e novos concorrentes começam a ultrapassálas. Os investimentos existentes provavelmente continuarão a produzir fluxos de caixa, ainda que um ritmo menos acelerado, e a empresa terá pouca necessidade de investimentos. Assim seu valor dependerá inteiramente dos ativos existentes. O número de empresas comparáveis tende a decair nesta etapa e, provavelmente, todas estarão nas fases de crescimento maduro e declínio.

As empresas podem estar em diferentes estágios do ciclo de vida e desta forma um panorama do setor contribui para dimensionar os diferentes estágios que ainda estão por vir. Neste aspecto, podemos dividir a projeção de fluxo de caixa livre nos horizontes propostos por DAMODARAN (2001). Estes horizontes podem ser verificados na figura abaixo: 
Figura 2: Curva de maturidade de uma empresa genérica.

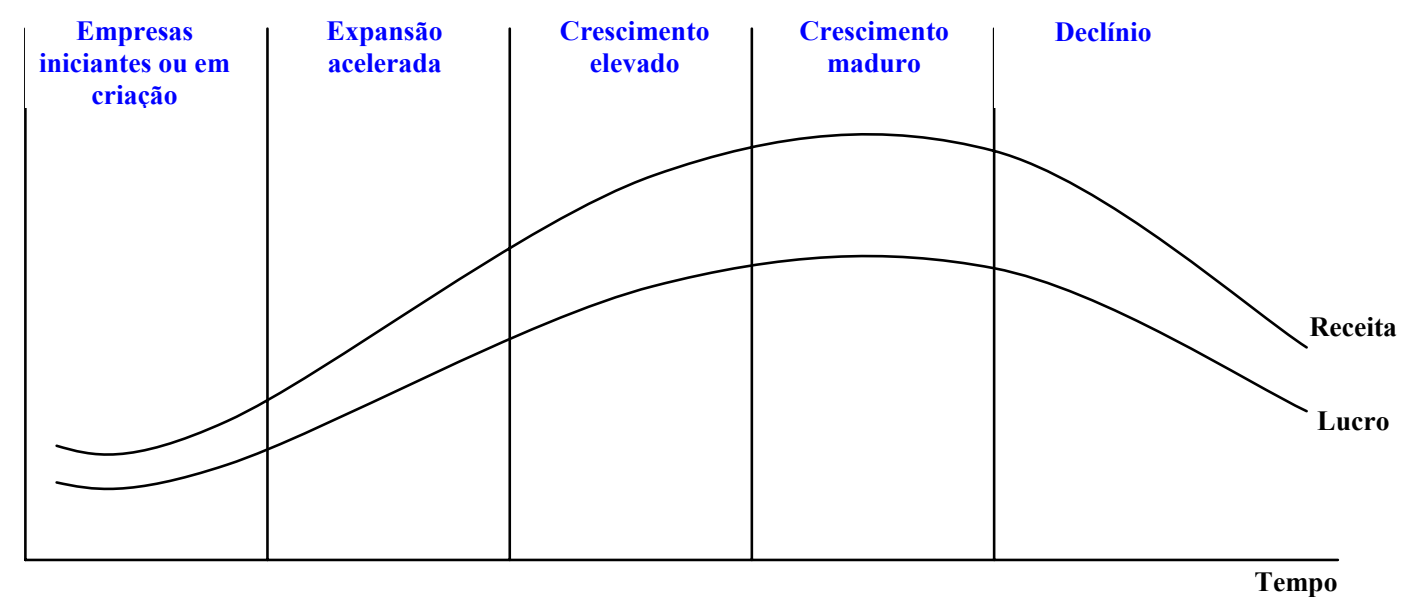

Fonte: Autor

NOGUEIRA (1999) cita cinco formas simplificadoras de projeções e suas respectivas deduções matemáticas, assim denominadas:

- Modelo de crescimento nulo, no qual os fluxos de caixa mantêm-se constantes infinitamente.

- Modelo de crescimento constante e não nulos dos fluxos, onde os fluxos crescem infinitamente a uma taxa constante, conhecida como modelo de Gordon;

- Modelo com dois períodos de crescimento, caracterizado por duas fases de projeções: no primeiro período adota-se um crescimento constante não nulo dos fluxos ou projetam-se explicitamente todos os fluxos, e no segundo período adota-se um crescimento infinito dos fluxos, nulo ou não nulo;

- Modelo H, derivado do modelo de dois períodos de crescimento, onde no primeiro supõe-se uma taxa de crescimento não constante, mas que diminui linearmente ao longo do tempo até atingir a taxa de crescimento estável no estado estacionário;

- Modelo com três ou mais períodos de crescimento, uma generalização do modelo de dois períodos.

O autor comenta o fato do crescimento nulo dos fluxos não espelha a realidade e não recomenda o seu uso devido a taxa de crescimento da economia. Defende o modelo de crescimento constante e não nulos dos fluxos (Modelo de Gordon) para empresas que já apresentam números constantes e taxas estáveis, taxas estas que não podem ser 
significativamente maiores. Mesmo assim esta projeção é o estado da arte da avaliação de empresas, pois mesmo de posse destes dados, o erro embutido aumenta consideravelmente no longo prazo.

Uma forma de minimizar erros na projeção do fluxo de caixa é abandonar a avaliação determinística e adotar cenários probabilísticos para os value drivers e suas inter-relações. Desta forma, uma faixa de valores possíveis da empresa com um grau de confiança torna-se um ferramental importante para o cálculo do valor da empresa.

O modelo com dois períodos de crescimento é indicado para empresas ainda não estabilizadas, onde é possível explicar os fluxos ou para aqueles que apresentem expectativas de alto crescimento inicial e que depois tendam a estabilizar-se em uma taxa de crescimento constante. Uma das limitações do modelo é a brusca mudança de taxas de crescimento quando se passa do primeiro para o segundo período de crescimento.

A limitação do modelo de dois períodos é corrigida pelo modelo H. Segundo DAMODARAN (2001) "o modelo H apresenta dois estágios para o crescimento, mas diferentemente do modelo clássico de dois estágios, na fase de crescimento inicial a taxa de crescimento não é constante, mas diminui linearmente ao longo do tempo até atingir a taxa de crescimento estável no estado estacionário".

Quanto ao último modelo abordado, com três ou mais períodos de crescimento, o mesmo nada mais é do que uma generalização dos modelos anteriores. Cabe ao analista ter o discernimento na escolha do modelo que mais convém para a empresa em estudo.

No setor de biomassa apesar das empresas aparentemente estarem posicionadas no estágio de crescimento maduro, as perspectivas que se iniciam com a inserção deste setor no mundo apresentam fases de expansão acelerada e crescimento elevado. Além disso, com a introdução de novas tecnologias no processo irá permitir ganhos de Know-how diferenciados. A perspectiva de ganhos futuros, desenvolvimento de novas tecnologias, introdução de novos mercados e abertura para o mercado de capitais transformarão as empresas deste setor em empresas com características de empresas da nova economia.

O setor de biomassa para fins energéticos (setor de agroenergia) encontra-se num estágio embrionário no mercado de capitais. Atualmente, encontram-se listadas na Bovespa apenas duas empresas deste setor em dois dos segmentos: 
- Álcool: Grupo Cosan - abertura do capital em 2004;

- $\quad$ Biodiesel: Ecodiesel - abertura em outubro de 2006;

- $\quad$ Carvão Vegetal - não existe nenhuma empresa listada na bolsa.

A estimativa de alguns dos importantes fatores para o cálculo do modelo DCF podem ser listados abaixo:

\section{Segmento Álcool}

O setor iniciou suas atividades na década de 80 com a crise do petróleo, passou por estágio de expansão entre os anos 80 e inicio dos anos 90, em meados dos anos 90 houve um declínio na produção do álcool e desde o inicio deste século o setor vem recebendo atenção com a introdução dos carros bicombustíveis e abertura de mercado em outros países.

Este segmento de biocombustíveis apresenta uma previsibilidade de crescimento atrelada ao aumento da frota de veículos e pode ter um crescimento ainda maior nos próximos anos com o aumento da exportação. Estas fases de crescimentos têm impacto direto no preço do álcool que vem sofrendo aumentos consideráveis, hoje de certa forma controlado pelo binômio preço álcool-gasolina, mas que pode ter impacto acentuado quando adicionado o fator exportação, obrigando o governo a criar uma política de preços subsidiado num futuro próximo.

A capacidade de uma usina de álcool nasce no momento da construção, ou seja, aumentos de capacidade ao longo da sua vida ocorrem apenas com novos investimentos e/ou capacitação para a hidrólise do bagaço, tecnologia desenvolvida pela empresa de máquinas brasileira Dedini. Portanto, a capacidade futura de produção de álcool de uma determinada usina está condicionada apenas ao binômio álcool/açúcar da sua criação, desde que não ultrapasse mais que 5 anos, pois as novas tecnologias têm provocado aumentos significativos neste período de tempo.

O segmento por apresentar apenas uma empresa de baixa liquidez no mercado de capitais nacional e não ser possível encontrar empresas em outros mercados, dificulta a escolha do beta mais apropriada para este segmento.

\section{Segmento Biodiesel}


Este setor encontra-se num estágio similar ao álcool nos anos 80 com a introdução do Proálcool, ou seja, expansão previsível para os próximos anos, pois o governo apresentou metas de adição de biodiesel ao diesel consumido no Brasil - 2\% de biodiesel em todo o diesel consumido no Brasil até início de 2008. Da mesma forma que o álcool, uma usina deste segmento oferece uma capacidade de produção de biodiesel constante ao longo do tempo, portanto os dois fatores principais preço e produção estão pré-definidos para os próximos anos. Porem, os principais insumos para este setor que são o álcool e os óleos (mamona, soja) por servirem de insumos para outras aplicações, podem sofrer impactos de demanda e conseqüentemente preços, impactando a margem e o fluxo de caixa.

O beta deverá ser estimado baseado em premissas de outros setores, pois a única empresa deste segmento abriu o capital em 2006 e não existe fonte de dados em outros países.

\section{Segmento Carvão Vegetal}

De todos os segmentos de biocombustíveis, o carvão vegetal é o que apresenta maior imprevisibilidade, pois está condicionado a diversos fatores cujo impacto pode influenciar fortemente a curva de crescimento dos últimos anos. O Brasil vem recebendo investimentos no setor siderúrgico, cujo mercado é o principal player mundial do uso de carvão vegetal siderúrgico, consolidando como um dos principais produtores mundiais de aço.

Não bastasse a expansão da siderurgia brasileira, o carvão vegetal não consegue atender o crescimento do setor e vem passando por transformações tecnológicas para garantir o abastecimento deste insumo e cada vez mais influenciar a relação do binômio carvão mineral e carvão vegetal.

Algumas questões ambientais, sociais e preço do carvão mineral forçaram os produtores de carvão vegetal a investirem em novas tecnologias já disponíveis no mercado. Com o mercado ofertado os produtores de aço converterão parte dos alto-fornos para o uso do carvão vegetal.

No Congresso sobre redução do ferro gusa em 2006, foram apresentadas diversas soluções para a expansão do uso do carvão vegetal no Brasil, mostrando a preocupação dos grandes produtores de inox (Acesita), tubos (V\&M) e produtores de ferro gusa. 


\subsubsection{Avaliação Relativa de Múltiplos}

De acordo com DAMODARAN (2002), a avaliação relativa tem por objetivo avaliar os ativos com base na precificação de outros ativos semelhantes no mercado. Abrange dois componentes: o primeiro é o fato de que os preços precisam ser padronizados, geralmente convertendo-os em múltiplos de lucros, valores escriturais ou faturamento, para permitir a avaliação relativa dos ativos; o segundo é a busca por empresas similares, o que é difícil em vista do fato de que não há duas empresas idênticas e de que as empresas de um mesmo setor podem apresentar diferenças quanto ao risco, potencial de crescimento e fluxos de caixa.

A grande maioria dos relatórios de análise patrimonial e muitas avaliações para fins de aquisição se baseiam em múltiplos como a razão preço/faturamento ou Valor/EBITDA ${ }^{2}$ e em um grupo de empresas comparáveis. A comparação é feita entre empresas do mesmo setor.

As vantagens do uso deste método é o fato de utilizar um número muito menor de parâmetros e premissas para se chegar ao valor da empresa. O tempo de processamento da informação é muito rápido, ou seja, com os valores a mão a ser comparados a avaliação é feita quase que instantaneamente. Outras vantagens; este método é mais simples de ser apresentado para os clientes do que uma avaliação por fluxo de caixa descontado (DCF), discutida anteriormente. Finalmente, as avaliações relativas têm uma probabilidade maior de refletir o estado atual do mercado por ser uma tentativa de medir o valor relativo e não intrínseco.

Estas vantagens são, ao mesmo tempo, suas desvantagens. Primeiro, a facilidade com que se pode complicar uma avaliação relativa, unindo um múltiplo a um grupo de empresas comparáveis, também pode resultar em estimativas inconsistentes de valor se forem ignoradas as variáveis fundamentais, como risco, crescimento ou potencial de fluxo de caixa. Segundo, como os múltiplos refletem o valor do mercado, isso implica que o valor de um ativo pode resultar em valores excessivamente elevados, se o mercado estiver superestimado. Outro desvantagem, é o fato da falta de transparência nas premissas fundamentais utilizadas na avaliação relativa as torna especialmente vulneráveis à manipulação.

Os múltiplos são valores padronizados que utilizam o valor de mercado de empresas de capital aberto, obtidos através do valor das ações negociadas em bolsa, para determinar o valor de empresas do mesmo setor. Os principais múltiplos segundo DAMODARAN (2002) são:

\footnotetext{
${ }^{2}$ Earnings before interest rate, depreciation and amortization.
} 
- Múltiplos de lucro: razão preço/lucro com base no lucro contábil divulgado pelas empresas, também denominado lucro por ação; pode se utilizar também o índice preço/lucro operacional antes da depreciação;

- Múltiplos de valor escritural ou de reposição: razão do preço/valor escritural das ações. A estimativa contábil de valor escritural da empresa utiliza como base regras contábeis e é influenciada pelos preços pagos originariamente pelos ativos e pela depreciação contábil;

- Múltiplos de Receitas: razão preço/vendas da empresa, muito menos afetada pelos princípios contábeis do que os múltiplos de valor escritural;

- Múltiplos setoriais específicos: os múltiplos anteriores podem ser utilizados para empresas de todo o mercado, mas há alguns que somente podem ser aplicados para empresas que atuem em um setor específico, como por exemplo, os múltiplos de empresas de Internet como a razão preço/acessos de Internet.

No setor de petróleo e gás, os múltiplos são muito utilizados para avaliar o valor do negócio e de investimentos necessários em novos projetos. Porém, este modelo se restringe por fatores geográficos como, por exemplo: empresas que exploram petróleo no Golfo do México e empresas instaladas na Arábia Saudita. Isto se deve ao fato da relação de custos de exploração, pois os custos de exploração em águas profundas são diferentes dos custos de exploração do continente. Além disso, existem diferentes tipos de petróleo do mais leve (Oriente Médio) que alcança preços mais elevados quando comparados ao óleo mais pesado (Venezuela). Mesmo assim, o mercado utiliza este método para comparar as empresas do setor.

No caso do álcool, biodiesel e carvão vegetal a utilização destas ferramentas, torna-se mais fácil, desde que sejam disponíveis alguns parâmetros padrões de comparação, como é caso da relação entre valor da empresa e capacidade de produção.

Os produtos gerados por este setor apresentam padronizações químicas como:

- Álcool: anidro - isento de água e hidratado - porcentagem de água admitida pela Petrobrás; 
- Biodiesel: relação padronizada de álcool anidro e óleos vegetais admitidos pela Petrobrás;

- Carvão vegetal: porcentagem de carbono fixo adaptado às condições operacionais do alto forno.

As usinas de álcool, biodiesel e carvão vegetal têm fontes de tecnologias comuns em que os fabricantes de máquinas, equipamentos e métodos de produção cobrem todos os produtores. Desta forma, as usinas modernas estão nos mesmos patamares de custos de produção.

Com relação ao preço praticado todas elas são balizadas no caso do álcool e biodiesel a Petrobrás e no caso do carvão vegetal as grandes siderúrgicas.

O acesso a fonte de insumos para estas usinas estão distribuídas geograficamente:

- Álcool: empresas instaladas em São Paulo;

- Carvão Vegetal: empresas instaladas em Minas Gerais;

- Biodiesel: empresas instaladas no Nordeste brasileiro e Centro Oeste.

De posse destas informações, criar uma relação de capacidade de produção versus valor da empresa, tona-se um dos objetivos do trabalho proposto.

\subsubsection{Opç̃̃es Reais como método de avaliação}

A abordagem de opções reais é utilizada para avaliação de empresas utilizando opções. Esta técnica, descrita neste tópico, é um complemento ao método de fluxo de caixa descontado $(D C F)$.

É uma extensão da teoria de opções financeiras, aplicadas à avaliação de ativos reais, ou "não financeiros". AMRAN \& KULATULAKA (1999) sugerem que a mudança das opções financeiras para as opções reais requer uma nova forma de pensar, uma forma que faça a ligação entre a disciplina dos mercados financeiros e das decisões de investimentos estratégicos. 
Segundo CASTRO (2000), “A teoria das opções reais é uma metodologia para avaliação de ativos reais como, por exemplo, projetos de investimentos, que leva em conta a flexibilidades operacionais e gerenciais ao longo da vida útil do projeto. Sua característica dinâmica, diferente de técnicas tradicionais como Valor Presente Líquido (VPL), conduzem a resultados mais realistas. A flexibilidade que um gerente tem para tomar decisões sobre ativos reais. À medida que novas informações surgem e as incertezas sobre o fluxo de caixa revelam-se, o gerente pode tomar decisões que influenciarão positivamente o valor final do projeto. As decisões mais comuns são: saber o momento certo de investir ou abandonar um projeto, modificar as características operacionais de um ativo ou trocar um ativo por outro. Assim, um investimento de capital pode ser considerado um conjunto de opressões reais sobre um ativo real".

MYERS (1977) afirma que as oportunidades de expansão de uma empresa podem ser vista como sendo análogas às opções de compra, negociadas no mercado financeiro.

Uma opção real, segundo COPELAND e ANTIKAROV (2001), é "o direito, mas não a obrigação, de empreender uma opção (por exemplo, diferir, expandir, contrair ou abandonar) a um custo predeterminado, que se denomina preço de exercício, por um período préestabelecido - a vida da opção". Ainda classifica as opções em cinco categorias. São identificados os seguintes tipos de opções:

a) Opção de abandonar: a opção de abandonar ou vender um projeto é similar à opção americana de venda. Na realização de resultados abaixo do esperado pelo investidor, este pode optar em vender o projeto. Assim sendo, o valor esperado de liquidação correspondem ao valor de exercício da opção. Fica evidente que um projeto que ser liquidado é, portanto, mais valioso que o mesmo projeto sem a possibilidade de abandono.

b) Opção de adiar o desenvolvimento: esta modalidade de adiar um investimento é similar a uma opção americana de compra. O custo de desenvolvimento esperado é o preço de exercício da opção. O seu resultado líquido operacional menos a depreciação do ativo é o custo de oportunidade. Caso este resultado seja muito satisfatório, o investidor pode decidir exercer a opção de desenvolver o projeto antes do previsto. Analogamente, um projeto que pode ser adiado vale mais do que um projeto sem tal flexibilidade. 
c) Opção de expandir: a opção de expandir a escala de operação de um projeto é formalmente equivalente a uma opção de compra americana. Como a opção de expandir concede à gestão o direito, mas não a obrigação, de fazer investimentos adicionais subseqüentes se as condições do projeto passarem a ser favoráveis, um projeto que pode ser expandido, vale mais do que o mesmo projeto sem a flexibilidade de expansão.

d) Opção de contratar: a opção de contratar um projeto é equivalente a opção americana de venda. Muitos projetos podem ser planejados de forma a possibilitar a contratação futura de produção. Estes gastos futuros planejados são equivalentes ao preço de exercício da opção de venda. Como a opção de contratar concede o direito de reduzir a escala de operação se as condições passarem as ser desfavoráveis, um projeto que pode ser contratado vale mais que um projeto sem a flexibilidade de contratar.

e) Opção de alternância: a opção de alternar operações de um projeto corresponde a uma carteira de opções de compra e de venda. O custo de reiniciar (ou de encerrar) operações pode ser visto como o preço de exercício da opção. Um projeto que pode ser interrompido e reiniciado vale mais do que um projeto sem esse tipo de flexibilidade.

Este método é uma alternativa de utilização de teoria de opções para avaliar a flexibilidade de tomadas de decisões no futuro. Consiste em um modelo que avalia uma empresa no qual o investidor possui a flexibilidade de expandi-la no futuro, caso o negócio esteja indo bem; ou a possibilidade de retrair as atividades, caso esteja indo mal. Esta possibilidade de tornar o negócio flexível vale mais do que uma outra empresa no qual não exista essa flexibilidade. A possibilidade de se tomar decisões de investimento no futuro aumenta o valor do negócio, pois diminuem o risco de perdas e aumentam a possibilidade de ganhos futuros.

Segundo COPELAND e ANTIKAROV (2001), a opção real depende de cinco variáveis, sendo elas:

- Ativo subjacente: projeto ou investimento de capital;

- Preço de exercício: custo fixado de investimento futuro em um determinado projeto para expandi-lo ou atrasá-lo. Pode ser também, no caso de opção de venda, o montante que se obtém com o abandono ou retração de um projeto no futuro; 
- Prazo de vencimento: prazo no qual se pode tomar decisão. Expirando esse prazo, o investidor perde a flexibilidade;

- Desvio padrão dos retornos do ativo subjacente: variável na qual o valor da opção depende, quanto maior o desvio-padrão, maior o valor da opção;

- Taxa de juros livre de risco: é custo de oportunidade do investimento.

\subsubsection{Riscos na avaliação de empresas no Brasil}

A avaliação de uma empresa com base em projeções de fluxos de caixa, como é feito no método DCF, pode carregar intrinsecamente um nível considerável de incertezas das projeções. Esta constatação é agravada quando se trata de avaliações de empresas que operam em mercados com falta de maturidade como é o caso do Brasil.

O tratamento estatístico adequado a este tipo de risco é o de não buscar um valor teórico no valor da empresa, mais sim valores que estejam dentro de um grau de confiança. Porém, quanto maior as incertezas utilizadas no cálculo, maior será o número de diferentes valores a serem considerados como o valor da empresa.

Uma das formas para tratar incertezas nas projeções de fluxo de caixa é utilizando o método da Teoria das Opções Reais, porém, conforme observado, tal método carrega dificuldades inerentes a sua modelagem, dentre elas a dificuldade em encontrar informações no mercado financeiro que sirvam de parâmetros para tal modelagem.

A opção mais correta é tratar este tipo de risco na avaliação, considerando o fluxo de caixa projetado como variável aleatória, conforme modelado por SECURATO (1996). Ao fazer esta consideração, criamos para cada período não apenas uma projeção discreta de caixa, mas sim uma distribuição de possíveis valores de caixa contidos em um intervalo.

PARK (1990) define que:

"uma vez que um processo aleatório controla os valores adotados para cada fluxo de caixa $\left(C F_{t}\right)$, as freqüências relativas dos valores aleatórios adotados para o fluxo de caixa podem usualmente ser representados por funções probabilidade ou densidade $f$ $\left(C F_{t}\right)$. Essa aleatoriedade pode ser expressa pela média e variância da distribuição de 
$F C_{t}$. Assim, o somatório dos fluxos de caixa aleatórios descontados para obter o valor presente líquido do projeto é também uma variável aleatória"

Da modelagem desenvolvida por PARK(1990) obtém-se uma média da variável aleatória PV igual a :

$$
E[P V]=\sum_{t=0}^{N} \frac{E\left(F C_{t}\right)}{(1+i)^{t}} \quad \text { Equação } 8
$$

O valor da variância do valor presente dependerá da relação entre os fluxos de caixa projetado. Na definição do autor, "diz-se que diversos fluxos de caixa são completamente independentes se não houver relação causativa ou conseqüencial entre quaisquer fluxos de caixa tomados dois a dois. Caso contrário, os fluxos de caixa serão dependentes, e o grau de dependência entre os fluxos de caixa será determinado por um coeficiente de correlação".

Na hipótese formulada acima de haver alguma correlação, o cálculo da variância de um fluxo de caixa liquido é expresso pela seguinte equação:

$$
\operatorname{Var}[P V]=\sqrt{\sum_{t=0}^{N} \frac{\sigma_{t}^{2}}{(1+i)^{2 t}}+2 \sum_{t=0}^{N-1} \sum_{s=t+1}^{N} \frac{\rho_{t s} \sigma_{t} \sigma_{s}}{(1+i)^{t+s}}}
$$

Onde $\sigma_{t}$ é o desvio padrão do fluxo de caixa no ano $t$ e $\rho_{t s}$ é o coeficiente de correlação entre os fluxos de caixa nos momentos $t$ e $s$. Da equação acima, obtém-se a equação que determina o desvio padrão para o valor presente líquido dos fluxos de caixa:

$$
S[P V]=\sqrt{\sum_{t=0}^{N} \frac{\sigma_{t}^{2}}{(1+i)^{2 t}}+2 \sum_{t=0}^{N-1} \sum_{s=t+1}^{N} \frac{\rho_{t s} \sigma_{t} \sigma_{s}}{(1+i)^{t+s}}}
$$

Para a hipótese de independência do fluxo de caixa, ou seja, não havendo correlação entre eles, a equação 9 e equação 10 podem ser simplificadas com a anulação de suas componentes de covariância. Resultariam as seguintes equações:

$$
\begin{aligned}
& \operatorname{Var}[P V]=\sqrt{\sum_{t=0}^{N} \frac{\sigma_{t}^{2}}{(1+i)^{2 t}}} \\
& S[P V]=\sqrt{\sum_{t=0}^{N} \frac{\sigma_{t}^{2}}{(1+i)^{2 t}}}
\end{aligned}
$$


É possível desenvolver através da Simulação de Monte Carlo um conjunto de possíveis resultados de caixa gerados aleatoriamente a partir das variáveis incertas, criando assim um modelo adequado para a análise aleatória de valor. Para cada variável aleatória, definem-se possíveis valores com uma distribuição de probabilidade, sendo aleatória podemos trabalhar com uma distribuição normal.

Para o valor da empresa um cenário de possíveis situações na empresa no setor de biomassa com seus respectivos níveis de volatilidade dos indicadores e a correlação entre eles os riscos envolvidos com o setor: preço do petróleo, questões sociais, ambientais, barreiras setoriais e entrada de novos concorrentes. 


\section{O SETOR DE BIOCOMBUSTÍvEIS NO BRASIL E NO MUNDO}

O desenvolvimento limpo encerra a idéia instintiva de servir para arquitetar projetos de sistemas energéticos eficientes e de custo competitivo que considerem na sua construção o exaurimento dos recursos, o meio ambiente e o desenvolvimento sustentável. A consciência de um mundo com recursos finitos de demanda de energia em crescimento obriga a incorporar, no desenvolvimento humano, o entendimento dos mecanismos que degradam a energia e os recursos e o emprego de metodologias sistêmicas para a melhoria de sistemas de energia e a redução de danos ao ambiente.

\subsection{Definições do setor de biomassa como fonte de energia}

O conceito de produtos da biomassa deve garantir:

- Renovabilidade: característica associada à possibilidade física de reposição, mediante processos naturais e em escalas de tempo humanas, das reservas associadas a uma determinada fonte energética. Renovabilidade - pressuposto da sustentabilidade necessário, mas não suficiente.

- Sustentabilidade: possibilidade dos sistemas energéticos se manterem saudáveis, estáveis e produtivos sem depreciar suas reservas naturais, dentro de um marco de viabilidade econômica e aceitabilidade social. Bioenergias: casos mais complexos na determinação da sustentabilidade.

A biomassa tem diversas aplicações, mas as que mais se destacam são as indústrias de papel/celulose, óleos, energia e biocombustíveis. O projeto foca no uso da biomassa para fins energéticos e os principais produtos de estudo são apresentados abaixo. 


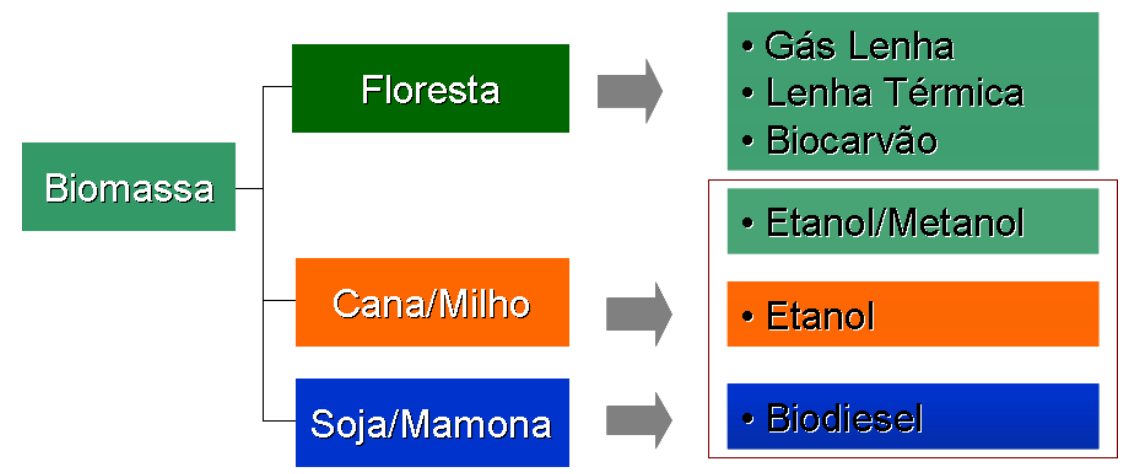

Figura 3: Árvore de produtos da biomassa.

- Biocombustíveis

\subsection{Matriz energética}

A crise do petróleo na década de 70, escassez de carvão mineral e investimentos em outras fontes de energia colocaram o Brasil na liderança em fontes renováveis. Para os próximos anos, o uso de biodiesel, aumento no consumo de etanol e carvão vegetal reflorestado provocará mudanças ainda maiores na matriz energética brasileira. O gráfico 3.1 apresentam a oferta de energia mundial e brasileira.

\section{Oferta Mundial de Energia \\ Primária, 2002}

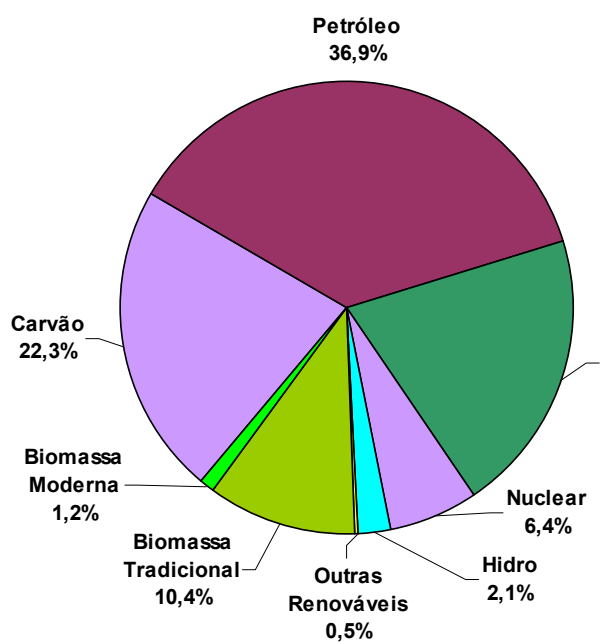

Oferta de Energia Primária no Brasil, 2002

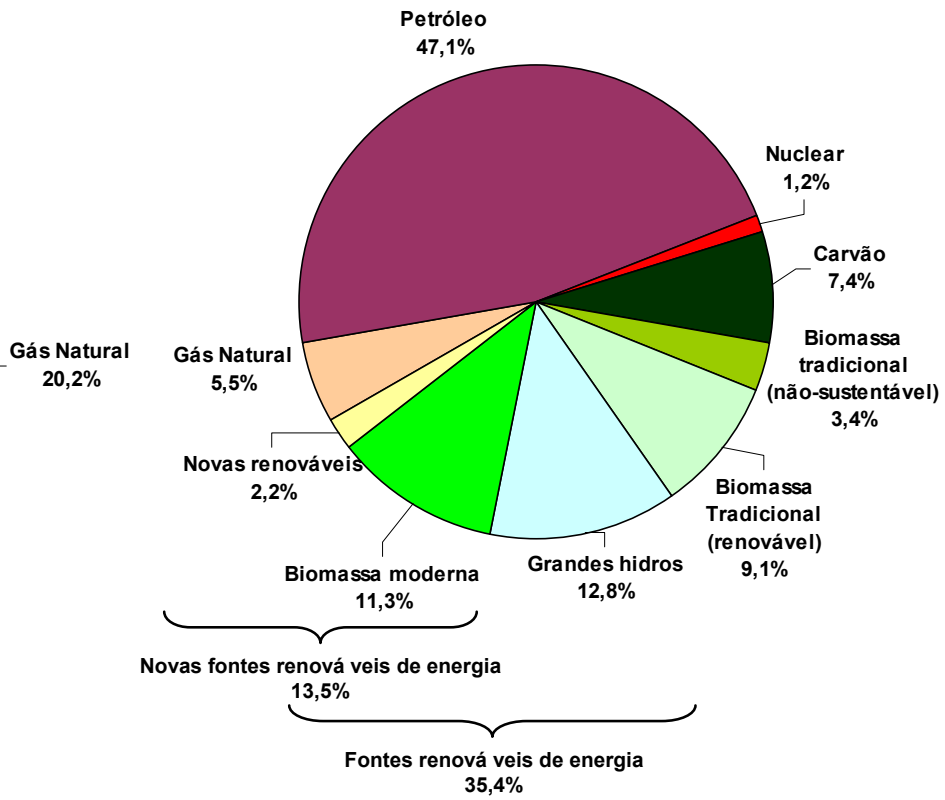

Gráfico 2: Oferta Mundial de Energia Primária, 2002/Oferta de Energia no Brasil, 2002.

Fonte: IEA (International Energy Agency) e Balanço Energético Nacional (Ministério das Minas e Energia). 
As políticas para encorajar o desenvolvimento sustentável têm de ser implementadas ao mesmo tempo e de forma efetiva para que os objetivos sejam alcançados. Elas apontam para a eficiência dos mercados como forma de alcançar o desenvolvimento sustentável. Alguns itens estão inclusos nesse amplo conceito de fazer os mercados funcionarem melhores:

- Reestruturar o setor energético;

- Atrair capital externo;

- Diminuir subsídio para suprimentos de energia de fontes convencionais;

- Internalizar aspectos externos, como impactos à saúde e ao ambiente;

- Promover a eficiência energética;

- Apoiar a inovação no setor de energia e acelerar o uso de fontes renováveis;

- Criar capacidade institucional e humana no campo da energia sustentável;

- Introduzir medidas regulatórias mais efetivas, para melhorar as operações de mercado e atingir os benefícios públicos, e

- Atingir uma cooperação internacional mais efetiva, assim como aumentar elos entre mercados multilaterais e medidas ambientais.

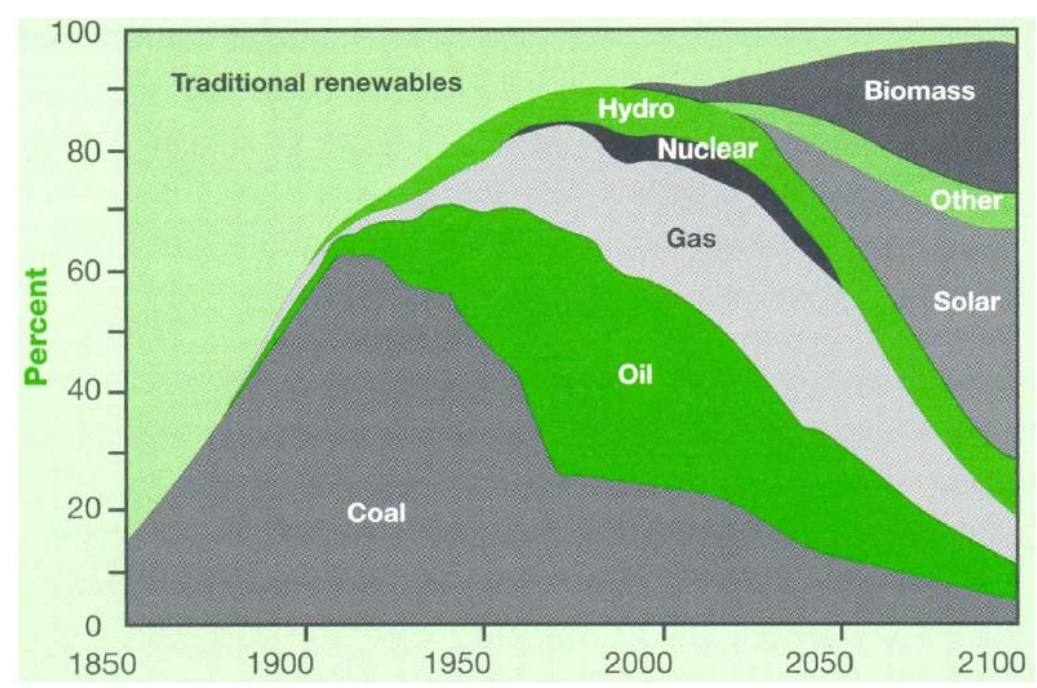

Gráfico 3: Evolução da Demanda Mundial de energia entre 1850-2100. Fonte: UNDP; UNDESA; WEC (2000). 
O gráfico acima aponta como possível cenário o crescimento do uso da bioenergia, na medida em que novas tecnologias forem aperfeiçoando o custo para produção da bioenergia vão se tornando atrativos.

\subsection{A globalização no setor}

Já se tornou uma banalidade dizer que estamos vivendo um momento de aceleração na História. Mas é menos trivial e mais complexo decifrar o sentido desta aceleração, identificar as transformações que está provocando, as demandas novas e prementes que está gerando para os países, organizações, empresas e mesmo indivíduos. Desafio maior é tirar as conseqüências dessas transformações para as políticas de crescimento, particularmente a política de exportação.

A capacidade de entender o processo global e seu rumo, antecipar decisões e políticas, dar uma resposta adequada às novas realidades é, em boa medida, o que distingue o êxito do fracasso, a capacidade de liderar ou ser objetos dessas transformações. Os países que lograram colocar os seus barcos na direção da correnteza tiveram mais chances para recolher as vantagens da globalização; outros que pareceram querer navegar contra a maré, enfrentaram dificuldades, quando não ficam à margem do rio. No primeiro caso estão, por exemplo, a China, a Índia, e bom número de nações asiáticas. No segundo, alguns países da América Latina e África.

Walker (2006) comenta a queda da participação dos países que integram América Latina que em 1950 representava $12 \%$ do comércio internacional, hoje caiu para 3\%. O autor cita a oportunidade da globalização para retomarmos o caminho perdido nos anos 80 e 90, épocas conhecidas do crescimento vertical dos países asiáticos.

Considerando o pensamento dos dois atores, se faz necessários que o Brasil assuma a sua posição como potencia mundial ao lado da China, Índia e Rússia (BRICS). Para tanto, existe a necessidade de reconhecer a suas diferenças e potencialidades. De suas vantagens como setores da economia destacam-se os setores de agronegócios, siderurgia, mineração, papel e celulose. Porém, ressalto um setor que irá representar uma vantagem competitiva por diversas razões que é o setor de bioenergia, especialmente a biomassa. 
MEIRELLES, J. CARLOS ${ }^{3}$ (2005) destaca o papel da competitividade para o sucesso no comércio exterior, destacando como importantes elementos: recursos humanos, infra-estrutura e inovação tecnológica.

MURAT, L. GONZAGA ${ }^{4}$ (2005) apresenta alguns pilares para o desenvolvimento setorial no Brasil: vantagens competitivas do processo, vantagens comparativas e oportunidade de mercado. Estes 3 pontos apontam para o setor de bionenergia, pois os três aspectos são evidentes neste setor.

- Competitivas: baixo custo de produção e desenvolvimento tecnológico;

- Comparativas: o país apresenta grande quantidade de terras, altos níveis de insolação e fonte de água.

- Oportunidade de mercado: demanda por combustíveis alternativos, ou seja, energia que substitua o carvão e o petróleo.

\subsection{Importâncias na redução das emissões de gases}

A inserção do Brasil no mercado internacional teve destaque no mercado de carbono. Criado pela Convenção de Quadra da ONU sobre mudança de clima. Representa um compromisso aceito pelos países desenvolvidos, neste caso os mais poluidores, chamado de Anexo 1. Esses países se comprometeram a reduzir as emissões de gases de efeito estufa em 5\%, entre 2008 e 2012, com base em 90. Com este cenário, surgiu o Protocolo de Kyoto, oportunidade interessante para países como o Brasil - não integrante do Anexo 1. Esse protocolo permite que países incapacitados de reduzir suas emissões invistam em projetos de captação de $\mathrm{CO}_{2}$ em países não-Anexo 1. E, ao fazer isso, os países pertencentes ao Anexo 1, recebem os certificados de emissão conhecidos como CRs. Portanto, surge uma oportunidade para que o Brasil receba capital estrangeiro para financiar projetos no setor de bioenergia.

As etapas sobre conferencias do clima:

- 1979 - Primeira Conferência Mundial do Clima.

\footnotetext{
${ }^{3,5}$ Artigo pertencente ao livro: SAVOIA, JOSE ROBERTO FERRERIA. A inserção do Brasil na Comunidade Internacional: Desafios e Oportunidades.
} 
- 1990 - Segunda Conferência do Clima.

- Primeiro Relatório do IPCC com fortes evidências de que atividades humanas estão alterando o clima.

- 1992 - Rio de Janeiro - United Nations Framework Convention on Climate Change (UNFCCC).

- Países do Anexo I se comprometem a reduzirem suas emissões aos níveis de 1990 até o ano de 2000;

- E.U.A. ratifica a UNFCCC.

- 1995 - COP 1 - Mandato de Berlin.

Estabelece metas e cronogramas específicos para cada país do Anexo I.

- 1997 - COP 3 - Quioto - Protocolo de Quioto.

- Países do Anexo I concordam em reduzir as emissões em 5\% abaixo dos níveis de 1990 até 200 - 2010, utilizando "Mecanismos de Flexibilidade", incluindo o comércio de emissões;

- Senado dos E.U.A. aprova, por 95 a 0, a Resolução Burd-Hagel.

- 1992 - COP 4 - Buenos Aires - Dá ênfase no desenvolvimento do M.D.L.

- 2002 - União Européia ratifica o Protocolo de Quioto.

- 2003 - Reflorestamentos são incluídos oficialmente COP 9 - Milão.

\subsection{Panorama do setor}

PACHECO, AMARAL ${ }^{5}$ (2005) apresenta os setores biomassa, energia limpa e setores associados terem grande potencial de crescimento futuro. Comenta que não são setores com

\footnotetext{
${ }^{5}$ Artigo pertencente ao livro: SAVOIA, JOSE ROBERTO FERRERIA. A inserção do Brasil na Comunidade Internacional: Desafios e Oportunidades.
} 
atividades exclusivamente baseada em recursos naturais, porque a base de competência instalada para gerenciar esse tipo de indústria, na frente, é extremamente importante. Além disso, varias dessas indústrias novas se acoplam a outros segmentos. Por exemplo, constituir um mercado de energia renovável no mundo, à base de etanol, implica não só em ser competente em biotecnologia aplicada ao agronegócio, mas também ter um enorme complexo metal mecânico capaz de produzir usina a baixo custo, com tecnologia, e vendê-la no mundo inteiro. $\mathrm{O}$ etanol só vai ser uma commodity internacional quando existirem vários produtores no mundo. Além de álcool, podemos ser vendedores de tecnologia de usinas.

\subsubsection{Biodiesel}

O biodiesel é um combustível que pode ser fabricado a partir de uma série de matérias-primas (óleos vegetais diversos, gordura animal, óleo de fritura) através dos processos de transesterificação e craqueamento. O processo que tem apresentado resultados técnicoeconômicos mais satisfatórios é a transesterificação, no qual ocorre uma reação entre o óleo vegetal e um álcool (metílico ou etílico), na presença de um catalisador, e cujos produtos são um éster de ácido graxo (biodiesel) e glicerina.

A utilização do biodiesel é bastante difundida, principalmente na Europa Ocidental, cuja produção anual em 2003 atingiu 2,5-2,7 milhões de toneladas, a Alemanha é o maior produtor mundial, respondendo por $42 \%$ da produção de 2002 (FULTON et al, 2004). Nestes países o biodiesel é produzido a partir da reação de transesterificação entre o óleo de canola e o metanol (derivado do gás natural ou petróleo) (NOGUEIRA; MACEDO, 2005).

No caso brasileiro são utilizados óleos vegetais de diversas oleaginosas, conforme as espécies produzidas em cada região, por exemplo, óleo de palma na região Norte, óleo de mamona na região Nordeste, óleo de soja na região Centro-Oeste. O álcool utilizado na reação será o etanol, produzido a partir da cana-de-açúcar. O biodiesel produzido será um combustível totalmente renovável.

Em 02 de julho de 2003, a Presidência da República instituiu por meio de Decreto um Grupo de Trabalho Interministerial encarregado de apresentar estudos sobre a viabilidade da utilização energética do biodiesel. A partir do relatório elaborado por este Grupo o Governo Federal estabeleceu o Plano Nacional de Produção e Uso do Biodiesel (PNPB), cujos objetivos são a implantação sustentável do programa do biodiesel, promovendo a inclusão 
social, garantia de preços competitivos, suprimento e qualidade e produção de biodiesel a partir de diferentes oleaginosas em todo o território nacional.

Em 13 de janeiro de 2005 foi publicada a Lei 11.097, que dispõe sobre a introdução do biodiesel na matriz energética brasileira, estabelece a obrigatoriedade da adição de um percentual mínimo de biodiesel ao óleo diesel vendido ao consumidor final, em qualquer parte do território nacional. Esse percentual obrigatório será de 5\% a partir de janeiro de 2013 (oito anos após a publicação desta Lei), havendo um percentual obrigatório intermediário de $2 \%$ três anos após a publicação da mesma (início de 2008).

O Decreto $n^{\circ} .5 .298$, de 6 de dezembro de 2004, autoriza, a partir da data de sua publicação, a adição de até $2 \%$ de biodiesel ao diesel vendido no Brasil. A mistura já pode ser encontrada em alguns postos de combustível nos Estados de São Paulo, Rio de Janeiro, Minas Gerais, Goiás e no Distrito Federal.

Como forma de garantir a participação de pequenos produtores rurais, e assim promover a inclusão social, o Governo Federal criou uma série de incentivos aos produtores de biodiesel:

- Selo Combustível Social: concedido pelo Ministério do Desenvolvimento Agrário MDA ao produtor de biodiesel que cumpre os critérios descritos na Instrução Normativa I e que confere ao seu possuidor o caráter de promotor de inclusão social dos agricultores familiares enquadrados no Programa Nacional de Fortalecimento da Agricultura Familiar (PRONAF), conforme estabelecido no Decreto $n^{\circ} 5.297$, de 06 de dezembro de 2004. O enquadramento social de projetos ou empresas produtoras de biodiesel permite acesso a melhores condições de financiamento junto ao BNDES e outras instituições financeiras, além dar direito de concorrência em leilões de compra de biodiesel.

- Desoneração tributária: a alíquota máxima de PIS/PASEP e COFINS incidentes sobre a receita bruta obtida pelo produtor ou importador, na venda de biodiesel, fica reduzida para $\mathrm{R} \$ 217,96$ por $\mathrm{m} 3$, equivalente a carga tributária federal para o diesel de petróleo. Entretanto foram estabelecidos três níveis de desoneração tributária para redução da alíquota máxima, de acordo com os critérios dispostos na Lei no ${ }^{\circ}$ 11.116, de 18 de maio de 2005. 
- biodiesel fabricado a partir de mamona ou a palma produzida nas regiões Norte, Nordeste e no Semi-Árido pela agricultura familiar: a desoneração de PIS/PASEP e COFINS é total, ou seja, a alíquota efetiva é nula;

- biodiesel fabricado a partir de qualquer matéria-prima que seja produzida pela agricultura familiar, independentemente da região: a alíquota efetiva é R\$ 70,02 / m3 (67,9\% de redução em relação à alíquota geral);

- biodiesel fabricado a partir de mamona ou a palma produzida nas regiões Norte, Nordeste e no Semi-Árido pelo agro-negócio: a alíquota efetiva é R\$ 151,50 / m3 (30,5\% de redução em relação à alíquota geral).

Foram criados programas no Brasil para desenvolvimento da cadeia produtiva do biodiesel de forma sistêmica: a) Na produção agrícola, com linhas de crédito de custeio, investimento e comercialização, disponíveis para financiamento ao produtor rural familiar e empresarial. b) $\mathrm{Na}$ industrialização: BNDES Biodiesel, Pronaf Agroindústria, Prodecoop, Crédito Agroindustrial (aquisição de matéria-prima), além das linhas disponíveis para o setor industrial.

O principal critério a ser considerado pelo Banco na concessão do crédito, além das exigências específicas de cada linha, é a garantia de comercialização tanto da produção agrícola quanto do biodiesel. Inicialmente serão priorizadas as culturas de dendê, mamona, soja, algodão, girassol e nabo forrageiro, observando-se o zoneamento agrícola e a aptidão regional. No dia 23 de novembro de 2005, a ANP (Agência Nacional do Petróleo, Gás Natural e Biocombustíveis) realizou o primeiro leilão para compra e venda de biodiesel, no qual foram comercializados 70 milhões de litros deste combustível. Foram autorizadas a participar do leilão empresas que possuem o "Selo Combustível Social", autorização da ANP para produção de biodiesel e em situação regular junto à Receita Federal. A realização deste leilão teve como principal objetivo garantir um mercado aos produtores de combustível e agricultores rurais. Segundo estimativa da Agência, até dezembro de 2007 deve ser adquirida 800 milhões de litros de combustível.

O setor ainda encontra-se em franca expansão, para atender a crescente demanda proposta pelo governo, surge a necessidade de uma política com incentivos. Na tabela abaixo estão listadas os números de empresas que estão autorizadas para a fabricação de biodiesel no Brasil. 


\begin{tabular}{|c|c|c|c|}
\hline Empresa & Local & $\begin{array}{c}\text { Capacidade } \\
\text { Autorizada } \\
\left(\mathrm{m}^{3} / \mathrm{dia}\right)\end{array}$ & $\begin{array}{c}\text { * Capacidade } \\
\text { Anual } \\
\text { Estimada } \\
\left(10^{3} \mathrm{~m}^{3} / \mathrm{ano}\right)\end{array}$ \\
\hline Agropalma & Bélem/PA & 80,0 & 24,0 \\
\hline Agrosoja & Sorriso / MT & 80,0 & 24,0 \\
\hline Bsbios & Passo Fundo / RS & 345,0 & 103,5 \\
\hline Barralcóol & Barra do Bugres/MT & 166,7 & 50,0 \\
\hline BioCamp & Campo Verde / MT & 154,0 & 46,2 \\
\hline Biopar & Rolândia / PR & 120,0 & 36,0 \\
\hline Biocapital & Charqueada/SP & 186,0 & 55,8 \\
\hline Binatural & Formosa/GO & 30,0 & 9,0 \\
\hline Biolix & Rolândia/PR & 30,0 & 9,0 \\
\hline Biopetrosul & Taubaté/SP & 21,3 & 6,4 \\
\hline Brasil Ecodiesel & Floriano/PI & 135,0 & 40,5 \\
\hline Brasil Ecodiesel & Crateús/CE & 360,0 & 108,0 \\
\hline Brasil Ecodiesel & Porto Nacional / TO & 360,0 & 108,0 \\
\hline Brasil Ecodiesel & São Luis / MA & 360,0 & 108,0 \\
\hline Brasil Ecodiesel & Iraquara/BA & 360,0 & 108,0 \\
\hline Brasil Ecodiesel & Rosário do Sul / RS & 360,0 & 108,0 \\
\hline Caramuru & São Simão / GO & 375,0 & 112,5 \\
\hline Dhaymers & Taboão da Serra/SP & 26,0 & 7,8 \\
\hline Fertibom & Catanduva/SP & 40,0 & 12,0 \\
\hline Fusermann & Barbacena/MG & 30,0 & 9,0 \\
\hline Granol & Anápolis/GO & 333,3 & 100,0 \\
\hline Granol & Campinas/SP & 133,0 & 39,9 \\
\hline IBR & Simões Filho/BA & 65,0 & 19,5 \\
\hline KGB & Sinop/MT & 5,0 & 1,5 \\
\hline NUTEC & Fortaleza/CE & 2,4 & 0,7 \\
\hline Oleoplan & Veranópolis / RS & 327,0 & 98,1 \\
\hline Ouro Verde & Rolim de Moura/RO & 17,0 & 5,1 \\
\hline PonTe di Ferro & Taubaté/SP & 90,0 & 27,0 \\
\hline PonTe di Ferro & Manguinhos/RJ & 160,0 & 48,0 \\
\hline Renobras & DomAquino/MT & 20,0 & 6,0 \\
\hline Soyminas & Cássia/MG & 40,0 & 12,0 \\
\hline Usibio & Sinop / MT & 20,0 & 6,0 \\
\hline & Total & $4.831,7$ & $1.449,5$ \\
\hline
\end{tabular}

Tabela 2 - Empresas autorizadas a operar com o biodiesel no Brasil Fonte: ANP; obs: ultima atualização em junho/2007; * 300 dias de operação.

Muitas oleaginosas podem ser usadas para a produção de biodiesel. A área para suprir 5\% do diesel B5 com oleaginosas locais, e usando apenas soja, dendê e mamona, seria cerca de 3 milhões de hectares. A área de expansão possível para grãos é de pelo menos 90 milhões de hectares. As áreas aptas para o dendê atingem, na Amazônia, cerca de 70 milhões de hectares, com alta aptidão em cerca de $40 \%$.

Se considerarmos o valor do produto, a mamona pode ser uma opção agrícola rentável para as regiões árida e semi-árida do Nordeste, independente do uso para biodiesel. 
Segundo dados de 2002, a cultura da mamona no país é pequena, de 130 mil hectares. Constitui-se principalmente de pequenas unidades, de aproximadamente 15 hectares. Se considerarmos um programa de substituição a $1 \%$ do óleo diesel a partir da mamona, seria preciso multiplicar por oito a produção atual. Neste caso, seria essencial o fortalecimento da base agrícola com maior número de variedades. Teoricamente isto é possível, mas neste nível tratar-se- ia de programa muito mais voltado a atender aspectos sociais do que às necessidades de energia. O modelo proposto para a produção, de agricultura familiar "assistido" em assentamentos, deve ser bem avaliado nos seus múltiplos aspectos, com ênfase em custos totais e renda. Deve-se considerar a alternativa de exportação do óleo de mamona para usos não energéticos.

A soja conta com uma base agrícola variada e tecnologia adequada, além de uma enorme experiência da produção como cultura extensiva, de grandes áreas. Utiliza 20 milhões de hectares e dispõe de 100 milhões de hectares aptos para expansão. Não há limitações nem técnicas, nem de áreas para suportar um programa de biodiesel para misturas.

O dendê, independente de programas para biodiesel, deve merecer muita atenção. A produção mundial de óleo de dendê deverá ultrapassar a de soja no final da década. O Brasil produz apenas $0,5 \%$ do total mundial, embora tenha o maior potencial do mundo em áreas com aptidão agrícola. Existe uma experiência em curso, de agricultura familiar "assistida", que deve ser bem avaliada. A atual oferta de variedades é adequada somente para a pequena produção. A expansão do plantio para a produção de óleo de dendê exigirá o fortalecimento da pesquisa agronômica.

O uso do biodiesel reduz as principais emissões locais associadas ao diesel, de PM, CO, HC e SOx, exceto dos NOx (+2 a 4\%, com B20). É não-tóxico e biodegradável. São características muito importantes para centros urbanos no Brasil.

Com relação às emissões de GEE, resultados para biodiesel puro (B100) indicam reduções de 40 a $60 \%$ das emissões correspondentes ao diesel com colza da Europa. Dependem muito da matéria-prima e do tratamento dado aos subprodutos.

Os balanços energéticos indicam que as reduções no Brasil, com soja, não seriam maiores. São relevantes, mas o valor associado a possíveis créditos de carbono é pequeno. Para o crédito entre US\$ 1 e $5 / \mathrm{t}$ de carbono evitado, corresponderiam cerca de $3 \%$ do custo de produção. 
O agronegócio da soja gera empregos diretos para 4,7 milhões de pessoas em diversos segmentos, de insumos, produção, transporte, processamento e distribuição, e nas cadeias produtivas de suínos e aves. A produção correspondente é de $52 \mathrm{M} \mathrm{t,} \mathrm{em} 20 \mathrm{M}$ ha.

Um exemplo para o dendê (com 33 mil hectares plantados e 25 mil em produção), considerando somente os empregos diretos na produção agrícola, indica a geração de 3 mil empregos diretos, o correspondente, em agricultura familiar "assistida", a uma família para 10 ha. Considerando-se somente os empregos diretos na produção de matéria-prima, prevê-se que os assentamentos para o plantio de mamona gerem um emprego para cada 10-15 ha.

A plena implementação do B5 poderá gerar aproximadamente 260 mil empregos diretos na fase agrícola. A esta demanda de mão-de-obra devem ser agregadas as necessidades da fase industrial e de logística do biodiesel. Para chegar a esta previsão, a Embrapa adotou uma média de 0,09 empregos por ha, valor aproximado entre os observados para a agricultura familiar e a agroindústria considerando as projeções de área a ser cultivada.

\section{Biodiesel no mundo}

Para contextualizar alguns dos pontos que consideramos essenciais, resumimos algumas análises muito recentes, de 2004, sobre o maior programa de biodiesel do mundo, que ocorre na União Européia, e apresentamos dados concisos sobre programas selecionados em outros países.

No final de 2003, a capacidade instalada na Europa ocidental e oriental era de cerca de 2,5 2,7 M t, com expectativas de atingir 3,3 M t no final de 2004. O direcionamento do programa de biodiesel da União Européial objetiva a substituição de $2 \%$ do diesel usado para transportes em 2005; 5,75\% em 2010, e 20\% em 2020.

A maior parte do óleo vegetal empregado neste programa vem do cultivo da colza. No momento, os custos de produção de óleo vegetal são, em média, cerca de duas vezes superiores ao do diesel mineral. Para atingir a meta de 2010 nas condições atuais, o nível de subsídios em forma de isenção de impostos seria de aproximadamente 2,5 bilhões/ ano.

O programa americano de biodiesel é bem menor que o europeu e apresenta diferenças importantes. A principal matéria-prima utilizada é a soja, complementada com óleos de fritura usados. 
De acordo com o National Biodiesel Board, em 2002, foram produzidos aproximadamente 50 milhões de litros de biodiesel, usados basicamente como B20, mistura com 20\% de biodiesel. Atualmente existem mais de 12 companhias produzindo este combustível nos Estados Unidos, com uma capacidade de produção da ordem de 200 mil toneladas anuais.

\subsubsection{Etanol}

Desde sua efetiva incorporação à matriz energética brasileira, em 1975, até a atualidade, o etanol conseguiu importantes resultados:

- A produção e a demanda ultrapassaram largamente as expectativas colocadas no início do Programa Nacional do Álcool.

- A implementação de tecnologias e avanços gerenciais tornaram este combustível renovável competitivo com os combustíveis fósseis.

- As características de sua produção o tornam a melhor opção, no momento, para a redução de emissões de gases de efeito estufa no setor de transportes, em todo o mundo. Este estudo avalia quais seriam as vantagens e as dificuldades a resolver para expandir sua produção no Brasil, visando inclusive a mercados externos nos próximos dez anos.

O uso de etanol pode não só reduzir a poluição como também a cana de açúcar extrai da atmosfera o equivalente a $250 \mathrm{~kg} \mathrm{CO}_{2}$ por tonelada de cana plantada.

\begin{tabular}{|c|c|c|}
\hline & \multicolumn{2}{|c|}{$(\mathrm{kg} \mathrm{CO}$ eq. $/ \mathrm{TC})$} \\
\hline & $\begin{array}{l}\text { Scenario } 1 \\
\text { (average) }\end{array}$ & $\begin{array}{c}\text { Scenario } 2 \\
\text { (best values) }\end{array}$ \\
\hline \multicolumn{3}{|l|}{ Type } \\
\hline Fossil fuels & 19.2 & 17.7 \\
\hline Methane and $\mathrm{N}_{2} \mathrm{O}$ from trash buming & 9.0 & 9.0 \\
\hline Soil $\mathrm{N}_{2} \mathrm{O}$ & 6.3 & 6.3 \\
\hline Total emissions & 34.5 & 33.0 \\
\hline \multicolumn{3}{|l|}{ Avoided emissions } \\
\hline Surplus bagasse use & 12.5 & 23.3 \\
\hline Ethanol use & $242.5(\mathrm{~A}) ; 169.4(\mathrm{H})$ & $259.0(\mathrm{~A}): 180.8(\mathrm{H})$ \\
\hline Total avoided emissions & $255.0(\mathrm{~A}) ; 181.9(\mathrm{H})$ & $282.3(\mathrm{~A}) ; 204.2(\mathrm{H})$ \\
\hline Net avoided emissions & $220.5(\mathrm{~A}): 147.4(\mathrm{H})$ & $249.3(\mathrm{~A}): 171.1(\mathrm{H})$ \\
\hline
\end{tabular}

(A): Anhydrous ethanol
(H): Hydrous ethanol

Gráfico 4: Balanço de Emissões

Fonte: Macedo, I et alli, 2004 (Etanol Hidratado) 
O potencial de expansão do álcool no mundo é enorme. Se substituirmos atualmente o consumo de 4milhões $\mathrm{m}^{3} /$ dia de gasolina por etanol, teria 1,4bilhões álcool $\mathrm{m}^{3} / \mathrm{ano}$, correspondendo a 210 milhões ha (atual Brasil: 5,5 milhões ha). Captação de 3,7bi ton $\mathrm{CO}_{2}$ /ano.

De acordo com o autor NASTARI (2004) se fossem adicionados $10 \%$ de álcool em toda gasolina consumida no mundo (20 milhões de barris/dia) seriam necessários 2 milhões de b/d de etanol. O Brasil produz 265 mil b/d, e esta demanda representaria 7,5 vezes a produção do país. Mas, como nem todos os países estão aptos adotar a mistura, considera-se apenas que mistura ocorrerá em $60 \%$ dos blocos mais prováveis, a demanda seria então de 1,08 milhão de b/d: 4 vezes a produção nacional.

GOLDEMBERG, COELHO, LUCON, GUARBADASSI (2005) apresenta comentários sobre a experiência brasileira na adoção do álcool como substituo de combustíveis fosseis. Este projeto foi dimensionado com a crise do petróleo na década de 70 e foi o único grande projeto de sucesso com esse objetivo. O produto destinado a produção de álcool adotado foi a cana de açúcar. O período compreendido é de 30 anos, iniciados a partir de 1975, com a implantação do PROALCOOL. Apresentam algumas vantagens que defendem a adoção do álcool como combustível e, entre elas: desenvolvimento regional, substituição de combustíveis fósseis, diversificação de fontes energéticas, diminuição de poluentes e desenvolvimento de tecnologia nacional.

\begin{tabular}{|l|r|c|}
\hline \multirow{2}{*}{ Países } & \multicolumn{2}{|c|}{ Ano 2004 } \\
\cline { 2 - 3 } & Produçáo de & Potencial de produção \\
\cline { 2 - 3 } & cana-de-açúcar (t) & de etanol (bilhóes de litros) \\
\hline Brasil & 411.009 .984 & 32.880 .799 \\
\hline China & 93.200 .000 & 7.456 .000 \\
\hline Colômbia & 37.100 .000 & 2.968 .000 \\
\hline Cuba & 24.000 .000 & 1.920 .000 \\
\hline República Dominicana & 5.255 .833 & 420.467 \\
\hline Egito & 16.335 .000 & 1.306 .800 \\
\hline Guatemala & 18.000 .000 & 1.440 .000 \\
\hline Índia & 244.800 .000 & 19.584 .000 \\
\hline Indonésia & 24.600 .000 & 1.968 .000 \\
\hline México & 45.126 .500 & 3.610 .120 \\
\hline Paquistão & 52.040 .000 & 4.163 .200 \\
\hline Filipinas & 28.000 .000 & 2.240 .000 \\
\hline África do Sul & 19.291 .800 & 1.543 .344 \\
\hline Tailândia & 63.707 .272 & 5.096 .582 \\
\hline Venezuela & 8.800 .000 & 704.000 \\
\hline
\end{tabular}

Tabela 3: Potencial de produção de etanol e açúcar nos países em desenvolvimento Fonte: FIGUEIRA, 2005 
Dentro desta visão, toma como base de discussão sete pontos importantes:

- Os investimentos privados no setor;

- O balanço energético favorável do etanol;

- A ausência de competição da cana de açúcar com áreas de plantação de alimentos;

- Qualidade dos empregos e impactos sociais;

- Compatibilidade das frotas existentes com a mistura álcool-gasolina;

- A legislação existente é capaz de controlar os impactos ambientais decorrentes;

- Perspectivas de aplicação do programa brasileiro em outros países em desenvolvimento.

Os autores citados acima comentam ainda que todo o processo se iniciou em adotar políticas de subsídios para os já existentes produtores de açúcar com o objetivo de dinamizar e incentivar a produção de álcool em curto espaço de tempo. O resultado de tal política teria que ser rápida para diminuir o impacto na balança da conta petróleo. Desde então, o Brasil teve que isolado do resto do mundo desenvolver uma tecnologia não só de equipamentos, mas também de cultura de cana e processos. O peso do governo em manter estoques de álcool através de compra e subsidio foi obviamente importante que no cenário atual o setor privado vem ganhando peso para direcionar os investimentos e o setor vem sofrendo transformação significativa pelos seguintes motivos:

- Interesse dos demais países no uso de álcool como combustível - exportação Brasil;

- Entrada de grupos estrangeiros;

- Consolidação do setor em grandes produtores;

- Competitividade frente a qualquer país produtor;

- Curva de aprendizado em regime;

- Desenvolvimento de novas tecnologias como biodiesel e flexfuel. 
Alguns problemas ambientais do passado, já foram minimizados, permitindo o desenvolvimento da cana de açúcar com maiores níveis de sustentabilidade.

- O vinhoto que antes era um resíduo descartado nos rios e riachos, hoje se tornou fertilizante;

- As queimadas têm diminuído apesar do aumento da área, pois foi introduzida a colheita mecanizada.

Os autores ainda abordam a questão de replicar o programa do Proálcool em outros países em desenvolvimento, principalmente na África. Permitindo dessa forma o desenvolvimento de uma commodity importante internacionalmente frente aos novos desafios ambientais sem contar na questão social de muitos países pobres.

As possibilidades de aproveitamento do etanol como combustível no Brasil não se esgotam ai, havendo, inclusive, mercado para sua exportação - vários países têm demonstrado interesse no produto. $\mathrm{O}$ apelo ecológico mundial pela substituição dos combustíveis fósseis representa um grande propulsor para o desenvolvimento do álcool como commodity mundial.

A produção de etanol a partir da cana de açúcar, utilizando uma tecnologia não poluente, apresenta as seguintes vantagens:

- incentivará a volta ao campo de contingentes da população, hoje em sub-empregos nas grandes cidades;

- contribuirá para o aumento de rendimento e, portanto, da otimização do uso dos recursos naturais;

- utilizará energia renovável, substituição de combustíveis fosseis, venda de créditos de carbono;

- desenvolvimento da industria de equipamentos no Brasil para fornecimento para o setor.

Apontado como problemas pelos ambientalistas como "invasão" da cana de açúcar em áreas verdes e produtoras de alimentos, os autores mostraram que essa versão não é a realidade e nem mesmo será, pois medidas já foram tomadas para evitar esse tipo de problema no futuro. A expansão da cana será agressiva com a entrada de outros países, mas será limitada pelo uso 
da terra disponível próximas aos grandes centros (SP, MG, PR), além disso, o aumento de produtividade irá permitir otimizar a área atual.

A questão sócio-econômica da cultura da cana de açúcar tem diversos impactos positivos por criar bolsões de riqueza no interior do Estado de São Paulo. Dado o tipo de trabalho, este setor permite incorporar no trabalho formal, diversos trabalhadores considerados pela indústria como "desqualificado", permitindo o uso da mão de obra em condições justas de trabalho. Citado como grande gerador de postos de trabalho frente a outros setores: o baixo investimento necessário para criação de postos de trabalho (US\$ 11/job), em relação à indústria químico-petroquímica (US\$ 220/job).

A visão de alguns economistas de que a exportação de commodities torna o país marginalizado no desenvolvimento de tecnologia de ponta. Isso não é verdade, pois o Brasil poderá desenvolver novos produtos e agregar ao seu potencial agrícola toda uma indústria de máquinas, pesquisas de produtos, desenvolvimento da química final, entre outros.

\section{Mercado Internacional de álcool.}

Tipicamente os maiores mercados consumidores são também os maiores produtores. O Brasil é o principal produtor mundial seguido dos Estados Unidos com produção estimada em 12 bilhões de litros em 2005. A participação dos Estados Unidos é significativamente maior que sua participação no mercado de açúcar, devido a larga utilização do álcool combustível no mercado interno. A Produção mundial concentrada em poucos países e os 5 maiores produtores representam $85 \%$ da produção mundial.

\section{Principais produtores mundiais}

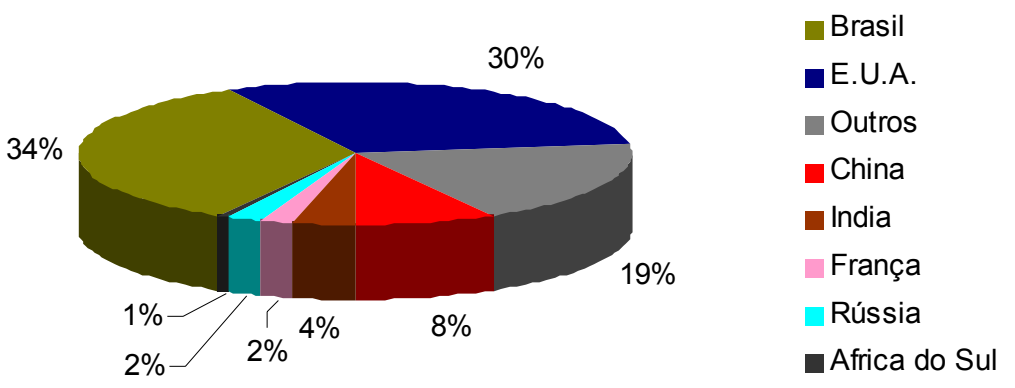


Hoje o maior mercado e concorrente para o álcool brasileiro são os Estados Unidos. O quadro abaixo apresenta o nível de competitividade brasileira na produção do etanol. Enquanto o custo de produção de etanol nos EUA está na faixa dos $\mathrm{R} \$ 250 / \mathrm{m}^{3}$, o Brasil tem um custo de US\$ $170 / \mathrm{m}^{3}$.

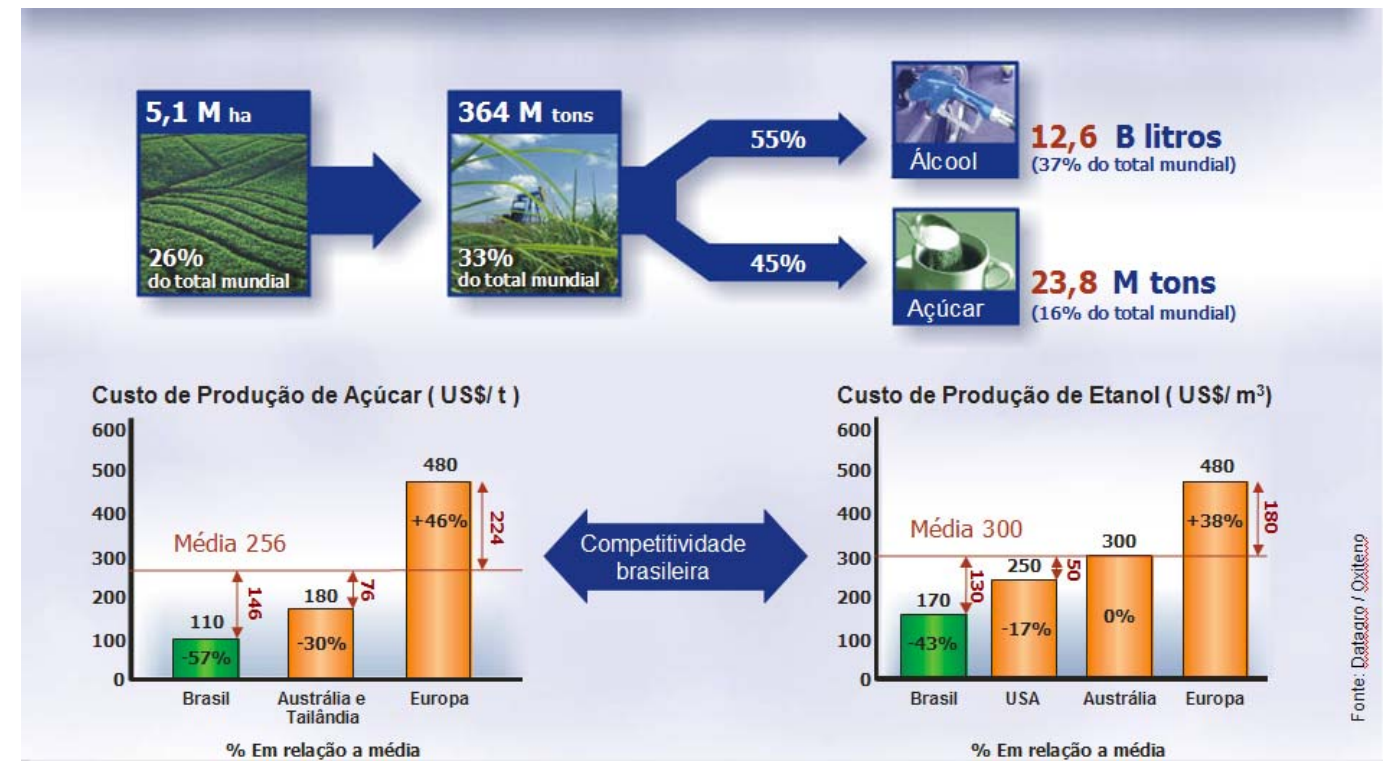

Figura 4: Produção, custo do etanol e do açúcar comparado com mundo 2005.

Fonte: Datagro/Oxiteno

Apesar do setor apresentar mais um importante insumo que é o açúcar e tem grande representatividade nas receitas e volumes de produção. $\mathrm{O}$ trabalho propõe nos restringir apenas nos bicombustíveis.

A produção mundial de álcool vem crescendo fortemente a uma média de $12,2 \%$ ao ano nos últimos 6 anos, com estimativa de produção total de 50 bilhões de litros para a safra 2005/06.

\section{Brasil e o mercado mundial - bilhões de litros}

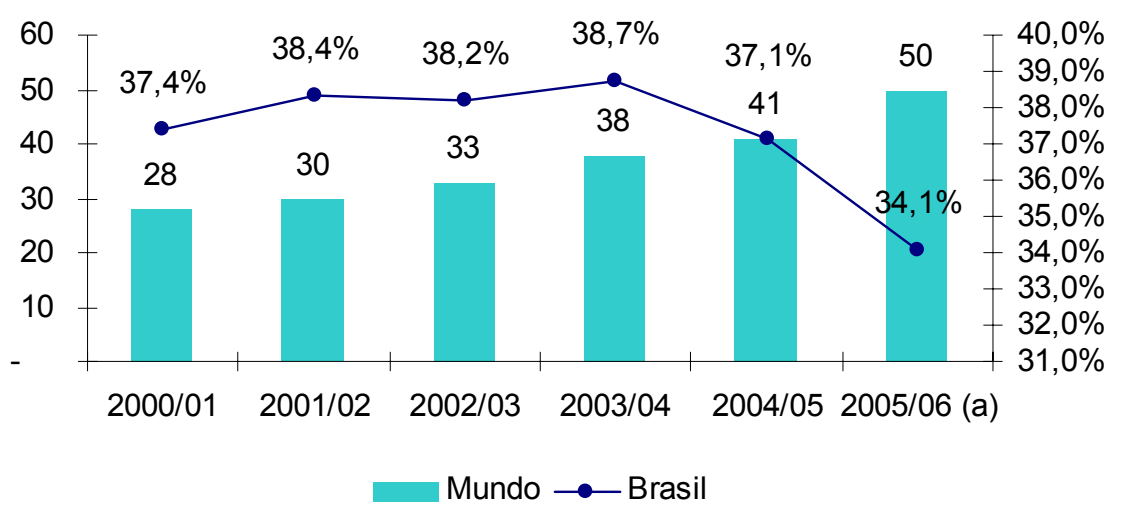

Gráfico 6 - Participação do álcool brasileiro

Fonte: F.O. Licht / MAPA / Conab - 2005/06 estimativas 
Apesar da expectativa de diminuição da representatividade do Brasil no mercado mundial na safra 2005/06, com 34\% da produção mundial, abaixo dos patamares históricos entre $37 \%$ e $38 \%$, o Brasil continua sendo o principal produtor mundial com mais de um terço da produção.

\section{Produção agrícola e produtividade}

Os gráficos abaixo apresentam a evolução histórica dos níveis de produção e da produtividade agrícola do setor sucroalcooleiro no Brasil.

\section{Produtividade - toneladas por hectare}

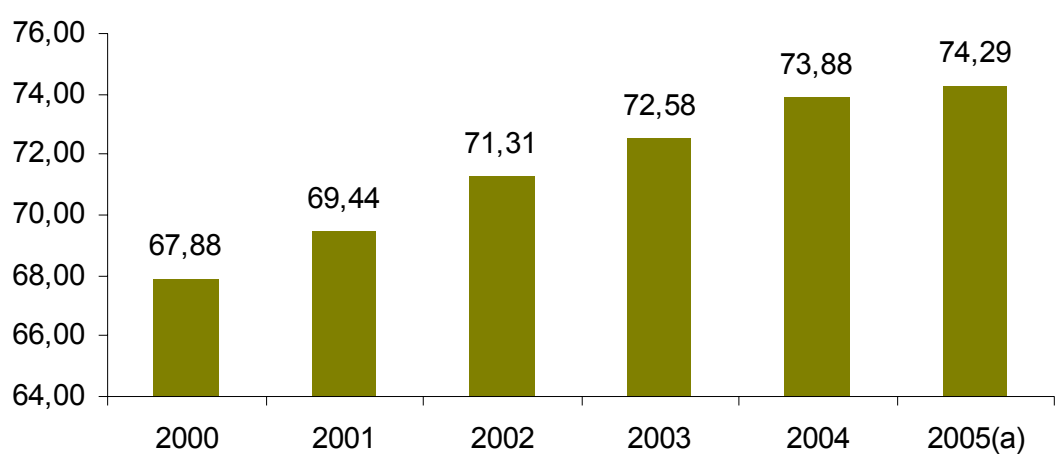

Produção - milhares de toneladas de cana

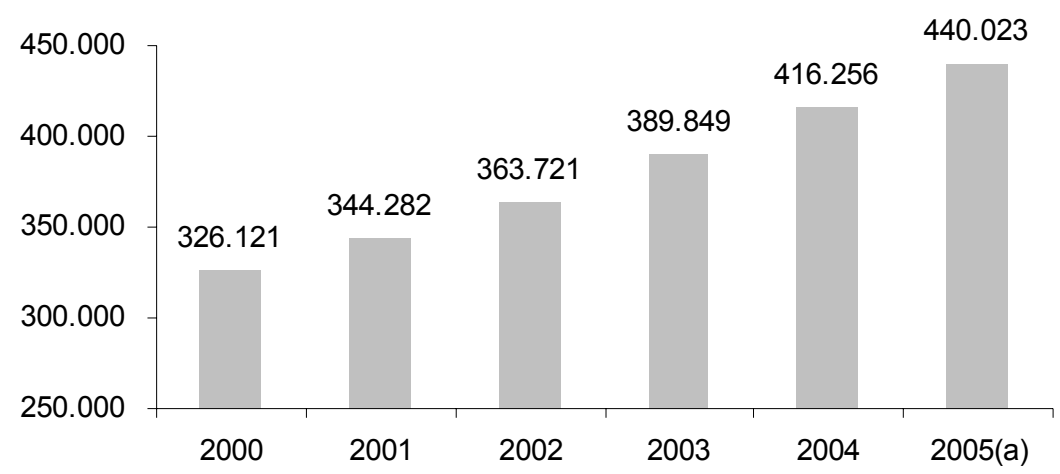

Gráfico 7 - Produção e Produtividade da cana-de-açúcar no Brasil.

Fontes: Conab / IBGE - (a) estimativa

O setor sucroalcooleiro brasileiro vem demonstrando crescimento considerável, atingindo crescimento médio anual de $6 \%$ nos volumes de cana processada entre 2000 e 2005 . O setor sucroalcooleiro brasileiro apresentou crescimento médio de $1,8 \%$ no nível de produtividade agrícola entre 2000 e 2005. 
A produção nacional aumentou de 416 milhões de toneladas em 2004/05 para 440 milhões de toneladas em 2005/06, apresentando crescimento de 6\%. A área destinada à produção cresceu de 5,6 milhões de hectares em 2004/05 para 5,9 milhões de hectares em 2005/06.

A região Centro-Sul é responsável pela maior parte da produção nacional, 375 milhões de toneladas, representando $85 \%$ da produção nacional, enquanto a região Norte-Nordeste produz 65 milhões de toneladas ou 15\% da produção nacional, sendo São Paulo é o Estado que concentra maior parte da produção nacional, 262,9 milhões de toneladas, ou 59,7\%

\section{Produção nacional - distribuição geográfica}

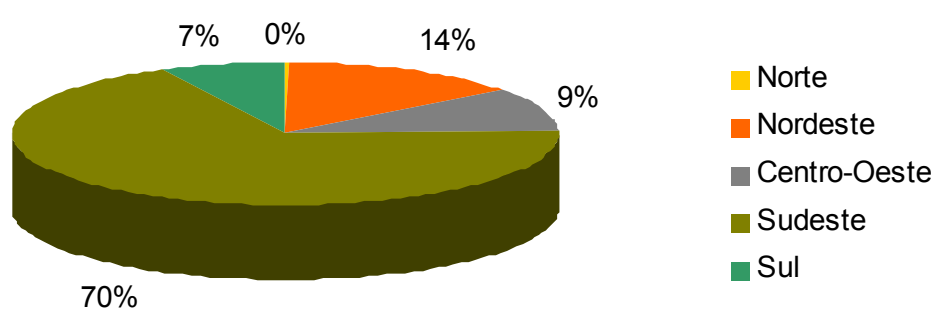

Gráfico 8 - Produção Nacional de Cana-de-açúcar.

Fontes: Conab / IBGE - safra 2005/06, estimativa

A produção nacional aumentou de 15 bilhões de litros em 2004/05 para 17 bilhões de litros em 2005/06, apresentando $12 \%$ de crescimento, acima do crescimento da produção de cana e do açúcar, resultado do maior direcionamento da produção para o álcool nas últimas safras.

A região Centro-Sul foi responsável por $89 \%$ do total da produção nacional de álcool enquanto a região Norte-Nordeste foi responsável por 11\%. São Paulo é o Estado que concentra maior parte da produção nacional. As usinas de São Paulo produziram um total de 10,4 bilhões de litros na safra 2005/06, ou $61 \%$ da produção nacional.

Em relação ao mercado total existe um direcionamento maior da produção nas usinas das regiões Centro-Oeste e Sul para o álcool e nas usinas da região Nordeste para o açúcar.

O Brasil é o principal player neste mercado por apresentar condições favoráveis: tecnologia, condição geográfica, áreas ociosas e mercado. Abaixo o gráfico apresenta o potencial de crescimento do álcool no Brasil. 


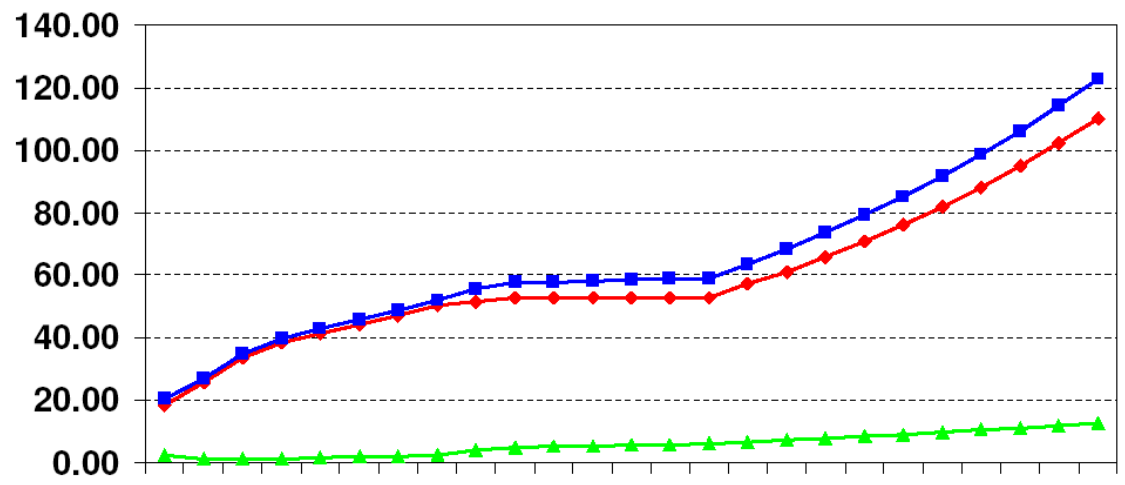

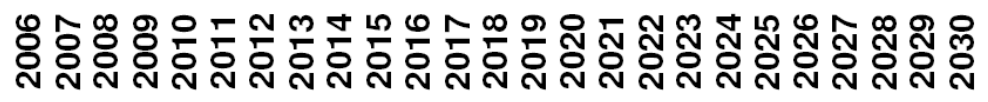

$\rightarrow$ Produção $\rightarrow$ Demanda $\quad$ Importações

Gráfico 9 - Projeção do mercado de álcool no Brasil Fonte: Unica

O Brasil utiliza 25\% de álcool na gasolina e ao longo destes 30 anos permitiu desenvolver uma tecnologia única nos veículos, além disso, a tecnologia flex-fuel tem se tornado uma realidade na indústria de veículos brasileira. Estes dois pontos citados demonstram que o álcool como combustível já se tornou uma realidade nacional.

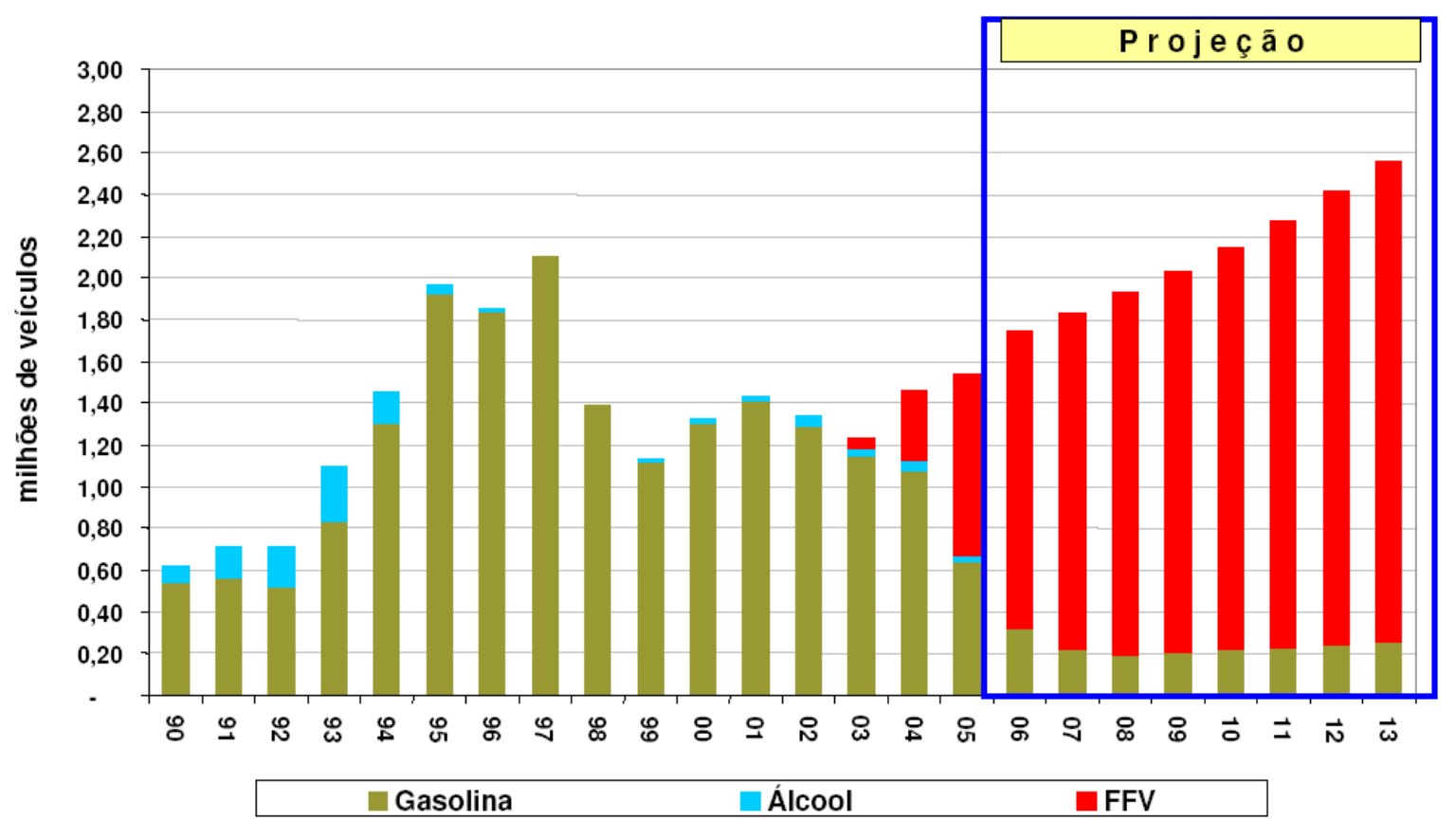

Gráfico 10 - Projeção da produção de veículos flex

Fonte: Anfavea

Na tabela abaixo apresenta a situação atual da indústria de álcool no Brasil na safra 2006/2007 e a seguir 2012/2013. 


\begin{tabular}{|c|c|c|c|}
\hline & \multicolumn{2}{|c|}{ REGIŌES } & \multirow[b]{2}{*}{ BRASIL } \\
\hline PARÂMETROS & CENTRO-SUL & N/NORDESTE & \\
\hline Número de unidades em operação & 251,0 & 74,0 & 325,0 \\
\hline Área a ser colhida(mil ha) & 4.513 .7 & 854.8 & 5.368 .5 \\
\hline Área cultivada (mil ha) & $5.310,2$ & $1.005,7$ & $6.315,9$ \\
\hline Oferta de cana (milhões de t) & 372,4 & 53,0 & 425,4 \\
\hline Produtividade Agrícola (t/ha) & 82,5 & 62,0 & 79,2 \\
\hline Produção de Açúcar (milhões t) & 25,8 & 4,0 & 29,8 \\
\hline Produção de Álcool (mil m³) & 16,0 & 1,7 & 17,7 \\
\hline Produção em ATR-produto (milhões t) & 54,7 & 7,1 & 61,8 \\
\hline ATR/t cana & 146,9 & 134,7 & 145,4 \\
\hline \multicolumn{4}{|l|}{ Mix de produção - \% } \\
\hline Açúcar & $49,51 \%$ & $58,80 \%$ & $50,58 \%$ \\
\hline Álcool & $50,49 \%$ & $41,20 \%$ & $49,42 \%$ \\
\hline Cap. média de moagem tc/safra & $1.483,6$ & 716,2 & $1.308,9$ \\
\hline \multicolumn{4}{|l|}{ Mercado Externo } \\
\hline .Açúcar & 17,0 & 2,6 & 19,6 \\
\hline Álcool & 3,2 & 0,4 & 3,6 \\
\hline \multicolumn{4}{|l|}{ Mercado Interno } \\
\hline .Açúcar & 8,5 & 1,5 & 10,0 \\
\hline Álcool & 13,0 & 1,0 & 14,0 \\
\hline Excedente & $-0,2$ & 0,3 & 0,1 \\
\hline \multicolumn{4}{|l|}{ Destinação da produção (\%) } \\
\hline Mercado interno & $57,28 \%$ & $52,11 \%$ & $56,68 \%$ \\
\hline Mercado externo & $42,72 \%$ & $47,89 \%$ & $43,32 \%$ \\
\hline
\end{tabular}

Tabela 4 - Setor de açúcar e álcool 2006/2007

Fonte: Unica

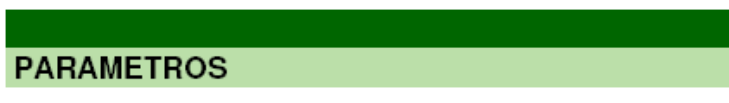

REGIŌES

.Número de unidades em operação

.Área a ser colhida(mil ha)

Área cultivada (mil ha)

Oferta de cana (milhões de t)

Produtividade Agrícola (t/ha)

Produção de Açúcar (milhões t)

Produção de Álcool (mil m³)

.Produção em ATR-produto (milhões t)

ATR/t cana

.Mix de produção - \%

$$
\text { .Açúcar }
$$

Cap. média de moagem tc/safra

\section{Mercado Externo}

.Açúcar

.Álcool

.Mercado Interno

.Açúcar

.Álcool

Excedente

.Destinação da produção (\%)

Mercado interno

Mercado externo

\section{CENTRO-SUL N/NORDESTE}

337,0

$7.856,2$

$9.242,6$

667,8

85,0

34,0

36,0

97,8

146,5

$36,48 \%$

$63,52 \%$

$1.981,5$

24,0

5,0

10,0

25,3

5,7

$65,43 \%$

$34,57 \%$
75,0

923,1

$1.086,0$

60,0

65,0

4,5

2,0

8,2

136,4

BRASIL

BRASIL

412,0

$8.779,3$

$10.328,6$

727,8

82,9

38,5

38,0

106,0

145,7

$38,12 \%$

$61,88 \%$

$1.766,4$

$42,28 \%$

800,0

27,0

0,5

5,5

11,5

26,5

6,0

1,2
0,3

$64,31 \%$ $35,69 \%$

Tabela 5 - Setor de açúcar e álcool ano 2012/2013

Fonte: Unica 


\section{O mercado potencial para exportação}

O uso da biomassa pelo Brasil poderá colocar o país como um grande exportador de tecnologia e novos produtos. Na questão do álcool, muitos produtos derivados deverão surgir no mercado, pois há uma grande indústria química a ser desenvolvida.

$\mathrm{Na}$ tabela abaixo, um resumo dos eventos que vem ocorrendo no mundo e pode apresenta o Brasil como o maior parceiro para atender estas mudanças na matriz energética de diversos países em destaque:

\begin{tabular}{|c|c|c|c|}
\hline Países & $\begin{array}{l}\text { Demanda } \\
\text { Potencia } \\
\text { bi. litros }\end{array}$ & $\begin{array}{c}\text { Mistura } \\
\text { de álcool } \\
\%\end{array}$ & Observaçōes \\
\hline JAPÃO & 1,8 & $3 \%$ & $\begin{array}{l}\text { Potencial E3 ; E10 } \longrightarrow 6,0 \text { bi } \\
\text { Meta 2008: } 7 \% \text { ETBE em } 30 \% \text { da gasolina: } 0,4 \text { bi }\end{array}$ \\
\hline E.U.A. & 28,4 & & $\begin{array}{l}\text { mínimo para } 2.012 \text { na RFS em aprovação no Senado; } \\
\text { máximo de mistura permitida é de } 5,7 \% \text {; } \\
7 \% \text { duty free via Caribe ( } 908,4 \text { base } 2004 \text { ) }\end{array}$ \\
\hline CHINA & 4,8 & $10 \%$ & $\begin{array}{l}\text { PotencialE10 nivel nacional; vigente apenas em provincias } \\
\text { Produz } 1,8 \text { para bebida e ind }+0,75 \mathrm{p} / \mathrm{E} 10 \\
0,7 \text { milho }+0,2 \text { mandioca }+0,1 \text { melaço } \\
\text { demanda de } 8 \text { bi } 2012(4,8 \text { E10 }+ \text { bebidas e ind })\end{array}$ \\
\hline U.E. & 7,4 & $5 \%$ & $\begin{array}{l}\text { Potencial de álcool em adição de } 5 \% \text { em toda gasolina } \\
\text { em } 2011 \text {, limite permitido pela Diretiva Européia dentre os } \\
5,75 \% \text { de biocombustiveis. }\end{array}$ \\
\hline ÍNDIA (1) & 1,07 & $10 \%$ & $\begin{array}{l}\text { Em } 3 \text { fases, com retomada em dez 2005: E5 em } 9 \text { est }+4 \\
\text { unióes; E5 país e E10 país }(0,340 / 0,535 / 1,070 \text { bi })\end{array}$ \\
\hline TAILÂNDIA (2) & 1,0 & $5 \%$ & $\begin{array}{l}\text { Potencial para 2007; Lançado em 2001; extinção do } \\
\text { ETBE em maio/04: várias blantas etanol autorizadas }\end{array}$ \\
\hline FILIPINAS (2) & 0,35 & $10 \%$ & Potencial para 2010; E5 em $2007=0,16$ bi \\
\hline AUSTRÁLIA (2) & 2,1 & $10 \%$ & E10 potencial; Meta para 2010 projetada para 0,35 bi \\
\hline
\end{tabular}

(1) Nos Estados Unidos, a mistura de 5,7\% em toda a gasolina significa consumo de 30 bilhões de litros de álcool/ano.

Tabela 6: Mercado Potencial de Álcool.

Fonte: EIA/DOE; Comissão Européia.

Abaixo cenários propostos pela FAO para o futuro do álcool.

\section{Cenário 1:}

O Cenário 1 utilizou dados da FAO referentes à área colhida, produtividade agrícola e produção de cana-de-açúcar. 
A partir destes dados será proposto o deslocamento de $10 \%, 20 \%$ e $50 \%$ da produção de cana para a produção de etanol.

Neste cenário não é prevista a ampliação da área plantada, nem o aumento da eficiência agrícola, ou dos processos produtivos.

\section{Cenário 2:}

O Cenário 2 utilizou os resultados obtidos pelo "Global Agro-Economic Zones (GAEZ)", estudo realizado pela FAO e pelo IIASA (International Institute for Applied Systems Analysis) que determinou a potencialidade agrícola dos países para 27 culturas (soja, batata, milho, cana-de-açúcar, trigo etc). Este estudo utilizou como base o mapeamento digital do solo mundial (Digital Soil Map of the World - DSMW) (FAO, UNESCO) combinado com dados ambientais, condições climáticas, qualidade dos terrenos e índices agrícolas.

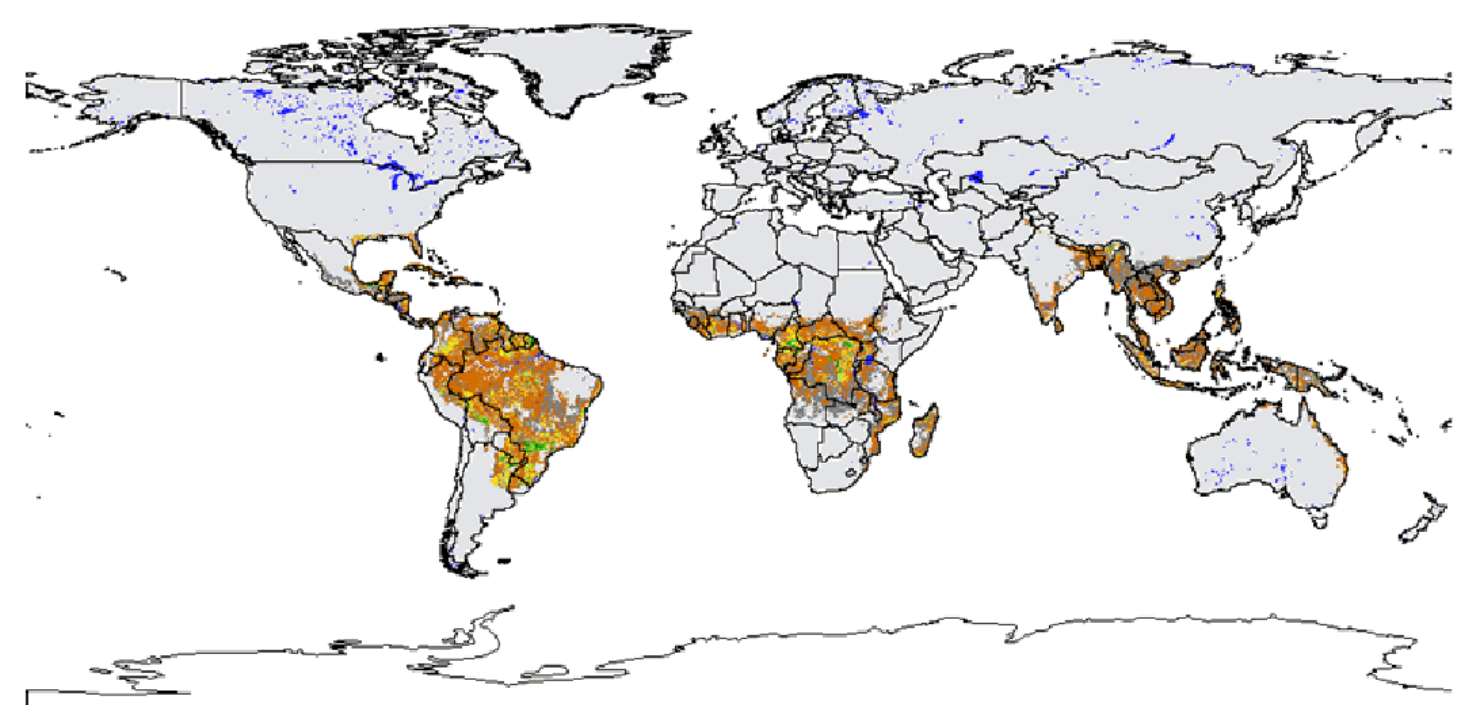

Figura 5: Mapeamento de possíveis áreas para o desenvolvimento da cana-de-açucar Fonte: DSMW, (FAO, UNESCO). 


\begin{tabular}{|c|c|c|c|c|c|}
\hline & \multirow[b]{2}{*}{$\begin{array}{c}\text { Consumo de } \\
\text { gasolina } \\
\left(\mathrm{m}^{3}\right)\end{array}$} & \multirow[b]{2}{*}{$\begin{array}{c}\text { Volume de etanol } \\
\text { necessário para E10 }\end{array}$} & \multicolumn{3}{|c|}{ Volume disponível } \\
\hline & & & $\begin{array}{c}10 \% \text { da } \\
\text { produção } \\
\text { atual de cana } \\
\left(\mathrm{m}^{3}\right)\end{array}$ & $\begin{array}{c}20 \% \text { da } \\
\text { produção } \\
\text { atual de cana } \\
\left(\mathrm{m}^{3}\right)\end{array}$ & $\begin{array}{c}50 \% \text { da } \\
\text { produção } \\
\text { atual de cana } \\
\qquad\left(\mathrm{m}^{3}\right)\end{array}$ \\
\hline África & 35.325 .150 & 3.532 .515 & 697.269 & 1.394 .537 & 3.486 .343 \\
\hline Ásia & 112.208 .946 & 11.220 .895 & 4.752 .678 & 9.505 .357 & 23.763 .391 \\
\hline $\begin{array}{l}\text { América Latina } \\
\text { e Caribe }\end{array}$ & 64.654 .531 & 6.465 .453 & 4.653 .759 & 9.307 .519 & 23.268 .797 \\
\hline Mundo & 1.171 .797 .242 & 117.179 .724 & 10.103 .706 & 20.207 .412 & 50.518 .530 \\
\hline
\end{tabular}

Nota: não há dados disponíveis referentes ao consumo de gasolina para 2002, logo optou-se por aplicar a taxa de crescimento observada entre 2000 e 2001, projetando o valor para 2002. Fonte: IEA (2003)

Tabela 7: Cenário 1

Fonte: IEA

\begin{tabular}{|c|c|c|c|c|c|}
\hline & \multirow[b]{2}{*}{$\begin{array}{c}\text { Consumo de } \\
\text { gasolina }\end{array}$} & \multirow[b]{2}{*}{$\begin{array}{c}\text { Volume de etanol } \\
\text { necessário para E10 }\end{array}$} & \multicolumn{3}{|c|}{ Volume disponível } \\
\hline & & & $\begin{array}{c}10 \% \text { do } \\
\text { potencial de } \\
\text { produção } \\
\left(\mathrm{m}^{3}\right)\end{array}$ & $\begin{array}{c}20 \% \text { do } \\
\text { potencial de } \\
\text { produção } \\
\left(\mathrm{m}^{3}\right)\end{array}$ & $\begin{array}{c}50 \% \text { do } \\
\text { potencial de } \\
\text { produção } \\
\left(\mathrm{m}^{3}\right)\end{array}$ \\
\hline África & 35.325 .150 & 3.532 .515 & 129.442 .878 & 258.885 .755 & 647.214 .388 \\
\hline Ásia & 112.208 .946 & 11.220 .895 & 61.584 .269 & 123.168 .537 & 307.921 .343 \\
\hline $\begin{array}{l}\text { América Latina } \\
\text { e Caribe }\end{array}$ & 64.654 .531 & 6.465 .453 & 243.009 .267 & 486.018 .533 & 1.215 .046 .334 \\
\hline Mundo & 1.171 .797 .242 & 117.179 .724 & 434.036 .413 & 868.072 .826 & 2.170 .182 .065 \\
\hline
\end{tabular}

Nota: não há dados disponíveis referentes ao consumo de gasolina para 2002, logo optou-se por aplicar a taxa de crescimento observada entre 2000 e 2001, projetando o valor para 2002. Fonte: IEA (2003)

Tabela 8: Cenário 2

Fonte: IEA (2003)

\subsubsection{Carvão Vegetal}

O Brasil apresenta 106 milhões ha em terras disponíveis, mais áreas de pastagens de 220 milhões de ha que poderiam ser convertidos em florestas. Hoje o Brasil possui 5milhões ha reflorestamento ( $62 \%$ eucaliptos).

Florestas brasileiras crescem $40 \mathrm{~m} / \mathrm{ha} /$ ano enquanto países como Chile, Argentina 25 $\mathrm{m}^{3} /$ ha/ano. O clima tropical/subtropical: favorece crescimento do eucalipto: Brasil (7 anos); 
África do Sul e Chile (12 anos), Espanha (15 anos). Como pode ser verificado no gráfico abaixo.

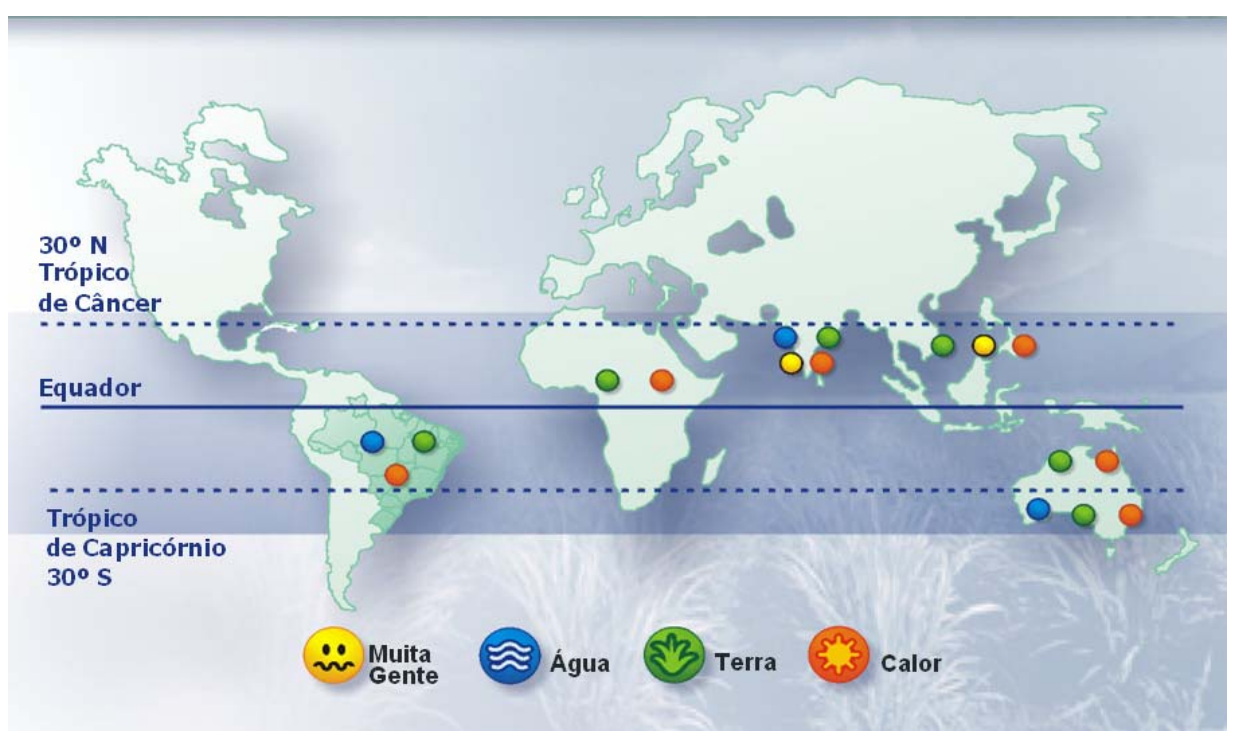

Figura 6: Competitividade Internacional - Vantagens naturais Brasil Fonte: FAO, 2000

Vem ocorrendo transferência do setor florestal para a América do Sul com destaque para o Brasil, África e Sudeste Asiático. Abaixo gráfico apresenta o volume anual em expansão.

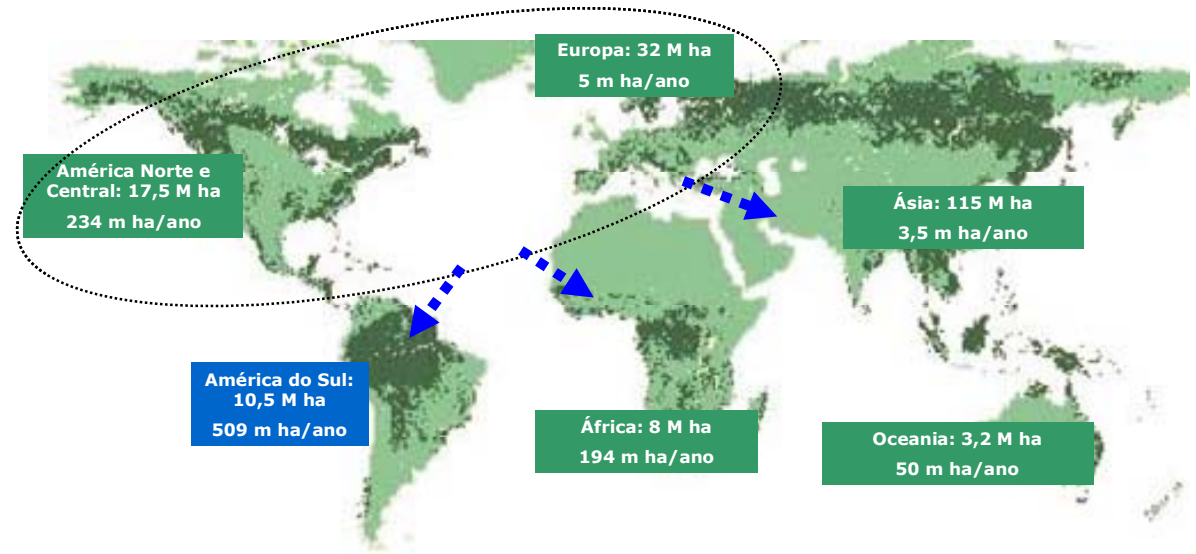

Figura 7: Transferência do setor florestal Fonte: FAO, 2001

Uso da madeira para fins energéticos embrionária no Brasil com grande potencial para o futuro. (atualmente 1,2 milhões ha de terras para uso siderúrgico).

O carvão vegetal é hoje no Brasil uma matéria prima de importância estratégica, pois dele dependem: boa parte da indústria siderúrgica, a produção de silício metálico, a produção de ligas de manganês e também várias indústrias químicas. As possibilidades de aproveitamento 
do carvão vegetal como matéria-prima não se esgota ai, sendo fonte de carbono sem impurezas, havendo, inclusive, mercado para sua exportação.

Algumas empresas que usam o carvão vegetal têm produção própria, trabalhando com tecnologia bastante rudimentar e com florestas próprias, insuficientes para a produção do aço, buscando solução no mercado que hoje é incapaz de atendê-los dentro de modelos sustentáveis de modelos ecológicos, sociais e econômicos.

A maioria do carvão é produzida de maneira artesanal, com tecnologias do século retrasado, que provocam altas perdas, poluição· e devastação clandestina de florestas naturais. Além disso, sua produção é intermitente, sendo interrompida com as chuvas ou alta demanda de mão de obra em outras atividades, como, por exemplo, colheitas agrícolas.

No entanto, o mercado consumidor, apesar da crise atual, já se tem dado conta da precariedade do abastecimento de carvão e está ciente de que, certamente, o crescimento do setor será comprometido pela falta deste abastecimento, o uso do carvão vegetal teve redução nos últimos anos, sendo substituído por carvão mineral importado.

Não bastasse isso, o país possui inúmeras vantagens para o desenvolvimento deste setor: como disponibilidade de áreas para cultivo e água, condições atmosférica favoráveis, mercado consumidor e forte expansão da siderurgia.

O Brasil importou em 2004 aproximadamente 12 milhões de toneladas de carvão mineral para uso siderúrgico a um preço médio de FOB US\$125,00/ton. Estes valores representam 14,3\% dos minerais não metálicos importados em 2005.

A região sul do Brasil principalmente o estado de Santa Catarina apresenta jazidas de carvão mineral, porém o seu uso é desaconselhável para o setor siderúrgico dado o seu alto grau de enxofre que torna a qualidade do aço de baixa qualidade.

Existe a necessidade de uma "oferta regular" que irá induz muitas empresas a substituir o carvão mineral pelo carvão vegetal, visando abastecer-se no mercado. Formar-se-á, dessa maneira, um mercado de "demanda livre".

Repousa sobre a substituição do uso de combustíveis fósseis o principal apelo da utilização do carvão vegetal dentro do processo industrial de aço. Entretanto, este aspecto deve ser 
analisado dentro de uma amplitude maior, envolvendo de maneira equânime as questões sócio-econômicas e ecológicas da alternativa.

Obviamente, a análise econômica desta alternativa energética é de fundamental importância, pois demonstra sua viabilidade frente aos agentes financiadores e partes interessadas. Contudo, o que dizer das demais variáveis envolvidas? Qual o impacto da atividade sobre outras questões relevantes e adjacentes?

O emprego de mão-de-obra nas usinas de produção, bem como a necessidade de profissionais nas culturas de produção da madeira, são aspectos de interesse com relação à geração de empregos. Estima-se que uma usina de produção possa gerar cerca de 200 empregos diretos. Somando-se a este montante os empregos indiretos que possibilitarão a sustentação do negócio, temos idéia do potencial de fixação no campo proporcionado pela atividade.

Assumindo este viés de potencialidade para fixação do homem no campo e emprego de mãode-obra semi-qualificada e também trabalhadores qualificados, temos que a atividade silvoquímica pode ser interessante como fator motivador do desenvolvimento de determinada região.

As questões relativas ao processamento (pós-cultivo) não são citados, pois constituem processos ordinários de licenciamento, já perfeitamente absorvidos e praticados pelos diversos órgãos ambientais. Parece-nos mais importante ressaltar que a cultura deve também ser objeto do "acompanhamento" dos órgãos de meio ambiente.

\subsubsection{Biogás}

Os processos de fermentação anaeróbia que produzem metano foram, desde sempre, utilizados pelo homem para o tratamento dos esgotos, nos sistemas conhecidos por "fossas sépticas". Estas serviam para tratar os esgotos domésticos de pequenas comunidades, resíduos da indústria agro-alimentar ou agropecuária. Com o passar dos tempos, estes sistemas simplificados de tratamento evoluíram. No final do século passado, os chamados "digestores" começaram a ser utilizados, para efetuar a estabilização das lamas resultantes da sedimentação primária e do tratamento biológico aeróbio dos esgotos. 
Os primeiros países a utilizarem o processo de biodigestão intensivamente e com o com o intuito de produzir energia foram a China e a Índia, nas décadas de 50 e 60. Esses países, e outros do terceiro mundo, desenvolveram seus próprios modelos de biodigestores (NOGUEIRA, 1986).

No Brasil, até há pouco tempo, o biogás era simplesmente um subproduto, obtido a partir da decomposição anaeróbica de lixo urbano, resíduos animais e de lamas provenientes de estações de tratamento de efluentes domésticos. No entanto, o acelerado desenvolvimento econômico dos últimos anos, o aumento do preço dos combustíveis convencionais e as oportunidades criadas pelo Protocolo de Quioto têm encorajado as investigações na produção de energia a partir de novas fontes alternativas e economicamente atrativas.

Atribui-se o nome de biogás à mistura gasosa, combustível, resultante da fermentação anaeróbica da matéria orgânica. A proporção de cada gás na mistura depende de vários parâmetros, como o tipo de digestor e o substrato a digerir. De qualquer forma, esta mistura é essencialmente constituída por metano $\left(\mathrm{CH}_{4}\right)$ e por dióxido de carbono $\left(\mathrm{CO}_{2}\right)$, estando o seu poder calorífico diretamente relacionado com a quantidade de metano existente na mistura gasosa, sendo que a presença de substâncias não combustíveis, como água e dióxido de carbono, prejudica o processo de queima, tornando-o menos eficiente, uma vez que presentes na combustão absorvem parte da energia gerada (ALVES, 2000).

O biogás por ser extremamente inflamável, oferece condições para duas situações possíveis de aproveitamento. O primeiro caso consiste na queima direta para produção de calor (cocção, aquecimento ambiental etc). O segundo caso diz respeito à conversão de biogás em eletricidade. Assim, os sistemas que produzem o biogás, podem tornar a exploração pecuária auto-suficiente em termos energéticos, assim como contribuir para a resolução de problemas de poluição de efluentes.

Depois de passarem no digestor, os resíduos restantes apresentam alta qualidade para uso como fertilizante agrícola.

A demanda por projetos de aproveitamento de biogás está crescendo principalmente devido às oportunidades oferecidas pelo Mecanismo de Desenvolvimento Limpo do Protocolo de Quito. Nos aterros sanitários, todos os resíduos acumulados ficam expostos ao ar livre, e o gás metano produzido pela decomposição aeróbia destes resíduos é liberado na atmosfera. 
Assim, a utilização do biogás para geração de eletricidade é uma atividade que pode obter os Certificados de Emissões Reduzidas, os chamados “créditos de carbono". Infelizmente, alguns projetos submetidos ao conselho responsável pela aprovação dos projetos de MDL (Executive Board) apenas irão queimar o metano em "flare", substituindo as emissões de metano por dióxido de carbono.

O primeiro projeto de utilização de biogás de aterro aprovado pelo Comitê Executivo para receber os "créditos de carbono" foi o Aterro Nova Gerar, em Nova Iguaçu, Rio de Janeiro. O projeto utilizará o biogás produzido pelo antigo "lixão" de Marambaia, que foi substituído por um aterro sanitário totalmente controlado, o Aterro de Adrianópolis, e deverá gerar $12 \mathrm{MW} \mathrm{e}$ evitará a emissão de 14 milhões de toneladas de $\mathrm{CO}_{2}$ em 21 anos (ECOSECURITIES, 2004).

Um outro problema é a escassez de energia em propriedades rurais, localidades de difícil acesso e comunidades isoladas. A suinocultura, por exemplo, é uma atividade predominante de pequenas propriedades rurais, com importantes conseqüências do ponto de vista social e econômico, como geração de emprego, renda e fixação do homem no campo.

Segundo dados do IBGE, o abate de suínos entre janeiro de 1997 e janeiro de 2005 cresceu cerca de $45 \%$, junto esse aumento da quantidade de suínos produzidos há o crescimento de dejetos e os impactos ambientais associados. Estima-se que um suíno adulto produza cerca de $0,27 \mathrm{~m}^{3}$ de dejetos líquidos por mês.

\subsubsection{Biomassa como fonte de Energia Elétrica}

O aproveitamento da madeira como fonte de energia pode ser considerada a forma mais antiga de utilização de biomassa, pois a partir dela é produzida a lenha, ainda hoje empregada para cocção e calefação.

A energia gerada empregando-se a madeira e/ou seus resíduos é denominada dendroenergia, podendo a madeira utilizada como combustível ser proveniente de florestas energéticas ou processos industriais (NOGUEIRA; LORA, 2003).

A exploração de florestas plantadas visa exclusivamente a conversão da madeira em energia. Caso a madeira seja proveniente de florestas nativas deve-se, obrigatoriamente, considerar um 
sistema de reflorestamento ou manejo, visando garantir a sustentabilidade do processo de exploração florestal (VARKULYA JR, 2004).

Três segmentos industriais que usam madeira podem ser destacados: papel e celulose, serrarias e movelarias, sendo que a madeira utilizada para produção de energia deriva dos próprios processos industriais.

O setor de papel e celulose é dividido em três grupos: indústrias de papel, indústrias de celulose e indústrias integradas (fabricantes de papel e celulose). A geração de eletricidade empregando resíduos de madeira é mais acentuada nas indústrias de celulose e nas integradas, pois nestes grupos ocorre o processamento da madeira, que é a matéria para produção de celulose. Nessas unidades a produção de energia atende de $50 \%$ a $80 \%$ da demanda interna, já as unidades que fabricam apenas papel geram apenas $10 \%$ da energia consumida no processo, comprando o restante das concessionárias (VELÁZQUEZ, 2000). Algumas unidades produtoras vendem excedente para a rede, como é o caso da CENIBRA, que desde 2001 deixou de comprar energia da concessionária e passou a vender cerca de $200 \mathrm{MWh} / \mathrm{dia}$ (VELAZQUEZ, 2005).

A madeira aproveitada para a geração de energia deriva das cascas e aparas das árvores processadas. Ainda pode ser considerado, neste segmento, um outro tipo de biomassa denominado lixívia ou licor negro, obtido através do processo de cozimento da madeira para produção de celulose, denominado processo sulfato ou "kraft” (VELÁZQUEZ, 2000).

Analogamente ao setor sucroalcooleiro, o vapor obtido na caldeira, a partir da queima de resíduos de madeira, além de gerar eletricidade capaz de atender parte do consumo da própria indústria, também pode atender às necessidades térmicas da planta industrial.

Os resíduos agrícolas são importantes fontes de energia, e servem de combustível para geração descentralizada de calor e trabalho. As fontes com participação mais significativa são

O bagaço de cana-de-açúcar é a biomassa de maior representatividade na matriz energética brasileira, sendo responsável pelo suprimento de energia térmica, mecânica e elétrica das unidades de produção de açúcar e álcool.

Após a colheita, a cana-de-açúcar é encaminhada à usina, lavada para retirar terra, pedras areia e outros materiais indesejados, e segue para o processo de preparo no qual passa por um desfibrador cuja finalidade é aumentar a densidade e a abertura das células do colmo de cana, 88 
otimizando a quantidade de caldo que pode ser extraído. Depois do preparo a cana é enviada ao conjunto de moendas onde é retirado o caldo no qual o açúcar encontra-se dissolvido. Os produtos desse processo físico são o caldo, cujo rendimento de extração varia de $92 \%$ a $97 \%$, e o bagaço com teor de umidade final de aproximadamente $50 \%$ (base úmida).

Após a extração do caldo, o bagaço de cana é constituído de $46 \%$ de fibra, $50 \%$ de umidade e $4 \%$ de sólidos dissolvidos. São obtidos de $240 \mathrm{~kg}$ a $280 \mathrm{~kg}$ de bagaço por tonelada de cana moída (MACEDO; CORTEZ, 2005). O teor energético de bagaço é de 30\% a 40\% da energia total da planta (BRAUNBECK; CORTEZ, 2005).

O bagaço é então encaminhado à caldeira, o vapor de alta/média pressão é utilizado para acionar as turbinas a vapor, que por sua vez produzem energia mecânica para o acionamento das moendas, desfibradores, turbo-bombas e geradores elétricos. $\mathrm{O}$ vapor de baixa pressão é utilizado como fonte de energia térmica, nos processo produtivos do açúcar e também do álcool.

Durante muitos anos, desde o início do Proálcool, o bagaço de cana era tido com um subproduto indesejado. Produzido em grandes quantidades e de difícil armazenagem, a queima do bagaço nas caldeiras foi adotada não apenas como uma solução energética. Neste período as caldeiras das usinas eram reguladas de forma a queimar a maior quantidade de bagaço possível, nesta época a grande abundância de energia hidrelétrica levava a uma legislação que praticamente impedia a vende de excedentes de energia para a rede (MACEDO, 2005).

Essa realidade começou a mudar no ano de 2001, quanto o Brasil foi afetado por uma grave crise de abastecimento de energia. Nesse momento, em que os preços da eletricidade atingiram valores nunca vistos, alguns produtores do setor sucroalcooleiro que já produziam excedente de eletricidade, perceberam o nicho de mercado existente.

Desde então, muitas usinas estão trocando seus equipamentos obsoletos por outros mais eficientes (caldeiras de 60 bar a 80 bar e turbinas de contrapressão), com o intuito de produzir excedente de eletricidade a ser comercializado.

De acordo com dados da União da Agroindústria Canavieira (UNICA, 2005) atualmente a potência instalada para geração a partir de bagaço de cana é de $3.500 \mathrm{MW}$, dos quais $700 \mathrm{MW}$ estão sendo vendidos para as concessionárias de energia. A previsão do setor é de que na safra 
2009/2010 sejam produzidos 560 milhões de toneladas de cana, um crescimento de cerca de $45 \%$, e que a potência instalada no setor aumentaria em 4.000 MW.

O PROINFA também foi um fator importante neste momento, porém os preços oferecidos à energia de biomassa produzida a partir do bagaço de cana não foram interessantes para grande parte dos empresários, que preferiram procurar o mercado atacadista. Assim, o setor que possui um grande potencial de geração de energia, utiliza tecnologias comercialmente disponível e tecnologicamente dominadas, foi aquele que apresentou o menor número de projetos. De acordo com informações da Eletrobrás, foram contratados $685 \mathrm{MW}$ em projetos de biomassa (incluindo biogás, casca de arroz, madeira e bagaço de cana).

Entretanto, ainda existe espaço para o aprimoramento tecnológico de muitas usinas. Um assunto que há bastante tempo é apontado como de grande importância para o setor, principalmente por cientistas e acadêmicos (COELHO, 1992, 1999; WALTER, 1994 entre outros), e que vem agora ganhando força, principalmente em razão do interesse das usinas pelo mercado de energia, e também devido à questões ambientais, é o uso da palha da cana.

A queima da palha de cana é uma técnica utilizada na maioria dos países produtores de canade-açúcar, como forma de facilitar a colheita. O Decreto Federal 2.661 de 09 de julho de 1998 prevê a eliminação gradual da queima da palha da cana, em áreas mecanizáveis, até 2018. No Estado de São Paulo, foi estabelecida legislação que determina a eliminação gradativa da queima de cana, sendo que a eliminação nas áreas mecanizáveis deve ocorrer até 2021 e em áreas não mecanizáveis até o ano de 2031 (HASSUANI; LEAL; MACEDO, 2005). A cana não queimada já atinge 24\% da produção em São Paulo (MACEDO, 2005).

A palha da cana representa de $25 \%$ a $30 \%$ da energia total contida na planta, ou o equivalente a cerca de 10t/ha/ano de matéria seca (BRAUNBECK; CORTEZ, 2005).

Segundo MACEDO (2005), foram feitas estimativas quanto ao aumento dos excedentes de eletricidade para diversos níveis de tecnologias, convencionais ou em desenvolvimento. Os resultados mostram que a operação com sistemas convencionais de alta pressão, utilizando $40 \%$ da palha recuperada, se implantada em $80 \%$ dos sistemas, com a produção atual de cana, poderia gerar cerca de $30 \mathrm{TWh}$ de excedentes. A tecnologia mais promissora, que conduziria a um aumento considerável da produção de energia elétrica é a gaseificação de biomassa integrada à turbina a gás $(\mathrm{BIG} / \mathrm{GT})$. Ainda não existem processos comerciais. A gaseificação 
de biomassa no setor sucroalcooleiro tem sido intensivamente estudada (WALTER, 1994; COELHO, 1992 e outros). 


\section{APLiCAÇão do MOdelo de AVALIAÇÃo de EMPRESAS NO SETOR DE BIOCOMBUSTÍVEIS - BIODIESEL}

Neste capitulo, são apresentadas as características e estudos de viabilidade econômica de empresas do setor de biodiesel. No Capitulo 5 será apresentado o setor de álcool. Além disso, o estudo passa pela formulação de um modelo econômico para aplicação dos modelos de avaliação uma vez que estas empresas convergem para um modelo de mercado - empresas que pertencem a um setor de commodities em formação.

O trabalho aqui desenvolvido baseou-se na avaliação prática de empresas do setor pertencentes aos seguintes segmentos:

- Biodiesel: empresas instaladas na região Centro-Oeste;

- Álcool: empresas instaladas em São Paulo;

Os dados das empresas acima foram coletados, agrupados para transformá-los em premissas de um modelo de negócio para cada segmento. Para este trabalho foi necessária uma pesquisa para identificar as empresas de maior destaque no setor, coletar dados da empresas e informações no negócio, agrupar as informações e elaborar um modelo de negócio para cada segmento.

Os dados são sigilosos, pois todas as empresas envolvidas na pesquisa são de capital fechado. Ainda no Brasil, este setor passa por um processo de profissionalização incluindo abertura de capital. Apenas duas empresas deste setor estão listadas na Bolsa de Valores de São Paulo (BOVESPA), facilitando o acesso às informações do seu negócio:

- Biodiesel: Ecodiesel - abertura em outubro de 2006;

- Álcool: Grupo Cosan - abertura do capital em 2004;

- Carvão Vegetal - não existe nenhuma empresa listada na bolsa.

Com o objetivo de centrar o estudo nos métodos de avaliação e não em características acessórias - como particularidades contábeis e aspectos macroeconômicos - algumas premissas simplificadoras foram adotadas neste trabalho. As mesmas serão citadas neste 
capítulo na medida em que ocorrerem, possibilitando a futuras avaliações um aprofundamento e rigor necessários a este aspectos.

O trabalho aqui desenvolvido baseia-se na avaliação de uma empresa em formação, setor este ainda em expansão que não adquiriu maturidade para formar premissas sólidas na composição dos dados. Desta forma, requer uma avaliação conceitual baseada nos fatos de setores mais próximos, como é o caso do álcool.

\subsection{Apresentação da Empresa}

As informações necessárias para aplicação dos modelos conceituais foram obtidas junto a consultorias responsáveis pelo levantamento de dados de avaliação das empresas existentes.

As informações financeiras foram obtidas de projetos em andamento e estudo de viabilidade de consultoria especializada na montagem de uma usina deste setor localizada na região Centro Oeste. Informações técnicas e comportamento do setor forma baseadas em artigos técnicos e consulta a especialista do setor, incluindo workshop, feiras e congressos. Dados de preços e alíquotas forma levantados com base nos contratos do setor e a ANP (Agencia Nacional do Petróleo). As demais informações forma obtidas junto a órgãos reguladores e fiscalizadores, que serão citados neste trabalho na medida em que as informações obtidas sejam empregadas.

A empresa apresentado no estudo é uma usina em fase de instalação na região Centro-Oeste brasileiro. A capacidade instalada é de 21.600 ton cuja matéria prima é soja.

Como os dados para avaliação foram considerados em uma usina em construção, todos os resultados considerados são projeções a partir de premissas técnicas da engenharia do projeto. Futuras generalizações deste trabalho deverão desprezar aspectos que não se apliquem ao momento do projeto em análise.

O estudo em questão pode ser generalizado tendo em vista apenas algumas premissas variáveis no tempo como é o caso do preço do biodiesel, preço do insumo óleo vegetal, redução do custo de produção com a introdução de novas tecnologias. 


\subsection{Parametrização do Caso Base}

Este caso reflete as principais características do projeto, tendo sido desprezadas peculiaridade não aplicáveis à outras empresas e cuja omissão não representa valores significativos para o fluxo de caixa.

\begin{tabular}{|lc|}
\hline Parâmetros & Valores \\
\hline Capacidade Instalada & 21.600 ton/ano \\
Custo do Investimento & $\mathrm{R} \$ 28.750 \mathrm{mil}$ \\
Custo de Operação & $\$ 0,82 / \mathrm{L}$ \\
Preço do Contrato de Venda & $\mathrm{R} \$ 1,75 / \mathrm{L}$ \\
\hline
\end{tabular}

Tabela 9 - Parâmetros do Caso Base Fonte: Produzida pelo autor

Na tabela o preço de contrato de venda está abaixo do leilão realizado pela ANP (Agência Nacional do Petróleo), os valores de referencia encontram-se na nos patamares de R\$ 1,90/L.

A seguir serão discutidos os parâmetros iniciais da usina de biodiesel, bem como as premissas adotadas para o cálculo do valor da mesma.

\subsubsection{Custo de investimento, Financiamento e Depreciação}

Os investimentos totais para a construção da usina de biodiesel totalizam $\mathrm{R} \$ 28,75$ milhões, dos quais cerca de $40 \%$ foram aportados pelos investidores acionistas e os $60 \%$ restantes captados por terceiros. Apesar dos valores do investimento, este não participa do fluxo de caixa, pois a empresa entrou em operação em janeiro de 2007.

As captações para tal empreendimento contaram com aporte do Banco de Desenvolvimento Econômico e Social - BNDES, todas com base em parâmetros de mercado para negociação. Estes financiamentos, apresentados na tabela abaixo, indicam uma estrutura de capital com uma participação de capital de terceiros da ordem de $60 \%$ do total do empreendimento. 


\begin{tabular}{|lccccc|}
\hline \multicolumn{1}{|c}{ Financiador } & $\begin{array}{c}\text { Valor do } \\
\text { Financiamento }\end{array}$ & Juros & Carência & Prazo & $\begin{array}{c}\text { Premissa de } \\
\text { Refinanciamento }\end{array}$ \\
\hline BNDES & 12.938 & TJLP $+1,25 \%$ a.a. & 20 meses & 10 anos & Refinanciável \\
BNDES & 4.313 & TJLP + 1,50\% a.a. & 10 meses & 5 anos & Refinanciável \\
\hline
\end{tabular}

Tabela 10 - Composição e características dos financiamentos

Fonte: Produzida pelo autor

Considerou-se que o aporte do BNDES será refinanciado em condições e mercado variável que será apresentado nos próximos itens. Esta premissa é conservadora, uma vez que, os pais têm construído bases sólidas para garantir a queda gradual dos juros e um controle maior da inflação. Somado a isso o Brasil vem se aproximando dos patamares de "investment grade". Isso irá favorecer o acesso a capital estrangeiro para o financiamento de projetos no Brasil, como conseqüência do acesso de capital novo entrando no Brasil.

As taxas anuais de depreciação utilizadas no fluxo de caixa seguem as taxas previstas para itens mais relevantes do projeto e calculou-se a média ponderada pela participação destes itens no valor total dos investimentos. A taxa média de depreciação obtida foi de $9,8 \%$ ao ano, ponderada pelo percentual de participação dos ativos correspondentes, conforme apresentado na Tabela 11.

\begin{tabular}{|lrcc|}
\hline \multicolumn{1}{|c}{ Investimentos } & \multicolumn{1}{c}{ Valor } & Participação & Taxa \\
\hline Obras Civis & $2.120 .293,54$ & $10 \%$ & $4,0 \%$ \\
Máquinas/Equipamentos & $17.509 .496,34$ & $81 \%$ & $10,0 \%$ \\
Instalações & $1.028 .434,62$ & $5 \%$ & $10,0 \%$ \\
Veículos & $827.015,09$ & $4 \%$ & $20,0 \%$ \\
Móveis e Utensilios & $77.532,66$ & $0 \%$ & $10,0 \%$ \\
\hline Total & $\mathbf{2 1 . 5 6 2 . 7 7 2 , 2 5}$ & $\mathbf{1 0 0 \%}$ & $\mathbf{9 , 8 \%}$ \\
\hline
\end{tabular}

Tabela 11 - Cálculo da depreciação média.

Fonte: Produzida pelo autor

\subsubsection{Custo de operação da usina de biodiesel}

O custo de produção na produção de biodiesel tem como principais produtos os óleos vegetais oriundos da soja, girassol, mamona, algodão e dendê, destes os mais importantes são a soja e mamona. Para a produção do biodiesel o óleo de mamona e soja tem aplicações em outros setores, portanto o fator de preço do insumo tem aplicações mais nobres, como é o caso do uso de lubrificantes especiais, ração animal e óleo comestível. Como as metas do governo em 
incorporar o biodiesel na matriz energética são agressivas como citadas no Capitulo 3, é esperado pressão de demanda ao longo dos próximos anos, além de manter estimulada a entrada de novos participantes na expansão das culturas oleaginosas acompanhando de uma demanda crescente para estes insumos terá um efeito regulador e previsível, associado a contratos de fornecimentos de tais insumos, que dentro da política de metas do governo irá favorecer o setor.

Em meados de 2005, quando o biodiesel vivia ainda momentos de indefinição no país, uma das empresas líder em montagens industriais no Brasil solicitou um estudo detalhado à universidade para compreender mais profundamente a viabilidade deste biocombustível, seus custos em cada região do país, com diferentes matérias primas e suas reais necessidades logísticas. Um trabalho ambicioso e também fundamental para sustentar a viabilidade econômica deste biocombustível que já passava a ser incluído nos planos da agricultura, da indústria e do setor energético brasileiro. (REVISTA BIODIESEL, 2006).

O estudo foi realizado e os objetivos cumpridos. E hoje serve de referencia para novos projetos Brasil afora, pelo detalhamento que apresenta e pela precisão de informações. Para cada região foi considerado o uso de matérias primas comparáveis com suas respectivas vocações agrícolas. Em cada região, os cálculos foram feitos para plantas industriais de biodiesel de três escalas de produção: 10 mil toneladas por ano, 40 mil ton/ano e $100 \mathrm{mil}$ ton/ano. Independente da escala adota-se para o estudo unidades industriais integradas, ou seja, que realizam a extração do óleo e, também, o processamento do biodiesel.

O local de instalação da indústria foi definido como base, principalmente, na maior disponibilidade de matérias primas agrícolas para geração do óleo. Para tanto, fez-se um exame detalhado dos calendários agrícolas de cinco regiões, bem como das produções médias nas safras de 1999/00 a 2003/04.

O passo seguinte foi o cálculo detalhado dos custos de produção de cada matéria-prima agrícola - custo do produto in natura ao chegar na unidade de extração do óleo. Paralelamente, foram levantados os preços de mercado os mesmos produtos para análise comparativa dos custos finais do biodiesel, quando formados a partir de uma ou outra forma de aquisição - ou seja, se via custo de produção ou preço de mercado.

Posteriormente à análise do segmento agrícola, foram agregados os centros de custos industriais, subdivididos nas etapas de esmagamento e de processamento do biodiesel, 
propriamente dito. Todos os custos e receitas dos "subprodutos", tanto do processo de extração do óleo, quanto de elaboração do biodiesel foram computados na análise.

Em relação à área de matérias primas, a definição dos custos agrícolas envolveu todos os insumos de produção, incluindo o custo de arrendamento da terra e depreciações do maquinário, mas sem considerar assistência técnica ou remunerações do produtor e do capital investido. Esse cálculo foi feito para a soja, girassol, amendoim, mamona e dendê. Para o caroço de algodão, ao invés de custos, consideraram-se os preços do mercado. Esclarece-se que, numa segunda frente de cálculos, todas as matérias primas foram consideradas.

Já para as questões industriais do estudo, foram definidas cinco localidades para a instalação das unidades industriais teóricas. Essa escolha levou em conta a oferta de matéria prima agrícola, o atual mapa das bases de operação das maiores distribuidoras de combustível, os grandes centros de consumo e a distribuição entre si, dessas plantas de biodiesel. Sob esses critérios, as cidades seriam Carazinho (RS), Piracicaba (SP), Rondonópolis (MT), Luiz Eduardo Magalhães (BA) e Marabá (PA).

A análise dos custos de produção do biodiesel deixou clara a grande importância dos subprodutos na contabilidade final da indústria integrada de biodiesel. Na maioria dos casos, o farelo/torta gerado na extração do óleo representa prejuízo à unidade, com a agravante de serem produzidos em grandes quantidades. Já os subprodutos do processo de elaboração do biodiesel são superavitários (glicerina e álcool hidratado), mas gerados em quantidades relativamente pequenas.

A estrutura integrada desde a agricultura até a indústria se mostrou viável no Sudeste para a soja e amendoim, no Centro-Oeste para a soja, no Nordeste apenas para a mamona e no Norte para o dendê, isso se levando em conta os custos de produção da safra 2004/2005.

Isso pode significar um sinal verde para a integração de uma parte tida como estratégica para o abastecimento da indústria do biodiesel. Contudo, há de se pesar que também os custos administrativos de uma estrutura com tamanha verticalização e o montante de capital investido instalações e fluxo de caixa.

A forma de produção que gera o menor valor do biodiesel leva em consideração resultados obtido em plantas de 40mil ton/ano e biodiesel; nos casos dos custos de produção agrícola, 
estes têm incluídos o valor de arrendamento da terra; ao se tratar de valor mínimo de venda, considerou-se a venda do álcool hidratado.

Destaca-se que as alternativas possíveis são as seguintes:

- Matéria prima: duas ou três em cada região (soja, girassol, amendoim, mamona, caroço de algodão e dendê);

- Forma de aquisição da matéria prima: a custo de produção agrícola ou a preço de mercado;

- Composição do valor do biodiesel: custo de produção em si ou a valor mínimo de venda;

Abaixo, segue uma descrição resumida para cada região do Brasil:

\begin{tabular}{|lcccc|}
\hline \multicolumn{1}{|c|}{ Região } & Menor Valor & Fonte & Forma Aquisição MP & Composição do Valor \\
\hline Sul & $\mathrm{R} \$ 0,844 /$ litro & Girassol & Preço Mercado & Custo Produção \\
Sudeste & $\mathrm{R} \$ 0,858 /$ litro & Girassol & Preço Mercado & $\begin{array}{c}\text { Custo Produção ou Valor } \\
\text { Mínimo de Venda }\end{array}$ \\
Centro-Oeste & $\mathrm{R} \$ 0,883 /$ litro & Soja & Custo Produção & Valor Mínimo de Venda \\
Nordeste & $\mathrm{R} \$ 0,712 /$ litro & Algodão & Preço Mercado & Valor Mínimo de Venda \\
Norte & $\mathrm{R} \$ 0,897 /$ litro & Dendê & Custo Produção & Custo de Produção \\
\hline
\end{tabular}

Tabela 12 - Quadro de custo de produção do biodiesel por região.

Fonte: Produzida pelo autor

Um ponto fundamental que determina o custo da matéria prima, melhor especificando os óleos vegetais, é o fato de servir de insumo para outros setores, neste caso: Mercado Farmacêutico, Mercado Químico, Mercado Alimentício e Mercado Energético.

Nestes mercados, a saturação se dá de cima para baixo, ou seja, do mercado farmacêutico em direção do mercado energético, justificando a classificação em forma hierárquica. 
O óleo de mamona, por exemplo, satura o mercado farmacêutico, como fármacos, em algumas dezenas de toneladas, e como matéria prima para a indústria química, incluindo a área cosmética, com menos de $80 \mathrm{mil}$ ton/anuais.

O excedente do mercado químico, por não ser adequado ao mercado alimentício, transborda diretamente para o mercado energético.

Os preços dos excedentes deverão ajustar-se, automaticamente, aos níveis admissíveis e compatíveis e comparáveis para a produção de biodiesel.

\begin{tabular}{|l|c|c|c|}
\hline \multirow{2}{*}{ Mercados } & \multicolumn{3}{|c|}{ Caracteristica de Mercado } \\
\cline { 2 - 4 } & $\begin{array}{c}\text { Grandezas } \\
\text { Relativas }\end{array}$ & $\begin{array}{c}\text { Ordem de } \\
\text { Grandeza } \\
\text { ton/ano }\end{array}$ & $\begin{array}{c}\text { Preços } \\
\text { admissíveis } \\
\text { US\$/ton }\end{array}$ \\
\hline Farmacêutico & muito limitado & $<10^{5}$ & $>2.000$ \\
Químico & moderado & $<10^{6}$ & $700-2.000$ \\
Alimentício & grande & $<10^{7}$ & $450-700$ \\
Energético & limitado & $<10^{7}$ & $<450$ \\
\hline
\end{tabular}

Tabela 13 - Mercados para as oleaginosas.

Fonte: Produzida pelo autor

De acordo com o estudo apresentado no Capítulo 3, o Brasil possui a maior área agrícola disponível para o plantio do planeta, acompanhado de uma expansão da fronteira agrícola. Tem gerado oferta suficiente para atender a demanda de insumo para as novas plantas de biodiesel, portanto esse insumo não vem sofrendo pressões de aumento de preço que poderiam inviabilizar o projeto a nível nacional.

Tratando de uma usina química de capital intensivo, o custo variável é representado pelos insumos. De todos os insumos, o mais relevante é o óleo de soja por ser mais abundante e estar presente nas regiões de destaque para a fabricação do biodiesel, representa $90 \%$ dos custos dos insumos.

O Gráfico 4 apresenta o preço praticado nos últimos anos no preço de soja, principal insumo para a produção do biodiesel. 


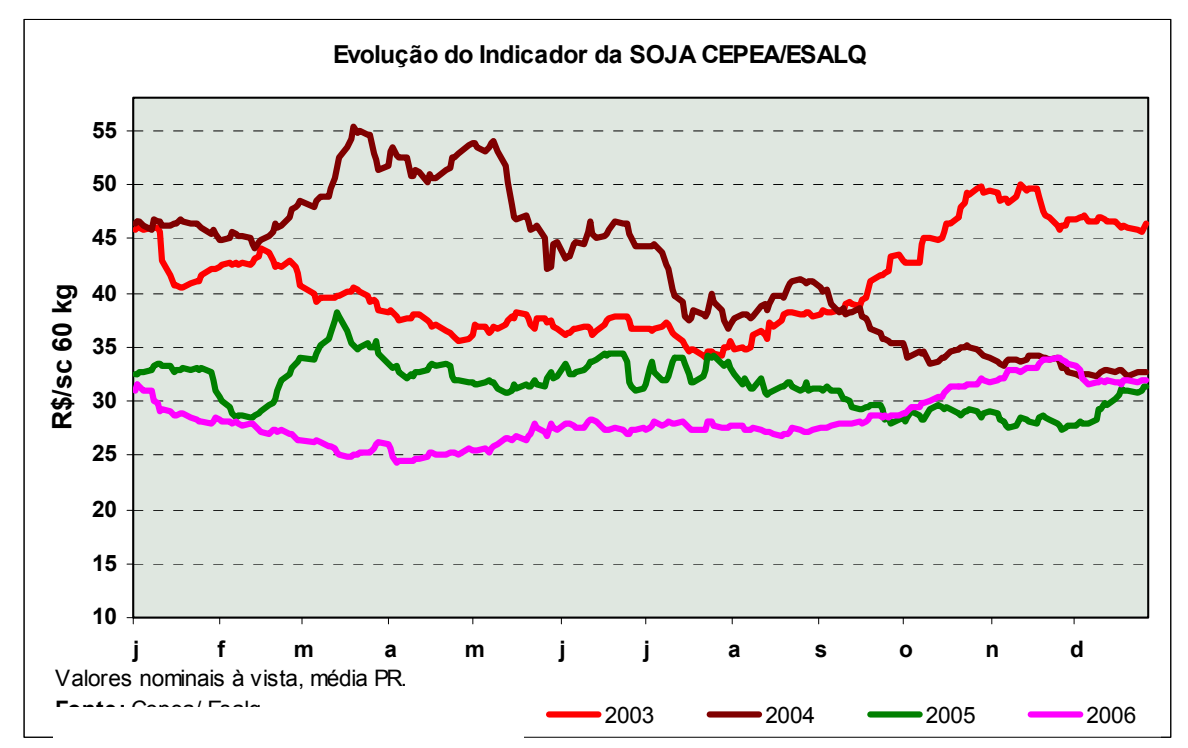

Gráfico 11 - Histórico do preço da soja PR Fonte: CEPEA/ESALQ

O preço tem oscilado em torno de $\mathrm{R} \$ 35,00 / \mathrm{sc} 60 \mathrm{~kg}$ o que equivale a $\mathrm{R} \$ 580,00 /$ ton. O maior valor em 2004 chegando a R\$ 950,00/ton em 2004 e o menor a R\$400,00/ton em 2006.

A tabela abaixo apresenta uma análise de sensibilidade para os formadores do custo do biodiesel. A relevância do custo do óleo de soja e do etanol representa 98\% dos custos dos insumos. Na tabela abaixo a glicerina é um dos subprodutos do processo, entra como receita, diminuindo o custo de fabricação do biodiesel.

\begin{tabular}{|l|}
\hline \multicolumn{1}{|c|}{ Item } \\
\hline Óleo de Soja \\
Etanol \\
NAOH \\
Eletricidade \\
Vapor \\
Glicerina \\
\hline
\end{tabular}

\begin{tabular}{|c|c|c|c|c|c|c|c|}
\hline \multicolumn{3}{|c|}{ Preço [US\$/t ou US\$/(kwh/t)] } & \multirow{2}{*}{$\begin{array}{c}\begin{array}{c}\text { Quant. } \\
\text { (Kg ou Kwh) }\end{array} \\
\text { Médio }\end{array}$} & \multicolumn{3}{|c|}{ Custo [US\$/t ou US\$/(kwh/t)] } & \multirow[b]{2}{*}{ Média (\%) } \\
\hline Min & Max & Médio & & Min & Max & Médio & \\
\hline 270 & 648 & 459 & 965 & 261 & 625 & 443 & $90 \%$ \\
\hline 140 & 350 & 245 & 156 & 22 & 55 & 38 & $8 \%$ \\
\hline 740 & 740 & 740 & 15 & 11 & 11 & 11 & $2 \%$ \\
\hline 50 & 50 & 50 & 35 & 2 & 2 & 2 & $0 \%$ \\
\hline 10 & 10 & 10 & 76 & 1 & 1 & 1 & $0 \%$ \\
\hline 450 & 450 & 450 & 104 & 47 & 47 & 47 & - \\
\hline \multicolumn{4}{|c|}{ Custo Total US\$/ton } & 249 & 647 & 448 & $100 \%$ \\
\hline & & \multicolumn{2}{|c|}{ Custo Total US\$/L } & 0,22 & 0,56 & 0,39 & $100 \%$ \\
\hline & & \multicolumn{2}{|c|}{ Custo Total R\$/L } & 0,47 & 1,21 & 0,84 & $100 \%$ \\
\hline
\end{tabular}

Tabela 14 - Formação do custo de fabricação do biodiesel Fonte: Produzida pelo autor

\subsubsection{Tributos}

Supõe que as alíquotas dos impostos e taxas atualmente praticadas sejam mantidas. A tabela abaixo apresenta as alíquotas de impostos praticados. 


\begin{tabular}{|lc|}
\hline \multicolumn{1}{|c|}{ Tributos } & Aliquota \\
\hline PIS - sobre a receita bruta & $0,65 \%$ \\
COFINS - sobre a receita bruta & $3,00 \%$ \\
Contribuição Social - sobre o lucro antes do IR & $9 \%$ \\
Imposto de Renda - sobre o lucro antes do IR & $25 \%$ \\
ICMS - sobre a receita bruta & Varia p/ Estado \\
\hline
\end{tabular}

Tabela 15 - Tabela de tributos para o biodiesel.

Fonte: Produzida pelo autor

\subsubsection{Preço de Venda}

Para atender o plano do governo em adicionar uma porcentagem de biodiesel no diesel dentro de um cronograma até 2010, foram criados mecanismos de incentivo para a construção de novas usinas. Um desses incentivos são os contratos de longo prazo feitos entre governo e usineiros dentro de leilões realizados periodicamente. Cabe ressaltar que diferente do modelo do Proálcool que no futuro ao lançamento do programa na década de 70 , apareceram distorções de cunho político. Naquele momento o objetivo era a necessidade de substituição do petróleo importado num momento de vulnerabilidade econômica no país, que em pouco mais de uma década deixou de ser problema devido a queda do preço do barril. O cenário marcado pela política atual visa um novo objetivo de redução da poluição nos grandes centros urbanos, desenvolvimento regional e social. Além de colocar o Brasil como fonte de um combustível importante no cenário global.

O preço do diesel vem passando por um período de patamares baixos, frente ao quadro internacional. Os preços praticados pela Petrobrás têm sofrido constantes atuações do governo sendo que, existem pressões para um aumento maior dos preços.

Além disso, este combustível é estratégico para a economia, não deverá receber impactos diretos com o preço internacional do petróleo, devido às seguintes fatores: auto-suficiência e empresa estatal (controle de preços pelo governo). Além disso, tem um forte apelo para a substituição do diesel importado, uma vez que a tendência do consumo de diesel é aumentar mais que a produção nacional. Apenas do esforço recente em trazer a auto-suficiência em petróleo, isso esconde o fato do Brasil importar diesel. 
A projeção dos dados futuros é feita baseada na premissa de não adoção de novas tecnologias para os próximos anos, mesmo assim considerou ganhos de produtividade ao longo do horizonte de projeção. Portando, a receita sofrerá variações de risco apenas na variável preço, já que estimou a venda de toda a capacidade produtiva com aumento de produtividade.

\subsection{Modelagem}

Quanto a aplicação do modelo de avaliação, aplicada a primeira abordagem de análise identificada neste estudo, a de análise qualitativa, identificando quais aspectos dos modelos empregados devem sofrer adaptações especificas para a indústria analisada, constituindo assim uma modelagem própria para esse setor. Neste ponto, foram identificados os value drivers específicos das empresas de biodiesel, através de critérios quantitativos sugeridos pelos autores que abordam tais modelos.

Em um segundo momento, foi aplicado o modelo de fluxo de caixa descontado como ferramenta de avaliação. Além disso, foi apresentado o descritivo de modelos de avaliação de opções e comentados alguns pontos importantes sobre os outros modelos de avaliação. Seguindo a análise, foi realizado um painel comparativo entre os diferentes tamanhos de indústria, focando no caso da soja e mamona, por serem os insumos mais importantes. Dessa forma, foi possível construir uma avaliação por múltiplos de mercado, ou seja, avaliando a capacidade e região geográfica.

O variável foco do trabalho para o cálculo do valor da empresa, pode-se identificada abaixo:

- As informações financeiras relativas à empresa que foram determinantes para a sua avaliação, tratadas neste trabalho como direcionadores do valor ou value drivers. A identificação destes direcionadores de valor foi feita conforme a sugestão da própria bibliografia levantada, identificando impactos financeiros relevantes e testando a sensibilidade dos componentes das taxas de juros praticadas;

- O método de avaliação de empresas e os requisitos para a sua aplicabilidade em casos diversos;

- As informações necessárias para a aplicação com sucesso das duas variáveis anteriores e acessibilidade a estas informações. 
Com base nestas variáveis, desenvolveu-se uma análise qualitativa da aplicação, acessibilidade e utilidade de cada variável, objetivando obter um método ou um conjunto de métodos com diferentes graus de aplicabilidade e precisão. Não coube a este trabalho definir o grau de aplicabilidade dos modelos, mas sim desenvolver subsídios para obtê-lo através da análise qualitativa. Também não foi do escopo desta pesquisa definir um grau específico de precisão nos resultados obtidos para o modelo, mas o mesmo poderá ser estimado em função das limitações impostas pelos modelos mais simples o que foi auferido na análise quantitativa.

\subsubsection{Projeção dos dados da empresa}

A projeção dos resultados da empresa desenvolvida com base nas premissas expostas nos itens 4.2.1 a 4.2.4 é apresentada no Anexo 1. Como a usina é nova com uso das tecnologias desenvolvidas atualmente, previu um levantamento da produtividade baseada nas usinas de açúcar e álcool que nas ultimas décadas passaram por estágios parecidos de desenvolvimento. Além disso, os saltos de produtividade com a introdução de novas tecnologias e aplicações dos subprodutos serão desconsiderados. Portanto o uso da capacidade é de $100 \%$ devido ao momento que o setor se encontra em franca expansão, dentro das metas do governo de adição obrigatória a toda o diesel produzido no Brasil.

O método de avaliação encontra-se em dois estágios:

- Produção crescente linear ao longo dos próximos 10 anos, para isso será estimado um crescimento g, discutido nos itens anteriores. Este ponto será estimado baseado na adoção de melhorias no processo produtivo do biodiesel. O uso do histórico da produção de álcool será um ponto importante para esta análise.

Tabela 2. Indicadores de produtividade da agroindústria canavieira no Brasil, 1975/2000 (*1985/2000)

\begin{tabular}{lr}
\hline Indicador & variação \\
\hline Produtividade agrícola & $+33 \%$ \\
\hline Teor médio de sacarose na cana & $+8 \%$ \\
\hline Eficiência na conversão sacarose a etanol & $+14 \%$ \\
\hline Produtividade na fermentação $\left(\mathrm{m}^{3}\right.$ etanol $\mathrm{m}^{3}$ reator-dia) & $+130 \%$ \\
\hline Conversão agroindustrial média & $+172 \%$ \\
\hline
\end{tabular}

Tabela 16 - Ganhos de produtividade do etanol.

Fonte: Produzida pelo autor 
Como estamos buscando a produtividade na usina, foi desconsiderada a produtividade agrícola e produtividade na fermentação, portanto chegando a um crescimento anual de $1,05 \%$ na capacidade, observando que está sendo considerada apenas eficiência no processo, sem a adoção de novas tecnologias.

O estudo contempla a questão da perpetuidade do negócio após o período de 15 anos (2021) neste caso foi considerado para o cálculo do valor residual a capacidade produção constante do $14^{\circ}$ ano (2020).

No Anexo 1 estão os balanços patrimoniais projetados para a empresa, com base nos resultados obtidos e adotando as seguintes premissas:

- Prazo médio de recebimento das vendas é de 30 dias, com base no ano de 360 dias;

- A estrutura de capital irá se manter com a participação de $60 \%$ de recursos de terceiros e $40 \%$ de recursos próprios;

- Os financiamentos serão renovados de acordo com as suas respectivas amortização;

- A totalidade dos lucros auferidos a cada exercício será distribuída;

- O caixa operacional mantido na empresa será remunerado à taxa de juros de $9 \%$ ao ano;

- O imobilizado será consumido gradativamente logo na fase de inicio de operação pela depreciação projetada;

- A depreciação decresce linearmente à uma taxa média estimada de 9,8\% ao ano;

- A projeção do fluxo de caixa será considerada para os 15 anos de operação da usina, sendo considerada a perpetuidade constante para o cálculo do valor residual.

No Anexo 1 são projetados os fluxos de caixa anuais da empresa, considerando que a empresa distribui aos seus sócios parte do valor integral correspondente ao lucro de cada exercício, em razão da necessidade de investimentos para manutenção dos equipamentos e instalações. 


\subsubsection{Taxa de desconto para ofluxo de caixa livre para o acionista.}

O modelo utilizado para a taxa de desconto apropriada para avaliar o custo de oportunidade do capital empregado para gerar o caixa livre para os acionistas é o CAPM, para isso será necessária a estimativa da taxa livre de risco do mercado, do risco sistemático da empresa (Beta) e do prêmio médio esperado para o mercado brasileiro.

A taxa livre de risco para o mercado brasileiro é estimada considerando a taxa de juros americana e estimando alguns cenários possíveis. Além disso, foram considerados 2 momentos para o desconto, sendo que a taxa 1 refere-se ao momento atual e a taxa 2 daqui a 3 anos (adotando um viés conservador).A principal agencia de risco S\&P acredita que mantendo a conjuntura atual o Brasil, o país entrará no grau de investimento, ou seja, país com graus de risco baixo em condições de receber investimentos dos grandes fundos internacionais.

\begin{tabular}{|l|}
\hline \multicolumn{1}{|c|}{ Item } \\
\hline Risco País (bp) \\
Juros Títulos Brasileiros Exterior \\
Juros Americanos \\
Selic \\
IPCA \\
Juros Reais \\
\hline
\end{tabular}

\begin{tabular}{|c|c|}
\hline Taxa 1 & Taxa 2 \\
\hline 150 & 90 \\
$8,50 \%$ & $7,90 \%$ \\
$4,85 \%$ & $4,85 \%$ \\
$12,00 \%$ & $10,00 \%$ \\
$2,50 \%$ & $2,50 \%$ \\
$9,27 \%$ & $7,32 \%$ \\
\hline
\end{tabular}

Tabela 17 - Tabela de juros.

Fonte: Produzida pelo autor

Quanto a um eventual cenário inflacionário, não há necessidade de computar-se a título de previsão, a taxa de inflação, uma vez que os valores são projetados em moeda constante. Isto se explica facilmente, pois o valor atual, por definição, é dado pelo valor da moeda no momento em que o investimento é realizado. Os fluxos de caixa livre também são apurados no instante de sua formação. Se atualizarmos esses fluxos com uma taxa de inflação projeta, teremos que descontar desses fluxos às mesmas taxas, para obter seu valor presente. Assim, este método permite ignorar a inflação, já que a análise é feita em moeda constante. Portanto, não haveria qualquer modificação no cálculo do valor presente caso inflacionássemos os valores antes e os deflacionássemos depois. 


\subsubsection{Cálculo do beta}

A falta de empresas deste setor em especial no Brasil, onde é o foco de estudo, forçará a busca de outras empresas em setores similares. Neste caso, o setor mais próximo que também faz parte dos bicombustíveis é o álcool. Pela falta, de empresas de biodiesel de capital aberto no exterior, não foi possível buscar recurso para este fim.

O beta foi calculado buscando empresas no exterior no setor de etanol, sendo consideradas as premissas de perfil semelhantes e compatibilidade de risco de negócios e alavancagem financeira. $\mathrm{O}$ beta médio do setor foi adotado como beta previsto para a empresa avaliada.

Através de pesquisa ao sistema Bloomberg (2007), foi feito um levantamento das informações de mercado do setor de álcool, utilizando como parâmetros: a data referência em dezembro de 2006, prazo histórico para a análise estatística de 24 meses, dados em moedas locais de cada país. Os detalhes estão no Anexo 1.

\section{Beta
Beta $\quad$ Desalavancado}

\begin{tabular}{lcc}
\hline Média & 0,78 & 0,56 \\
\hline Mediana & 0,78 & 0,56 \\
\hline Desvio Padrão & $\mathbf{0 , 2 4}$ & $\mathbf{0 , 2 1}$ \\
\hline
\end{tabular}

Tabela 18 - Cálculo do Beta.

Fonte: Produzida pelo autor

A média dos valores calculados indica um Beta de 0,56, que foi o valor adotado como referencia do risco sistemático para o cálculo do custo de capital próprio da empresa analisada, apresentado no próximo item.

\subsubsection{Aplicação do CAPM}

A análise dos resultados obtidos mostra um beta médio de 0,56 para as empresas brasileiras do setor de biocombustíveis. A partir do beta estimado, foram reunidos os elementos necessários à aplicação do Capital Asset Pricing Model - CAPM para determinar o custo de capital próprio. Portanto, fez-se necessário definir os parâmetros componentes do modelo, a saber: 
a) Taxa livre e risco do mercado brasileiro: adotou-se para a taxa de risco a Taxa de Juros em 2 momentos distintos como discutido num dos itens acima neste capítulo. Para o momento 1 (primeiros 3 anos) a taxa de 12,50\% e no momento 2 (após os primeiros 3 anos) a taxa de $10,00 \%$.

b) Taxa de retorno do mercado brasileiro: adotou-se a taxa de retorno do Índice Bovespa para uma série de 10 anos capitalizada pelo método contínuo. A seleção deste intervalo deve-se ao fato de o mesmo representar o único período da história recente do Brasil em que a economia pós Plano Real desenvolveu de forma globalizada. Nos últimos 5 anos, houve crescimento significativo no mercado acionário brasileiro com a entrada de novas empresas na bolsa, aumento do número de investidores e mudança de foco quanto ao nível de especulação. Este período pode ser dividido em 2 etapas:

a. Fase 1 - Momento de expansão especulativo: parte dos recursos investidos em bolsa apresentava riscos maiores que os atuais pelo simples fato do país entrar em períodos de turbulências e vulnerabilidade e maior participação de grandes players.

b. Fase 2 - Momento de expansão na forma de investimento: a entrada do grande público no mercado acionário brasileiro, apresentando momentos do crescimento de abertura do capital de novas empresas, associado ao fato do Brasil alcançar recentemente maior estabilidade econômica.

Prêmio de risco nos mercados acionários: conforme DAMODARAN (1997) há três fundamentos que determinam o prêmio pelo risco nos mercados acionários dos diferentes países: instabilidade econômica, risco político e estrutura de mercado. O premio pelo risco é calculado pela diferença do retorno médio de mercado e a taxa livre de risco adotada.

\begin{tabular}{|l|c|c|c|}
\hline \multicolumn{1}{|c|}{ Componente } & Taxa 1 & Taxa 2 & Descrição \\
\hline $\begin{array}{l}\text { Taxa livre de Risco } \\
\text { Brasileira }\left(r_{\mathrm{f}}\right)\end{array}$ & $12,50 \%$ & $10,00 \%$ & Taxa Juros Projetada \\
\hline $\begin{array}{l}\text { Retorno do Mercado } \\
\text { Brasileiro }\left(r_{\mathrm{m}}\right)\end{array}$ & $10,25 \%$ & $10,25 \%$ & $\begin{array}{c}\text { Retorno médio anual do índice } \\
\text { BOVESPA de 1996-2006 }\end{array}$ \\
\hline $\begin{array}{l}\text { Prêmio pelo Risco de } \\
\text { Mercado }\end{array}$ & $-2,25 \%$ & $0,25 \%$ & $\begin{array}{c}\text { Prêmio pelo risco (spread) entre o } \\
\text { retorno livre de risco e o retorno de } \\
\text { mercado }\end{array}$ \\
\hline
\end{tabular}

Tabela 19 - Aplicação do CAPM - Taxas ao ano 
Na tabela acima o prêmio de risco é inferior à desejada pelos investidores, que de acordo com COOPERS \& LYBRAND apud CASTRO (2000) deve ser de 4\%. Neste caso, como o mercado está em fase de maturação quando comparado ao passado optou-se em trabalhar como o prêmio de risco de 4\%. Portanto, o retorno médio esperado para o mercado e a taxa livre de risco mais a estimativa de premio de risco de $4 \%$, resultando em um retorno médio esperado de mercado de $14,74 \%$ no instante 1 e $12,24 \%$ no instante 2 .

Partindo destas premissas adotadas, podemos determinar o custo de capital próprio para as empresas do setor de biocombustíveis aplicando a Equação:

$$
K_{e}=r_{f}+\beta\left(E\left[r_{m}\right]-r_{f}\right)
$$

Que nos fornece o seguinte resultado:

$$
\begin{aligned}
& \mathrm{K}_{\mathrm{e}, 1}=14,74 \% \text { ao ano no período } 1 ; \\
& \mathrm{K}_{\mathrm{e}, 2}=12,24 \% \text { ao ano no período } 2 .
\end{aligned}
$$

\subsubsection{Cálculo do Custo Médio Ponderado de Capital - WACC}

Conforme exposto no Capítulo 2, alternativamente à valoração da empresa pelo desconto do fluxo de caixa para o acionista, pode-se atingir o mesmo objetivo descontando o fluxo de caixa para a empresa com uma taxa de desconto diferenciada, obtida pelo custo médio ponderado de capital - WACC. Esta nova taxa deve refletir a remuneração esperada pelo capital total empregado na empresa, incluindo o capital de terceiros (representado pelo passivo da empresa). A suposição feita em relação à estrutura da dívida da empresa foi a de que todo o capital de terceiro da empresa seria refinanciado a uma taxa igual àquela praticada no financiamento original. Ao se optar pela análise dos fluxos de caixa para a empresa, a taxa de desconto utilizada foi o WACC e, neste caso, mudanças na composição da divida com diferentes taxas de juros resultaram em um WACC variável, exigindo que os fluxos de caixa fossem descontados a taxas diferentes a cada período. O conceito de WACC variável aplicase aos primeiros anos de atividade da usina, pois foram adotadas diferentes taxas ao longo da vida da empresa. 
Conforme proposto no Capítulo 2, defini-se o WACC como o custo ponderado entre o custo de capital próprio e custo de capital de terceiros. Para o custo de capital de terceiros, adotouse as taxas de juros dos financiamentos realizados com o BNDES, livres de inflação, e descontou-se das mesmas o imposto de renda e a contribuição social ( $9 \%$ no total). Assim, foi obtida a estrutura de taxas de juros mostrada na tabela.

\begin{tabular}{|l|c|c|c|}
\hline \multicolumn{1}{|c|}{ Componente } & Taxa 1 & Taxa 2 & Descrição \\
\hline $\begin{array}{l}\text { Taxa do financiamento } \\
\text { TJLP }\end{array}$ & $7,50 \%$ & $5,92 \%$ & Taxa Juros Projetada \\
\hline Spread Bancário Médio & $1,25 \%$ & $1,00 \%$ & Taxa cobrada pelo banco para repasse \\
\hline Taxa de Financiamento & $8,75 \%$ & $6,92 \%$ & Taxa efetiva de Financiamento \\
\hline
\end{tabular}

Tabela 20 - Taxa de Financiamento.

Fonte: Produzida pelo autor

Partindo destas premissas adotadas, podemos determinar o custo de capital próprio para as empresas do setor de biodiesel aplicando a Equação:

$$
K_{d}=i^{*}(1-I R)
$$

Que nos fornece o seguinte resultado:

$$
\begin{aligned}
& \mathrm{K}_{\mathrm{d}, 1}=6,74 \% \text { ao ano no período } 1 ; \\
& \mathrm{K}_{\mathrm{d}, 2}=5,33 \% \text { ao ano no período } 2 .
\end{aligned}
$$

Aplicando a formulação para o cálculo do WACC de acordo com a equação descrita no Capítulo 2, temos a estrutura temporal da taxa de desconto apresentada na tabela. 


\begin{tabular}{|c|c|c|c|c|c|c|c|}
\hline & 2007 & 2008 & 2009 & 2010 & 2011 & 2012 & 2013 \\
\hline Estrutura Capital & $100 \%$ & $100 \%$ & $100 \%$ & $100 \%$ & $100 \%$ & $100 \%$ & $100 \%$ \\
\hline Própria & $40 \%$ & $58 \%$ & $68 \%$ & $74 \%$ & $79 \%$ & $82 \%$ & $85 \%$ \\
\hline Terceiros & $60 \%$ & $42 \%$ & $32 \%$ & $26 \%$ & $21 \%$ & $18 \%$ & $15 \%$ \\
\hline \multicolumn{8}{|l|}{ Custo do Capital Próprio } \\
\hline Taxa Livre de Risco & $12,50 \%$ & $11,67 \%$ & $10,83 \%$ & $10,00 \%$ & $10,00 \%$ & $10,00 \%$ & $10,00 \%$ \\
\hline Risco de Mercado & $4,00 \%$ & $4,00 \%$ & $4,00 \%$ & $4,00 \%$ & $4,00 \%$ & $4,00 \%$ & $4,00 \%$ \\
\hline Beta & 0,56 & 0,56 & 0,56 & 0,56 & 0,56 & 0,56 & 0,56 \\
\hline Ke & $14,74 \%$ & $13,91 \%$ & $13,07 \%$ & $12,24 \%$ & $12,24 \%$ & $12,24 \%$ & $12,24 \%$ \\
\hline \multicolumn{8}{|c|}{ Custo do Capital de Terceiros } \\
\hline TJLP & $7,50 \%$ & $7,00 \%$ & $6,50 \%$ & $6,00 \%$ & $6,00 \%$ & $6,00 \%$ & $6,00 \%$ \\
\hline Spread bancário & $1,25 \%$ & $1,17 \%$ & $1,08 \%$ & $1,00 \%$ & $1,00 \%$ & $1,00 \%$ & $1,00 \%$ \\
\hline IR+ Contribuição Social & $22,00 \%$ & $22,00 \%$ & $22,00 \%$ & $22,00 \%$ & $22,00 \%$ & $22,00 \%$ & $22,00 \%$ \\
\hline Kd & $6,83 \%$ & $6,37 \%$ & $5,92 \%$ & $5,46 \%$ & $5,46 \%$ & $5,46 \%$ & $5,46 \%$ \\
\hline \multirow[t]{2}{*}{ WACC } & $9,99 \%$ & $10,73 \%$ & $10,77 \%$ & $10,50 \%$ & $10,80 \%$ & $11,02 \%$ & $11,19 \%$ \\
\hline & 2014 & 2015 & 2016 & 2017 & 2018 & 2019 & 2020 \\
\hline Estrutura Capital & $100 \%$ & $100 \%$ & $100 \%$ & $100 \%$ & $100 \%$ & $100 \%$ & $100 \%$ \\
\hline Própria & $86 \%$ & $88 \%$ & $89 \%$ & $90 \%$ & $91 \%$ & $92 \%$ & $93 \%$ \\
\hline Terceiros & $14 \%$ & $12 \%$ & $11 \%$ & $10 \%$ & $9 \%$ & $8 \%$ & $7 \%$ \\
\hline \multicolumn{8}{|l|}{ Custo do Capital Próprio } \\
\hline Taxa Livre de Risco & $10,00 \%$ & $10,00 \%$ & $10,00 \%$ & $10,00 \%$ & $10,00 \%$ & $10,00 \%$ & $10,00 \%$ \\
\hline Risco de Mercado & $4,00 \%$ & $4,00 \%$ & $4,00 \%$ & $4,00 \%$ & $4,00 \%$ & $4,00 \%$ & $4,00 \%$ \\
\hline Beta & 0,56 & 0,56 & 0,56 & 0,56 & 0,56 & 0,56 & 0,56 \\
\hline $\mathrm{Ke}$ & $12,24 \%$ & $12,24 \%$ & $12,24 \%$ & $12,24 \%$ & $12,24 \%$ & $12,24 \%$ & $12,24 \%$ \\
\hline \multicolumn{8}{|c|}{ Custo do Capital de Terceiros } \\
\hline TJLP & $6,00 \%$ & $6,00 \%$ & $6,00 \%$ & $6,00 \%$ & $6,00 \%$ & $6,00 \%$ & $6,00 \%$ \\
\hline Spread bancário & $1,00 \%$ & $1,00 \%$ & $1,00 \%$ & $1,00 \%$ & $1,00 \%$ & $1,00 \%$ & $1,00 \%$ \\
\hline IR+ Contribuição Social & $22,00 \%$ & $22,00 \%$ & $22,00 \%$ & $22,00 \%$ & $22,00 \%$ & $22,00 \%$ & $22,00 \%$ \\
\hline Kd & $5,46 \%$ & $5,46 \%$ & $5,46 \%$ & $5,46 \%$ & $5,46 \%$ & $5,46 \%$ & $5,46 \%$ \\
\hline WACC & $11,32 \%$ & $11,43 \%$ & $11,52 \%$ & $11,59 \%$ & $11,65 \%$ & $11,70 \%$ & $11,75 \%$ \\
\hline
\end{tabular}

Tabela 21 - Cálculo do WACC.

Fonte: Produzida pelo autor

O WACC para o ano 2007 deve ser considerado integral, pois o estudo parte do princípio que o valor da empresa será calculado com base no fechamento do balanço em dezembro de 2006, desta data em diante os dados serão projeções baseadas nos resultados e modelo de negócio. A estrutura temporal de WACCs variáveis apresentada na tabela foi então utilizada para desconto dos fluxos de caixa para a empresa, para obtenção de uma estimativa de valor para a empresa. 


\subsection{Aplicação do método de avaliação ao caso base}

Conforme as premissas e parametrizações identificadas no inicio deste capítulo, procedeu-se à projeção dos resultados, balanços patrimoniais e fluxos de caixa para o acionista. Estas projeções encontram-se no Anexo 1. Toda a estimativa de valor da empresa foi baseada em seus fluxos de caixa e no valor residual.

\subsubsection{Fluxo de caixa para o acionista}

O fluxo de caixa apresentado nos Anexo 1 corresponde ao fluxo de caixa líquido para os acionistas. Todo o fluxo de caixa foi descontado à uma taxa variável pelo CAPM apresentados no item 4.3.2.2. O valor presente do fluxo acumulado e a evolução dos mesmos são apresentados na tabela. Lembrando que a partir de 2020, o valor da empresa é baseado na perpetuidade com crescimento de fluxo zero.

\begin{tabular}{|c|c|c|c|}
\hline & \multicolumn{2}{|c|}{ Taxa Calculada } \\
\hline Ano & \begin{tabular}{|c|}
$\begin{array}{c}\text { Fluxo de Caixa } \\
\mathrm{R} \$ \mathrm{mil}\end{array}$ \\
\end{tabular} & $\mathrm{Ke}$ & $\begin{array}{c}\text { VP Fluxo Caixa } \\
\text { R\$ mil }\end{array}$ \\
\hline 2007 & 12.143 & $14,74 \%$ & 10.583 \\
\hline 2008 & 12.756 & $13,91 \%$ & 20.415 \\
\hline 2009 & 13.334 & $13,07 \%$ & 29.638 \\
\hline 2010 & 14.117 & $12,24 \%$ & 38.533 \\
\hline 2011 & 14.738 & $12,24 \%$ & 46.807 \\
\hline 2012 & 15.376 & $12,24 \%$ & 54.497 \\
\hline 2013 & 16.033 & $12,24 \%$ & 61.642 \\
\hline 2014 & 16.709 & $12,24 \%$ & 68.276 \\
\hline 2015 & 17.404 & $12,24 \%$ & 74.432 \\
\hline 2016 & 18.118 & $12,24 \%$ & 80.142 \\
\hline 2017 & 18.853 & $12,24 \%$ & 85.436 \\
\hline 2018 & 19.623 & $12,24 \%$ & 90.345 \\
\hline 2019 & 20.416 & $12,24 \%$ & 94.895 \\
\hline 2020 & 21.230 & $12,24 \%$ & 99.111 \\
\hline \multirow[t]{2}{*}{$>2020$} & 22.067 & $12,24 \%$ & 133.366 \\
\hline & & & $\mathrm{R} \$ \mathrm{mil}$ \\
\hline \multirow{2}{*}{\multicolumn{3}{|c|}{$\begin{array}{l}\text { Total Fluxo Caixa Projetado } \\
\text { Total Resíduo Projetado }\end{array}$}} & 99.111 \\
\hline & & & 34.255 \\
\hline \multicolumn{3}{|c|}{ Total Valor para Acionista } & 133.366 \\
\hline & & & $(\%)$ \\
\hline \multirow{2}{*}{\multicolumn{3}{|c|}{$\begin{array}{l}\text { Total Fluxo Caixa Projetado } \\
\text { Total Resíduo Projetado }\end{array}$}} & $74,3 \%$ \\
\hline & & & $25,7 \%$ \\
\hline \multicolumn{3}{|c|}{ Total Valor para Acionista } & $\overline{100,0 \%}$ \\
\hline
\end{tabular}


Tabela 22 - Valor presente do fluxo de caixa para acionista.

Fonte: Produzida pelo autor

Observa-se que o horizonte proposto para o cálculo do fluxo de caixa, permitiu gerar resultados satisfatórios na relação do valor total dos fluxos de caixa projetados e o valor total para o acionista $(74,0 \%)$. Para o acionista considerando todas as premissas propostas, chegase ao valor de $\mathrm{R} \$ 133.366$ mil.

\subsubsection{Fluxo de caixa para a empresa}

Procedeu-se aos ajustes necessários ao fluxo de caixa para obter os fluxos de caixa para a empresa, os quais foram descontados a valor presente pela estrutura temporal dos WACCs apresentada na Tabela. Para tanto, desenvolveu-se a projeção da taxa de desconto para desconto de cada fluxo de caixa. As projeções da taxa de desconto acumulada, dos ajustes para compor os fluxos de caixa para a empresa do valor presente de cada fluxo e do valor presente total acumulado do fluxo de caixa são apresentados na tabela. 


\begin{tabular}{|c|c|c|c|}
\hline & \multicolumn{2}{|c|}{ Taxa Calculada } \\
\hline Ano & \begin{tabular}{|c|}
$\begin{array}{c}\text { Fluxo de Caixa } \\
\mathrm{R} \$ \mathrm{mil}\end{array}$ \\
\end{tabular} & WACC & $\begin{array}{l}\text { VP Fluxo Caixa } \\
\text { R\$ mil }\end{array}$ \\
\hline 2007 & 13.074 & $9,99 \%$ & 11.886 \\
\hline 2008 & 13.688 & $10,73 \%$ & 23.050 \\
\hline 2009 & 14.265 & $10,77 \%$ & 33.545 \\
\hline 2010 & 15.048 & $10,50 \%$ & 43.640 \\
\hline 2011 & 15.669 & $10,80 \%$ & 53.023 \\
\hline 2012 & 16.307 & $11,02 \%$ & 61.731 \\
\hline 2013 & 16.964 & $11,19 \%$ & 69.805 \\
\hline 2014 & 17.640 & $11,32 \%$ & 77.284 \\
\hline 2015 & 18.335 & $11,43 \%$ & 84.207 \\
\hline 2016 & 19.049 & $11,52 \%$ & 90.612 \\
\hline 2017 & 18.853 & $11,59 \%$ & 96.256 \\
\hline 2018 & 19.623 & $11,65 \%$ & 101.485 \\
\hline 2019 & 20.416 & $11,70 \%$ & 106.327 \\
\hline 2020 & 21.230 & $11,75 \%$ & 110.809 \\
\hline \multirow[t]{2}{*}{$>2020$} & 22.067 & $11,75 \%$ & 153.624 \\
\hline & & & $\mathrm{R} \$ \mathrm{mil}$ \\
\hline \multirow{2}{*}{\multicolumn{3}{|c|}{$\begin{array}{l}\text { Total Fluxo Caixa Projetado } \\
\text { Total Resíduo Projetado }\end{array}$}} & 110.809 \\
\hline & & & 42.814 \\
\hline \multicolumn{3}{|c|}{ Total Valor Empresa } & 153.624 \\
\hline & & & $(\%)$ \\
\hline \multirow{2}{*}{\multicolumn{3}{|c|}{$\begin{array}{l}\text { Total Fluxo Caixa Projetado } \\
\text { Total Resíduo Projetado }\end{array}$}} & $72,1 \%$ \\
\hline & & & $27,9 \%$ \\
\hline \multicolumn{3}{|c|}{ Total Valor Empresa } & $100,0 \%$ \\
\hline
\end{tabular}

Tabela 23 - Valore presente do fluxo de caixa para empresa Fonte: Produzida pelo autor

Na tabela abaixo o fluxo de caixa projetado comparado com o fluxo de caixa total chegou a uma relação satisfatória de $72,1 \%$. Para o cálculo do valor do acionista baseado no valor da empresa, subtraímos alguns componentes do valor da empresa, como segue na tabela.

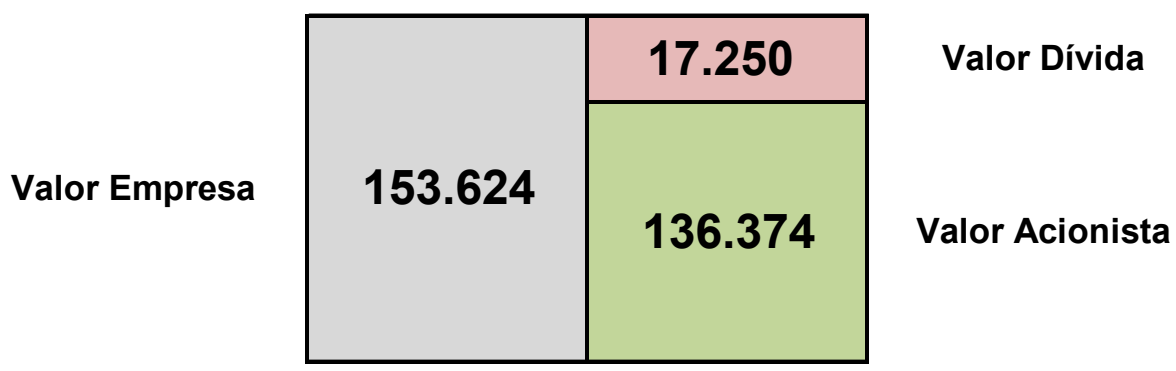

Tabela 24 - Diagrama de composição de valores (em R \$ mil) Fonte: Produzida pelo autor 
Comparando os valores dos acionistas pelos métodos descritos nos itens 4.4.1 e 4.4.2, verificamos uma diferença de $2,25 \%$, ou seja,

\subsubsection{Sensibilidade sobre a Taxa de Desconto}

A taxa de desconto é utilizada para descontar os fluxos de caixa futuro da empresa e também indica retorno esperado pelo investidor. No Capítulo 2 ficou evidente a dificuldade em se calcular com precisão o custo de capital próprio de uma empresa brasileira, dada a escassez de informações e a rentabilidade atípica das empresas listadas em bolsa de valores durante a década de 90. Em razão desta dificuldade, torna-se bastante útil uma análise da sensibilidade do valor obtido para a empresa faze a variação na taxa de desconto.

Como o custo de capital de terceiros - o custo dos juros das dívidas - é perfeitamente identificado em relações contratuais, o único componente que pode gerar incerteza na composição do custo de capital é o custo de capital próprio. Assim, precedeu-se a uma análise dos valores que seria obtido para diferentes possibilidades de custo de capital próprio, estimadas em variações iguais à mais ou menos 2 pontos percentuais, todas elas acima do mais algo custo da dívida.

A tabela apresenta as estimativas de valores finais obtidos para a empresa, segundo cada um dos métodos empregados. 


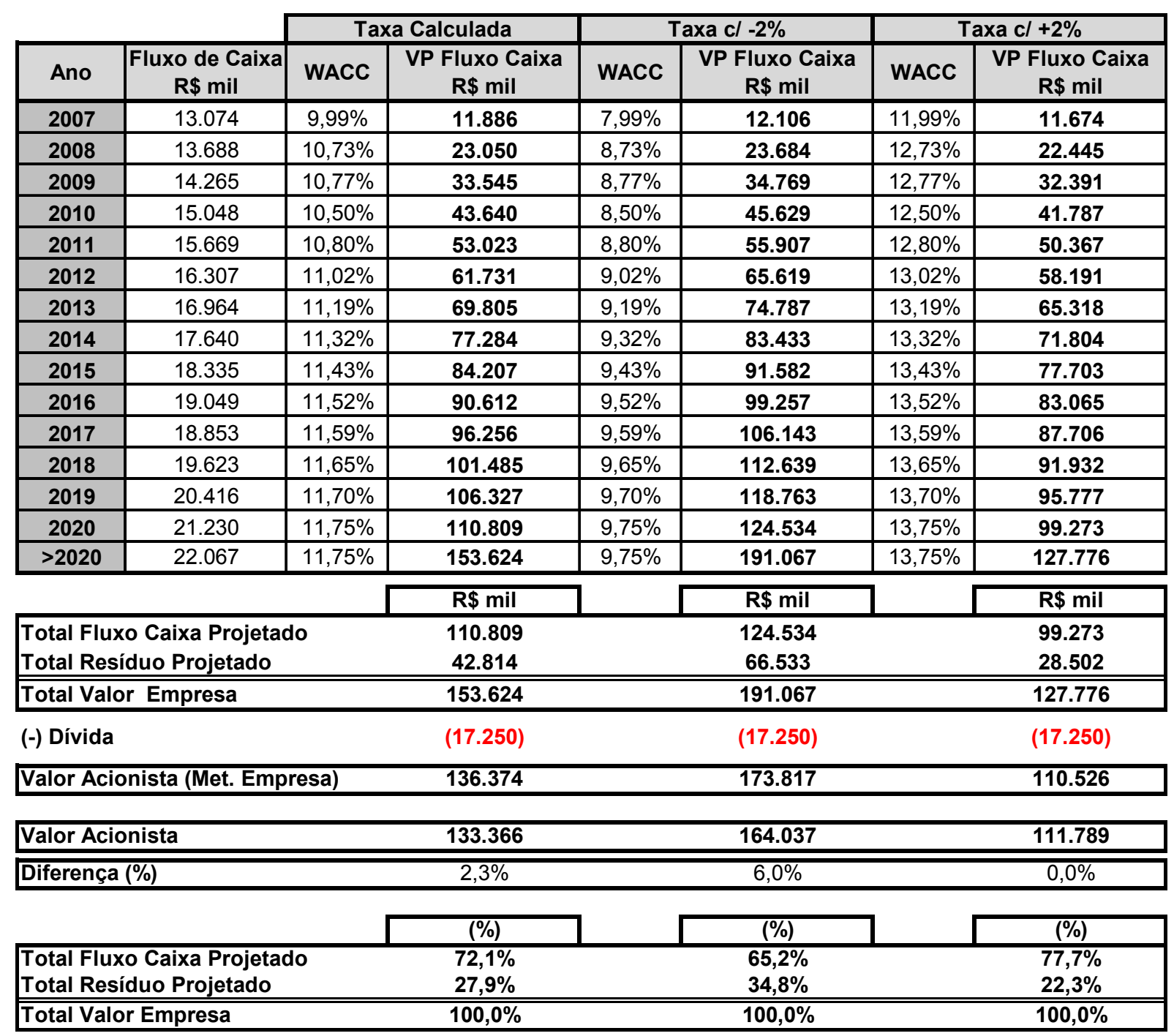

Tabela 25 - Resultado do Valor da Empresa

Fonte: Produzida pelo autor

O emprego do método do Valor Presente dos Fluxos de Caixa Projetados mostrou-se satisfatório como ferramenta de valoração da empresa em razão da diversidade de parâmetros considerados e do pleno cumprimento das limitações observadas nos métodos descritos no Capítulo 2. Simplificações no timing de caixa da empresa, embutidas nas projeções dos fluxos de caixa, levaram a diferenças nas estimativas de valor obtidas a partir dos fluxos de caixa para a empresa e para o acionista.

O modelo de fluxos de caixa pode ser tratado como variáveis aleatórias, mas não iremos encontrar diferença entre a valoração média deste método e o valor determinístico da forma simplificada. A razão para isso é a significativa previsibilidade do fluxo de caixa para este tipo de empresa, limitando a componentes pouco significativos do caixa a incerteza para a variabilidade no fluxo. Observa-se, portanto, que o emprego da técnica de projeção supondo o 
fluxo de caixa como variável aleatória apenas tem a contribuir com a percepção da variabilidade dos possíveis valores. A limitação deste método está na dificuldade em se desenvolver um modelo consistente para a estimativa do custo de capital próprio da empresa, dada a ineficiência das ações das empresas do setor no mercado de capitais.

\subsubsection{Múltiplos setoriais}

O objetivo deste item do trabalho é simular o valor da empresa nas diferentes regiões do Brasil e com diferentes fontes de matéria prima, incluindo: soja, dendê, algodão e girassol.

Na tabela encontram-se o resultado do último leilão da ANP para os preços de biodiesel nas principais regiões, estados e empresas.

\begin{tabular}{|c|c|c|c|c|c|}
\hline Regiāo & $\begin{array}{c}\text { Volume } \\
\text { arrematado }\left(\mathbf{m}^{3}\right)\end{array}$ & $\%$ & Valor (R\$) & $\%$ & $\begin{array}{l}\text { Preço Médio } \\
\left(\mathrm{R} \$ / \mathrm{m}^{3}\right)\end{array}$ \\
\hline Sul & 160.000 & $29,1 \%$ & $281.864 .800,00$ & $29,3 \%$ & $1.761,66$ \\
\hline Sudeste & 2.651 & $0,5 \%$ & $4.745 .926,24$ & $0,5 \%$ & $1.790,24$ \\
\hline Centro Oeste & 79.129 & $14,4 \%$ & $140.832 .833,24$ & $14,7 \%$ & $1.779,79$ \\
\hline Nordeste & 218.220 & $39,7 \%$ & $377.520 .600,00$ & $39,3 \%$ & $1.730,00$ \\
\hline Norte & 90.000 & $16,4 \%$ & $155.700 .000,00$ & $16,2 \%$ & $1.730,00$ \\
\hline Total & 550.000 & $100,0 \%$ & $960.664 .159,48$ & $100,0 \%$ & $1.746,66$ \\
\hline
\end{tabular}

PARTICIPAC̣̃̃O POR ESTADO

\begin{tabular}{|c|r|r|r|r|r|}
\hline UF & $\begin{array}{r}\text { Volume } \\
\text { arrematado }\left(\mathbf{m}^{\mathbf{3}}\right)\end{array}$ & \multicolumn{1}{|c|}{$\%$} & \multicolumn{1}{c|}{ Valor $(\mathbf{R} \$ \mathbf{)}$} & $\begin{array}{c}\text { Preço Médio } \\
\left(\mathbf{R} \mathbf{\$} / \mathbf{m}^{3}\right)\end{array}$ \\
\hline BA & 80.000 & $14,5 \%$ & $138.400 .000,00$ & $14,4 \%$ & $1.730,00$ \\
\hline CE & 88.220 & $16,0 \%$ & $152.620 .600,00$ & $15,9 \%$ & $1.730,00$ \\
\hline GO & 30.000 & $5,5 \%$ & $53.678 .700,00$ & $5,6 \%$ & $1.789,29$ \\
\hline MA & 50.000 & $9,1 \%$ & $86.500 .000,00$ & $9,0 \%$ & $1.730,00$ \\
\hline MG & 2.651 & $0,5 \%$ & $4.745 .926,24$ & $0,5 \%$ & $1.790,24$ \\
\hline MT & 49.129 & $8,9 \%$ & $87.154 .133,24$ & $9,1 \%$ & $1.773,99$ \\
\hline RS & 160.000 & $29,1 \%$ & $281.864 .800,00$ & $29,3 \%$ & $1.761,66$ \\
\hline TO & 90.000 & $16,4 \%$ & $155.700 .000,00$ & $16,2 \%$ & $1.730,00$ \\
\hline Total & 550.000 & $100,0 \%$ & $960.664 .159,48$ & $100,0 \%$ & $1.746,66$ \\
\hline
\end{tabular}

\section{PARTICIPACÃO POR EMPRESA}

\begin{tabular}{|c|c|c|c|c|c|}
\hline Empresa & $\begin{array}{c}\text { Volume } \\
\text { arrematado }\left(\mathrm{m}^{3}\right)\end{array}$ & $\%$ & Valor $(R \$)$ & $\%$ & $\begin{array}{l}\text { Preço Médio } \\
\left(\mathrm{R} \$ / \mathrm{m}^{3}\right)\end{array}$ \\
\hline Agrosoja & 5.000 & $0,9 \%$ & 8.570 .000 & $0,9 \%$ & $1.714,00$ \\
\hline Barrálcool & 16.629 & $3,0 \%$ & 29.602 .483 & $3,1 \%$ & $1.780,17$ \\
\hline Biominas & 2.651 & $0,5 \%$ & 4.745 .926 & $0,5 \%$ & $1.790,24$ \\
\hline Brasil Biodiesel & 388.220 & $70,6 \%$ & 671.620 .600 & $69,9 \%$ & $1.730,00$ \\
\hline Bsbios & 70.000 & $12,7 \%$ & 125.475 .000 & $13,1 \%$ & $1.792,50$ \\
\hline Caramuru & 30.000 & $5,5 \%$ & 53.678 .700 & $5,6 \%$ & $1.789,29$ \\
\hline Fiagril & 27.500 & $5,0 \%$ & 48.981 .650 & $5,1 \%$ & $1.781,15$ \\
\hline Oleoplan & 10.000 & $1,8 \%$ & 17.989 .800 & $1,9 \%$ & $1.798,98$ \\
\hline $\begin{array}{r}\text { Total } \\
\end{array}$ & 550.000 & $100,0 \%$ & 960.664 .159 & $100,0 \%$ & $1.746,66$ \\
\hline
\end{tabular}

Tabela 26 - Resultado leilão da ANP (11-12/julho/06)

Fonte: ANP 
O preço médio encontrado na tabela será considerado no modelo proposto no item anterior, sofrendo algumas modificações como: custo de produção do biodiesel, preço praticado no leilão em cada região e taxa de imposto incidente. O modelo proposto será mantido:

- Estruturas de capital: o valor a ser financiado será o mesmo em todas as regiões;

- Investimento: a tecnologia empregada é a mesma, difere o valor da terra, mas não foi considerada esta diferença no modelo, todos os insumos se aplicam a mesma tecnologia;

- Índice de produtividade: foi considerado o mesmo para todas as regiões;

- Custos Fixos, Despesas, Depreciação: todos estes dados são mantidos, pois diferem pouco e não de forma significativa.

- A instalação contempla apenas o processo do óleo para o biodiesel, ou seja, não inclui a planta de esmagamento.

- Foram calculados 14 anos de projeção do fluxo de caixa e valor residual com fluxo constante a partir de 2021.

- Foram considerados produção empresarial, ou seja, não considerado cultura familiar neste específico caso, existe incentivos aumentando mais as margens.

$\mathrm{Na}$ tabela encontra-se o quadro das principais premissas.

\begin{tabular}{|llccc|}
\hline Região & Fonte & Imp (\%) & Custo R\$/L & Preço R\$/L \\
\hline Norte & Dende & $8,85 \%$ & 1,175 & 1,730 \\
Nordeste & Algodão & $8,85 \%$ & 0,932 & 1,730 \\
Nordeste & Mamona & $8,85 \%$ & 1,374 & 1,730 \\
Sudeste & Soja & $13,28 \%$ & 0,838 & 1,790 \\
Sudeste & Girassol & $13,28 \%$ & 0,815 & 1,790 \\
Sul & Soja & $13,28 \%$ & 0,838 & 1,762 \\
Sul & Girassol & $13,28 \%$ & 0,815 & 1,762 \\
Centro-Oeste & Soja & $11,32 \%$ & 0,838 & 1,780 \\
\hline
\end{tabular}

Tabela 27 - Parâmetros do modelo comparativo por região e produto.

Fonte: ANP e PENTEADO, MAURÍCIO (2006).

$\mathrm{Na}$ tabela, foram calculados os valores para cada região, bem como o tipo de insumo para a fabricação do biodiesel. 


\begin{tabular}{|c|c|c|c|c|c|c|c|c|}
\hline 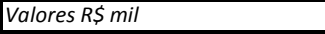 & N-Dendê & NE-Algodão & NE-Mamona & SE-Soja & SE-Girassol & S-Soja & S-Girassol & CO-Soja \\
\hline Total Fluxo Caixa Projetado & 80.994 & 111.896 & 55.484 & 114.212 & 117.178 & 113.517 & 116.483 & 118.921 \\
\hline Total Resíduo Projetado & 34.152 & 43.736 & 26.288 & 43.867 & 44.789 & 43.792 & 44.714 & 45.505 \\
\hline Total Valor Empresa & 115.146 & 155.632 & 81.772 & 158.079 & 161.967 & 157.310 & 161.198 & 164.426 \\
\hline (-) Dívida & $(17.250)$ & $(17.250)$ & $(17.250)$ & $(17.250)$ & $(17.250)$ & $(17.250)$ & $(17.250)$ & $(17.250)$ \\
\hline Valor Acionista (Met. Empresa) & 97.896 & 138.382 & 64.522 & 140.829 & 144.717 & 140.060 & 143.948 & 147.176 \\
\hline Valor Acionista & 92.812 & 132.107 & 60.599 & 134.691 & 138.473 & 133.879 & 137.661 & 140.814 \\
\hline Diferença (\%) & $5,5 \%$ & $4,8 \%$ & $6,5 \%$ & $4,6 \%$ & $4,5 \%$ & $4,6 \%$ & $4,6 \%$ & $4,5 \%$ \\
\hline Capacidade média em m3 & 23.138 & 23.138 & 23.138 & 23.138 & 23.138 & 23.138 & 23.138 & 23.138 \\
\hline Total Valor Empresa $\mathbf{R} \$ \mathrm{mil} / \mathrm{m} 3$ & 4,98 & 6,73 & 3,53 & 6,83 & 7,00 & 6,80 & 6,97 & 7,11 \\
\hline Valor Acionista (Met. Empresa) & 4,23 & 5,98 & 2,79 & 6,09 & 6,25 & 6,05 & 6,22 & 6,36 \\
\hline \multirow[t]{2}{*}{ Valor Acionista R\$mil/m3 } & 4,01 & 5,71 & 2,62 & 5,82 & 5,98 & 5,79 & 5,95 & 6,09 \\
\hline & $(\%)$ & $(\%)$ & $(\%)$ & $(\%)$ & $(\%)$ & $(\%)$ & $(\%)$ & $(\%)$ \\
\hline Total Fluxo Caixa Projetado & $70,3 \%$ & $71,9 \%$ & $67,9 \%$ & $72,3 \%$ & $72,3 \%$ & $72,2 \%$ & $72,3 \%$ & $72,3 \%$ \\
\hline Total Resíduo Projetado & $29,7 \%$ & $28,1 \%$ & $32,1 \%$ & $27,7 \%$ & $27,7 \%$ & $27,8 \%$ & $27,7 \%$ & $27,7 \%$ \\
\hline Total Valor Empresa & $100,0 \%$ & $100,0 \%$ & $100,0 \%$ & $100,0 \%$ & $100,0 \%$ & $100,0 \%$ & $100,0 \%$ & $100,0 \%$ \\
\hline
\end{tabular}

Tabela 28 - Comparativo entre diferentes regiões e insumos.

Fonte: Produzida pelo autor

O complexo soja liderada o ranking de maior valor por $\mathrm{m}^{3}$ de capacidade, principalmente na região Centro-Oeste, onde encontra-se a maior produção do grão no Brasil. Seguidos pelo Sudeste por encontrar o principal mercado do biodiesel, bem como a posição estratégia de muitas empresas fornecedoras do óleo e mercado para o farelo. Seguindo o Sul, por ser a segunda região mais importante na produção de soja e escoamento do produto.

A região Nordeste destaca-se a cultura do algodão como fonte de matéria prima para o biodiesel, além disso, destaca-se a mamona como cultura alternativa familiar dentro do programa estratégico do governo de desenvolvimento regional. Este último difere dos demais por ter incentivos na cultura familiar, ou seja, os impostos tendem a zero caso seja utilizado cultura familiar, elevando assim a relação valor da empresa sobre a capacidade de biodiesel produzido.

Portanto, esta tabela serve de referencial para o cálculo do valor da empresa apresentando as seguintes variáveis no modelo: fonte de matéria-prima, região geográfica, estrutura de capital, preço de contrato de venda no leilão e incentivos fiscais

\subsection{Avaliação pela Teoria das Opções}

Segundo o preceito de COPELAND ET AL (1994) de que a identificação de uma atividade empresarial para a aplicação da Teoria de Opções Reais pressupõe flexibilidade, constata-se 
que empresas com características como as de uma usina de biodiesel restringem a possibilidade do emprego deste método de avaliação, dada a rígida inflexibilidade do modelo empresarial identificado neste tipo de empresa.

A demanda garantida para os próximos anos e os contratos de fornecimento para a Petrobras eliminam riscos específicos do negócio, garantindo significativamente previsibilidade nos resultados. Cada uma das formas de opções empresarial definidas por COPELAND ET AL. (1994) pode ser refutada. A opção de adiar o investimento praticamente inexiste, dado que o cronograma de montagem da usina é curto e necessita de um projeto final para iniciar a produção. A opção de expandir não foi considerada no modelo, pois em razão da natureza da usina, viabiliza a construção de uma nova usina para melhor aproveitar a logística de transporte. A opção de contratar ou de alternância de produção não se aplica, já que o setor irá passar por uma expansão e um mercado garantido, inviabilizando a escolha de não produção dado a característica do negócio e o intensivo investimento em equipamentos. O único tipo de opção aplicável a usina - a de abandonar - é inviável.

Assim, a impossibilidade de identificação de flexibilidade na forma de opções da empresa desqualifica o método de avaliação pela Teoria de Opções Reais como uma alternativa à estimativa do valor de negociação da empresa.

\subsection{Avaliação de empresa pelo Valor Contábil}

A avaliação pelo método do Valor Contábil definida por CORNELL (1994) propõe a estimativa de um valor supondo que o novo detentor das ações ordinárias da empresa deva liquidar os compromissos totais assumidos pelos antigos detentores. Em outras palavras, não supõe a continuidade das dívidas, propiciando assim um valor significativamente mais elevado. Como no setor de biocombustíveis é comum o elevado nível de endividamento das empresas, tal consideração tende a proporcionar a mesma disparidade de valor observado neste estudo de caso para quaisquer empresas avaliadas no setor.

Supondo que o método de CORNELL com a suposição de que a estrutura da dívida possa permanecer a mesma independentemente do detentor de ações ordinárias, pode-se desenvolver uma nova estimativa para o valor contábil da empresa, considerando apenas o valor contábil de seu Patrimônio Líquido apresentam valores não confiáveis. 
Há de se destacar algumas limitações do método do valor contábil, dentre elas: a não observância do custo de oportunidade do capital investido; a valoração baseada no princípio do custo histórico, que supõe a invariabilidade no tempo dos valores investidos; a inobservância do horizonte de resultados previstos posteriormente à data de avaliação. 


\section{APLiCAÇÃo do MODELO de AVALIAÇÃo de EMPRESAS NO SETOR DE BIOCOMBAGRSTÍVEIS - ÁLCOOL}

Neste capitulo, são apresentadas as características e estudos de viabilidade econômica de empresas do setor de álcool. O estudo passa pela formulação de um modelo econômico para aplicação dos modelos de avaliação uma vez que estas empresas convergem para um modelo de mercado - empresas que pertencem a um setor de commodities em formação e de capital fechado.

De todos os biocombustíveis citados, o álcool é o que merece maior destaque por ser um produto passando por um importante momento de destaque iniciado na década de 70, desca-se como substituição de combustíveis em maior escala, sem contar o potencial do mercado internacional em desenvolvimento.

O trabalho aqui desenvolvido baseou-se na avaliação prática de uma empresa setor de álcool, sendo estruturado por premissas de outras empresas do mesmo setor.

O trabalho foi desenvolvido com base na metodologia de fluxo de caixa descontado e não envolveu a avaliação de ativos da Empresa, inclusive das terras próprias. A avaliação foi de $100 \%$ do capital da Usina e não foi considerado qualquer desconto que poderia ser aplicável a participações minoritárias.

Da mesma forma, no trabalho não foi considerado qualquer desconto por falta de liquidez que poderia ser aplicado a participação objeto de negociação pelo fato de a Usina não ter capital negociado em bolsa.

O trabalho de avaliação da Usina foi desenvolvido para a data-base de 31 de dezembro de 2006, com base em informações fornecidas pela administração da Empresa, e incluiu:

- Apreciação de informações financeiras e dados gerenciais históricos da empresa relativos aos anos fiscais encerrados em dezembro de 2004, 2005 e 2006. Dados específicos de outros anos também foram analisados;

- Entendimento de informações sobre a idade média da cana de açúcar, rotatividade das terras, rendimento agrícola e outros índices relevantes; 
- Leitura dos informes de mercado, publicados ou disponíveis, a respeito do setor de açúcar e álcool;

- Processamento das projeções no modelo de avaliação proposto neste trabalho;

- Identificação, análise e discussão dos principais riscos decorrentes das premissas adotadas;

- Análise dos resultados obtidos e desenvolvimento de estudos de sensibilidade julgados necessários.

- Projeção de 14 anos, ou seja, até 2020.

O trabalho a Usina foi avaliada considerando as operações agrícola e industrial como negócios separados da propriedade de terras. Desta forma, para o cálculo do valor da operação, foi considerada a redução do fluxo de caixa do negócio pelo custo hipotético de arrendamento das terras próprias.

Os dados são sigilosos, pois todas as empresas envolvidas na pesquisa são de capital fechado. Ainda no Brasil, este setor passa por um processo de profissionalização incluindo abertura de capital. Apenas duas empresas deste setor estão listadas na Bolsa de Valores de São Paulo (BOVESPA), facilitando o acesso às informações do seu negócio:

Da mesma forma que o cálculo do biodiesel, com o objetivo de centrar o estudo nos métodos de avaliação e não em características acessórias - como particularidades contábeis e aspectos macroeconômicos - algumas premissas simplificadoras foram adotadas neste trabalho. As mesmas serão citadas neste capítulo na medida em que ocorrerem, possibilitando futuras avaliações.

Informações técnicas e comportamento do setor foram baseados em artigos técnicos e consulta a especialista do setor, incluindo workshop, feiras e congressos. Dados de preços e alíquotas forma levantados com base nos contratos do setor e a ANP (Agencia Nacional do Petróleo). As demais informações forma obtidas junto a órgãos reguladores e fiscalizadores, que serão citados neste trabalho na medida em que as informações obtidas sejam empregadas. 
Finalizando o estudo do tópico do setor de álcool serão analisadas empresas em diferentes regiões do Brasil para chegar-se a um múltiplo de valor por produção. O modelo teórico será criado baseado nos parâmetros da Usina em estudo.

\subsection{Apresentação da Empresa}

A Usina foi fundada em 1898, com sede na região de Campinas-SP, e tem como atividade a exploração agrícola da cana-de-açúcar para a produção de açúcar, álcool e respectivos subprodutos, cuja comercialização é efetuada nos mercados interno e externo.

Na safra de 2005/06 a usina moeu 1,5 milhões de toneladas de cana-de-açúcar, produziu 2 milhões de sacas de açúcar e 61 milhões de litros de álcool. A Usina encerrou o exercício de 2006 com receita líquida de R 114 milhões e lucro líquido de $\mathrm{R}$ \$ 8,4 milhões.

O estudo em questão pode ser generalizado tendo em vista apenas algumas premissas variáveis no tempo como é o caso do preço da cana de açúcar, preço do açúcar e álcool e produtividade da terra.

\subsection{Parametrização do Caso Base}

Este caso reflete as principais características do projeto, tendo sido desprezadas peculiaridade não aplicáveis à outras empresas e cuja omissão não representa valores significativos para o fluxo de caixa.

A empresa em questão não faz parte dos grandes grupos e tem um grande potencial para ser adquirida por outro grupo, dado a consolidação do setor. De acordo com o relatório anual da UNICA (União das Indústrias de Cana) em 2005 a usina estava entre a posição 70-80 em volume de moagem de cana. Quanto a sua participação no mercado, podemos avaliar na tabela. 


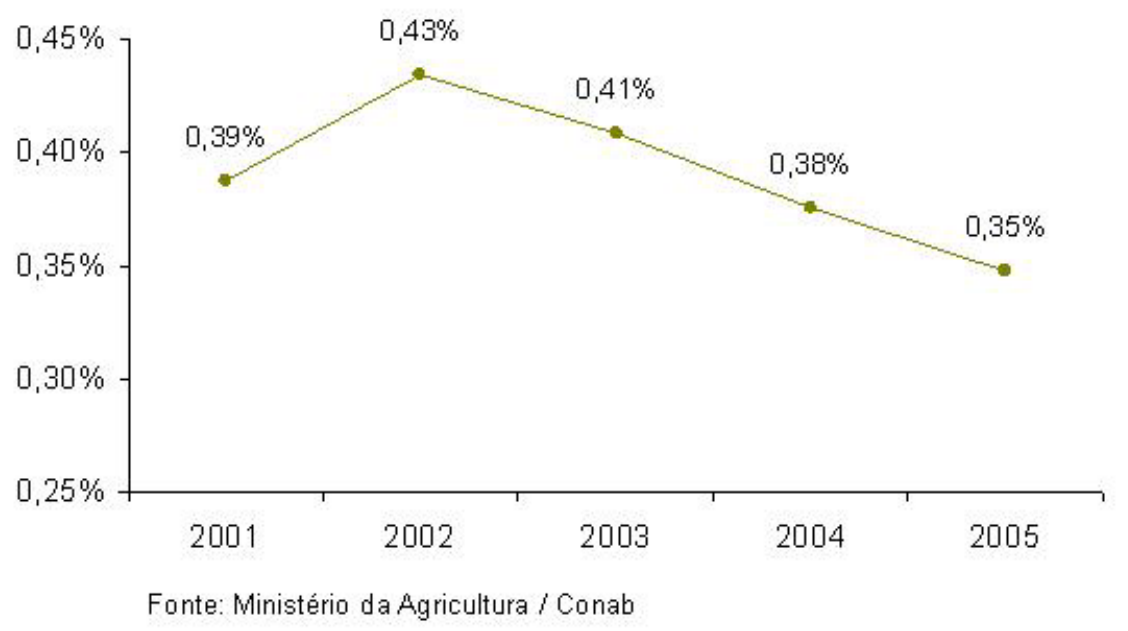

Gráfico 12 - Market share em moagem de cana no Brasil

Fonte: Ministério da Agricultura/Conab

A seguir serão discutidos os parâmetros iniciais da usina de álcool, bem como as premissas adotadas para o cálculo do valor da mesma.

\subsubsection{Produção e produtos comercializados}

A projeção para o cálculo da receita inicia-se com a capacidade de moagem, ou seja, as fontes e origens da cana. De acordo com o histórico de produtividade da empresa é possível estimar os seguintes valores:

A empresa possui três fontes de fornecimento de cana: cana própria, ou seja, produção em terra própria, terra de parceiros, neste caso terra arrendada por um determinado período dentro de um contrato e cana de terceiros, neste caso comprada do mercado para atender a capacidade instalada.

O cálculo de produtividade foi baseado nos dados históricos e comparado com os índices da região para parceiros - terras arrendadas. Neste caso, a produtividade das terras próprias tem um valor menor devido a colheita ser feita no método convencional, enquanto a colheita de terceiros é feita com colheita mecanizada, isto garante, maior produtividade (ÚNICA, 2007).

- Terra própria - 92,1 ton/ha; 
- Terras arrendadas - 92,9 ton/ha.

Na tabela é apresentado o mix de fontes de insumos para atender a demanda da usina.

\begin{tabular}{|c|c|c|c|c|c|c|c|c|c|c|c|}
\hline ANO & 2007 & 2008 & 2009 & 2010 & 2011 & 2012 & 2013 & 2014 & 2015 & 2016 & 2017 \\
\hline Área Total (ha) & 13.477 & 13.595 & 13.715 & 13.836 & 13.958 & 14.080 & 14.080 & 14.080 & 14.080 & 14.080 & 14.080 \\
\hline Área Própria (ha) & 6.582 & 6.582 & 6.582 & 6.582 & 6.582 & 6.582 & 6.582 & 6.582 & 6.582 & 6.582 & 6.582 \\
\hline Área Parceiros (ha) & 6.895 & 7.013 & 7.133 & 7.254 & 7.376 & 7.498 & 7.498 & 7.498 & 7.498 & 7.498 & 7.498 \\
\hline Prod. Própria (ton/ha) & 92,1 & 92,1 & 92,1 & 92,1 & 92,1 & 92,1 & 92,1 & 92,1 & 92,1 & 92,1 & 92,1 \\
\hline Prod. Parceiros (ton/ha) & 92,9 & 92,9 & 92,9 & 92,9 & 92,9 & 92,9 & 92,9 & 92,9 & 92,9 & 92,9 & 92,9 \\
\hline Cana Total (ton) & 1.610 .046 & 1.639 .238 & 1.669 .435 & 1.700 .684 & 1.733 .033 & 1.766 .533 & 1.766 .533 & 1.766 .533 & 1.766 .533 & 1.766 .533 & 1.766 .533 \\
\hline Cana Própria & 605.940 & 605.940 & 605.940 & 605.940 & 605.940 & 605.940 & 605.940 & 605.940 & 605.940 & 605.940 & 605.940 \\
\hline Cana Parceira & 640.759 & 651.784 & 662.905 & 674.124 & 685.443 & 696.860 & 696.860 & 696.860 & 696.860 & 696.860 & 696.860 \\
\hline Cana Fornecedor & 363.347 & 381.514 & 400.590 & 420.620 & 441.651 & 463.733 & 463.733 & 463.733 & 463.733 & 463.733 & 463.733 \\
\hline
\end{tabular}

Tabela 29 - Mix de insumos de cana-de-açúcar.

Fonte: Produzida pelo autor

$\mathrm{Na}$ área de terceiros - parceiros o valor converge para um maior ganho de produtividade, acompanhando os índices da região com colheita mecanizada.

\subsubsection{Estratégias de Produção}

As premissas para o cálculo do valor da empresa seguem uma política de crescimento da capacidade da empresa:

- Aumento de 5\% ao ano no volume de cana captada de fornecedores entre 2006 e 2011 mantendo tendência histórica e refletindo crescimento já observado em 2006. Manutenção em 2012 do volume de cana captada de fornecedores em 2011, de 441.651 toneladas.

- Manutenção da quantidade de cana fornecida pelos parceiros e terras próprias.

- Manutenção do mix observado em 2005, 40\% para álcool e $60 \%$ para açúcar, ao longo do período projetado

- Manutenção dos índices de produtividade industrial de 2005 para o período projetado, resultando em taxas de 114,5 quilogramas de açúcar (2,29 Unicops) por tonelada de cana e 104,9 litros de álcool (3,28 Unicops) por tonelada de cana.

Baseado na capacidade de moenda da cana, chega-se as seguintes mix de produtos ao longo dos anos de projeção. 


\section{Volume produzido açúcar e álcool}

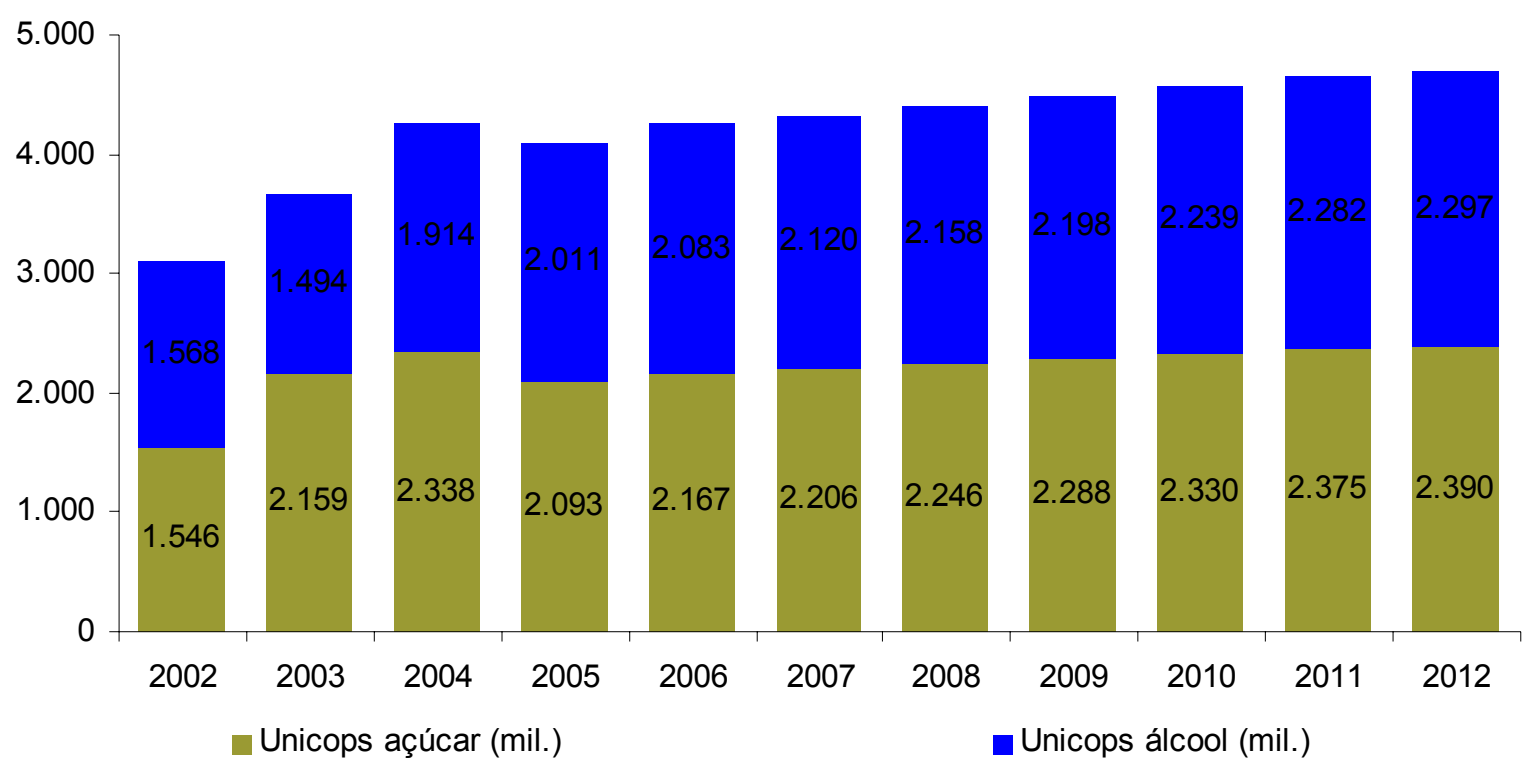

Gráfico 13 - Relação de Produção de Álcool e Açucar.

Fonte: Produzida pelo autor

Existe uma nova tecnologia em estudo para a hidrólise do bagaço que irá duplicar a produção de álcool em uma usina convencional, mas esta mudança requer capital na ordem de grandeza de uma nova usina. Além disso, esta tecnologia estará disponível apenas na virada 2009/2010.

\subsubsection{Preço de Venda}

Os preços de vendas foram baseados seguindo previsões do próprio setor (ÚNICA, 2007), porém foi adotado um viés conservador, mesmo o setor apresentando forte crescimento de demanda para os próximos anos, pelas seguintes razões:

- Frota de veículos leves sendo produzidos na forma de biocombustível (flex-fuel), de acordo com a ANFAVEA em 2006 foram produzidos 83,7\% de veículos deste tipo no Brasil;

- Mistura de álcool à gasolina brasileira, com tendência a ser aumentada nos próximos meses, proporção de $25 \%$;

- Insumo para a produção do biodiesel, com crescimento elevado; 
- Novos mercados com a introdução da mistura álcool em países como: Japão, Comunidade Européia, entre outros.

- Abaixo gráfico apresentando os preços de etanol e gasolina.

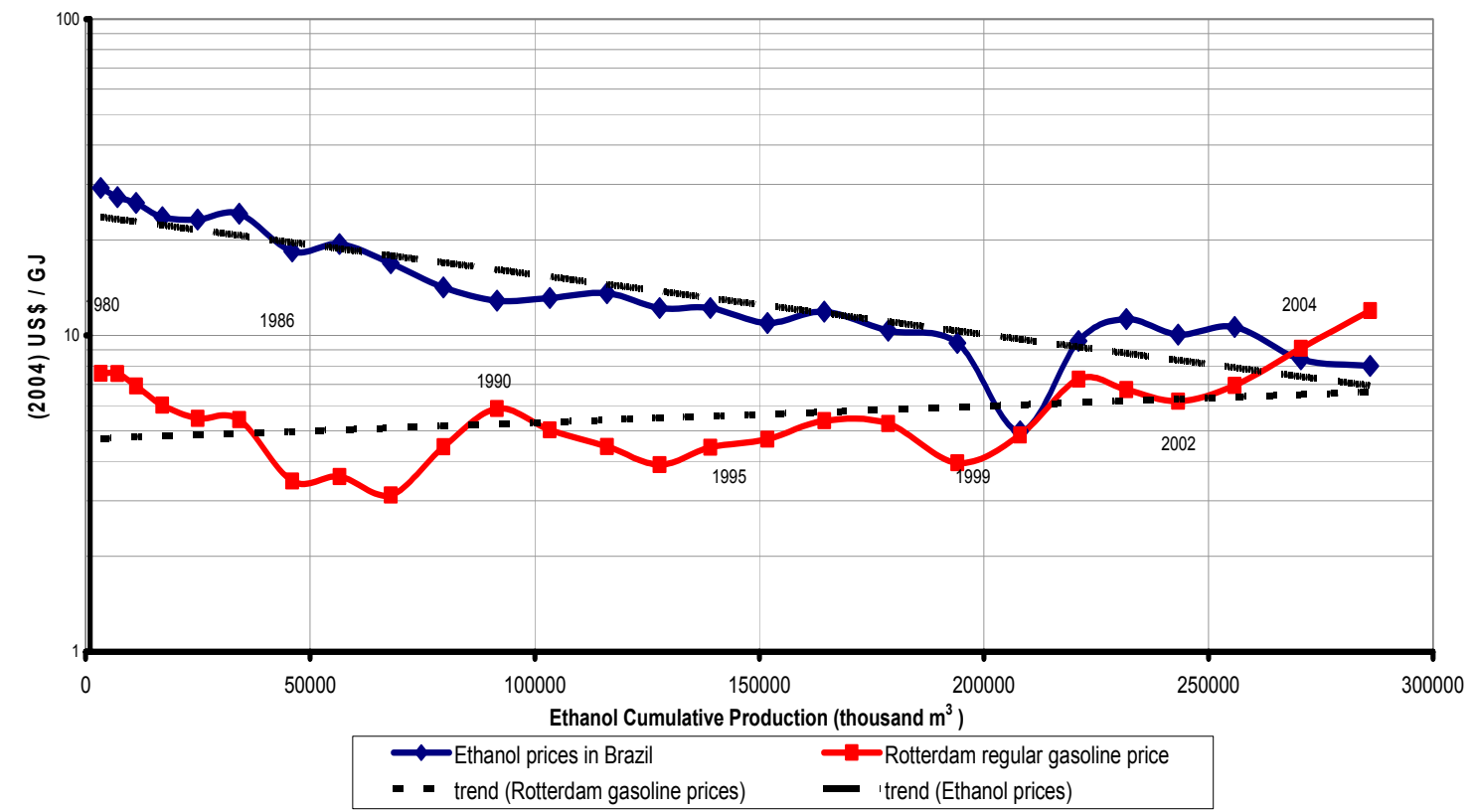

Gráfico 14: Competitividade Internacional - Curva de Aprendizado do Etanol Fonte: Nastari, 2005 (Etanol Hidratado)

Cabe ressaltar que diferente do modelo do Proálcool que no futuro ao lançamento do programa na década de 70, apareceram distorções de cunho político. Naquele momento o objetivo era a necessidade de substituição do petróleo importado num momento de vulnerabilidade econômica no país, que em pouco mais de uma década deixou de ser problema devido a queda do preço do barril. O cenário marcado pela política atual visa um novo objetivo de redução da poluição nos grandes centros urbanos, desenvolvimento regional e social. Além de colocar o Brasil como fonte de um combustível importante no cenário global. 


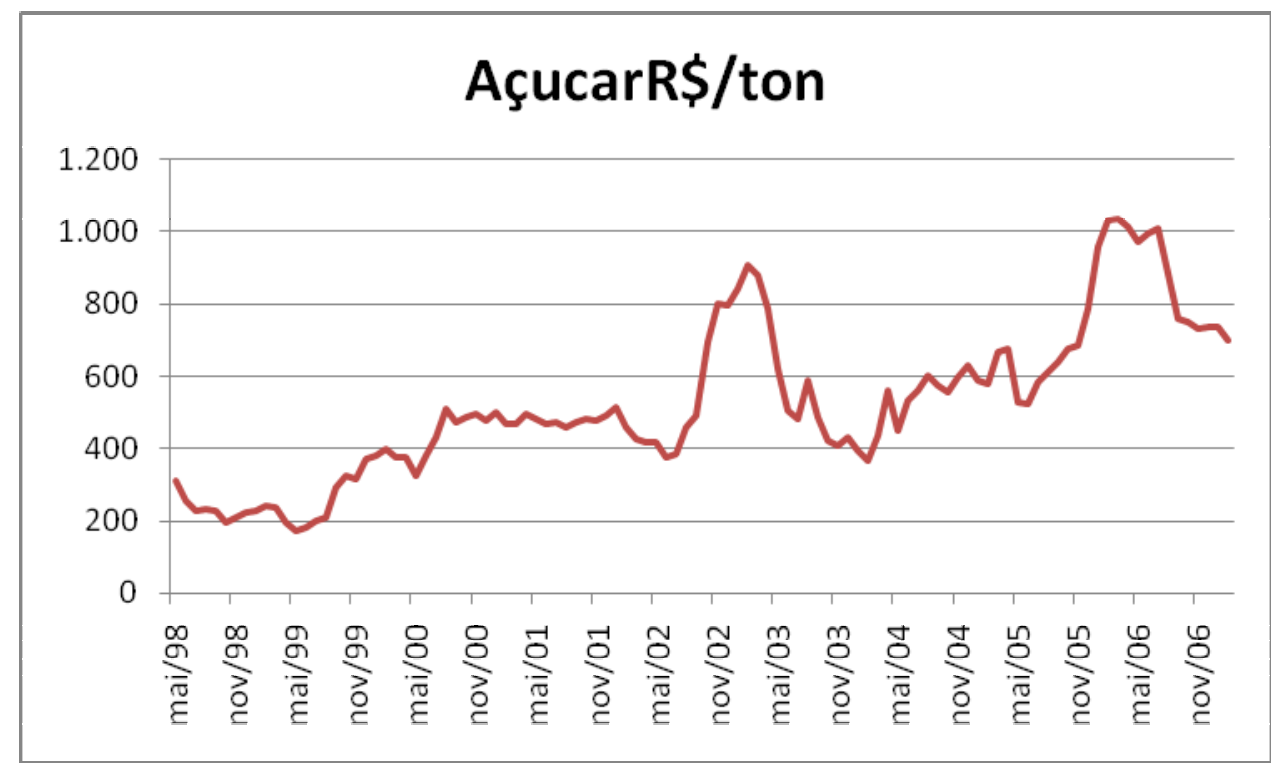

Gráfico 15 - Preço do Açúcar R\$/ton

Fonte: ESALQ /CEPEA - Estado de São Paulo

Obs: Açúcar - preços de faturamento inclusive PIS/COFINS, ICMS e IPI

O preço do açúcar em média dos últimos 12 meses registrou patamares da ordem de R \$859/ton. No modelo foram considerados valores próximos a R \$755/ton (12\% de redução). Decidiu apostar num viés conservador, mesmo com o aumento da relação álcool/açúcar, em que pode ocorrer pressão de demanda, além disso, esses valores ficaram próximos aos valores de 2005 e 2004.

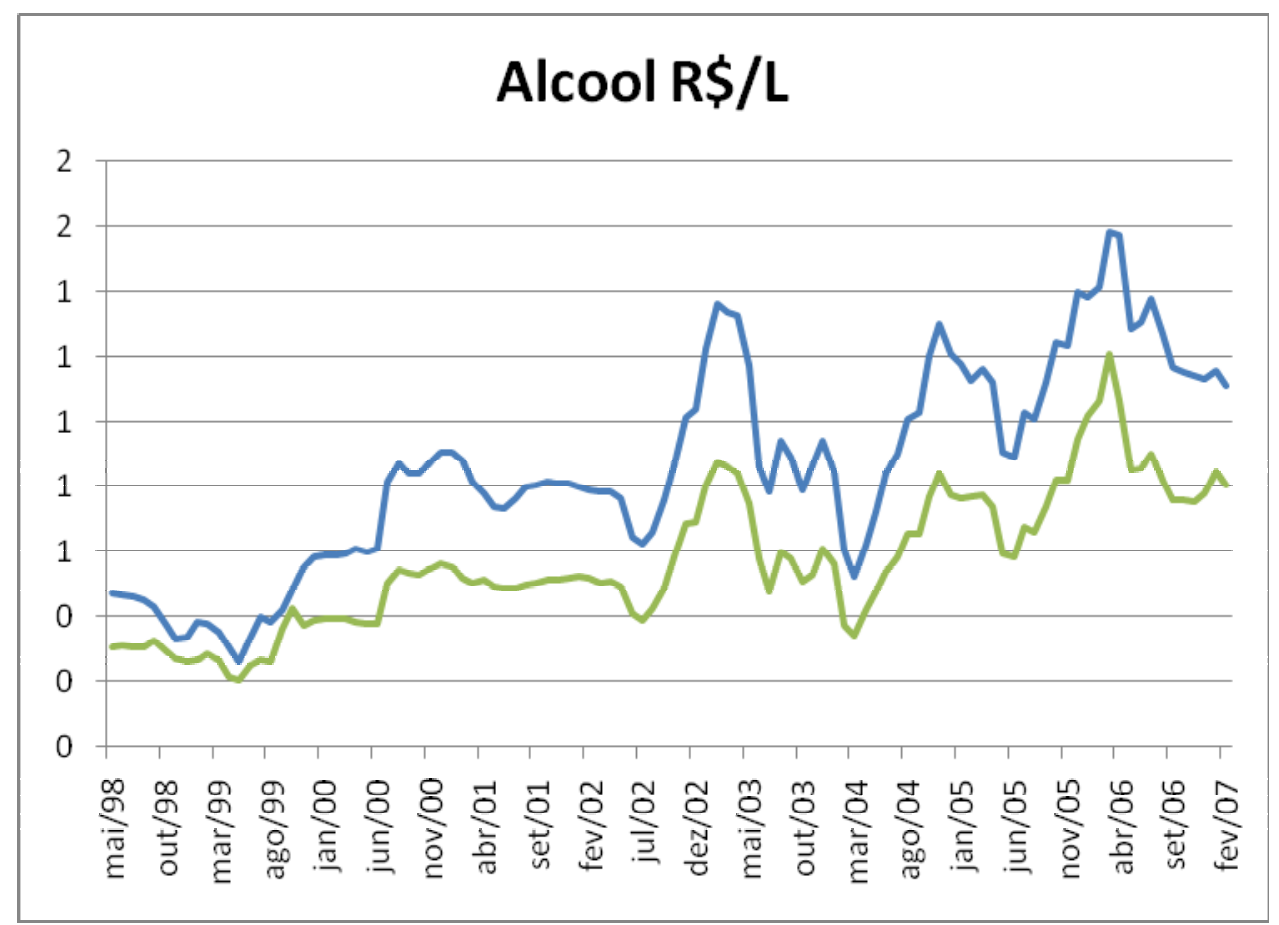

Gráfico 16 - Preço álcool R\$/L

Fonte: ESALQ /CEPEA - Estado de São Paulo

Obs: Álcool - preços de faturamento, sem impostos (PIS/COFINS e ICMS) 
O preço do álcool, apesar da entrada de novas usinas irá sofrer pressão de demanda por parte dos agentes já mencionados anteriormente. "Preços maiores desse produto direcionam a cana para a produção de álcool, sendo que, em sentido inverso, aumenta-se a produção de açúcar em detrimento da produção de álcool" (Moraes, 2002). O preço médio dos últimos 12 meses do álcool anidro oscilou próximo de R \$ 1,27/litro (s/ impostos), redução de 14\% na projeção. A partir de 2010 o preço encontra-se na faixa de $\mathrm{R} \$ 1,02 /$ Litro.

A projeção dos dados futuros é feita baseada na premissa de não adoção de novas tecnologias para os próximos anos, mesmo assim considerou ganhos de produtividade agrícola ao longo do horizonte de projeção. Portando, a receita sofrerá variações de risco apenas na variável preço, já que estimou a venda de toda a capacidade produtiva com aumento de produtividade.

\subsubsection{Tributos}

\section{Imposto sobre a Receita}

No modelo proposto supõe valores percentuais fixos ao longo dos anos de projeção. Na tabela apresenta as alíquotas de impostos praticados.

\begin{tabular}{lrrrr} 
Aliquotas por produto & \multicolumn{1}{c}{ ICMS } & \multicolumn{1}{c}{ IPI } & \multicolumn{1}{c}{ PIS } & COFINS \\
\hline Açúcar & $7,00 \%$ & $5,00 \%$ & $1,65 \%$ & $7,60 \%$ \\
Álcool Neutro & $18,00 \%$ & $8,00 \%$ & $1,65 \%$ & $7,60 \%$ \\
Álcool Industrial & $12,00 \%$ & $0,00 \%$ & $1,65 \%$ & $7,60 \%$ \\
Álcool Carburante & $18,00 \%$ & $\mathrm{~N} / \mathrm{T}$ & $1,65 \%$ & $7,60 \%$ \\
Álcool Destilado & Diferido & Suspenso & $1,65 \%$ & $7,60 \%$ \\
Bagaço de Cana & $18,00 \%$ & $\mathrm{~N} / \mathrm{T}$ & $1,65 \%$ & $7,60 \%$
\end{tabular}

$\mathrm{N} / \mathrm{T}$ - não tributado

Tabela 30 - Tabela de tributos para o açúcar/álcool.

Fonte: Produzido pelo Autor

\section{Imposto de Renda}

- $\quad 15 \%$ sobre o lucro tributável até o limite anual de R\$ 240 mil;

- $25 \%$ sobre lucro excedente a $\mathrm{R} \$ 240$ mil.

\section{Contribuição Social}

- $9 \%$ sobre o lucro tributável. 


\subsubsection{Custo de operação da usina de álcool}

Para o cálculo dos custos de produção do açúcar/álcool, podemos dividir em duas componentes principais para efeito de estudo: custos agrícolas e custos industriais. A importância dos custos agrícolas neste segmento dos biocombustíveis é importante, pois estes definem em média $80 \%$ dos custos de produção do açúcar/álcool a partir do plantio da cana.

O passo seguinte foi o cálculo detalhado dos custos de produção de cada matéria-prima agrícola - custo do produto in natura ao chegar na unidade de produção do açúcar/álcool.

Para o cálculo dos custos agrícolas principais, foi dividido nos seguintes tópicos:

- Colheita: projetado variando em linha com o volume de cana moída própria, de parceiros e de fornecedor de cana em pé, mantido em $\mathrm{R} \$ 12,6$ por tonelada ao longo de todo o período projetado;

- Arrendamento e parceria: projetado em linha com o volume de cana de parceiros e variações de preço de venda dos produtos. Em 2006 estes custos contemplam um aumento de $30 \%$ no custo da tonelada;

- Tratos: os desembolsos com custos de trato são registrados em estoque e contabilizados como custo no período subseqüente. Projetado mantendo o custo de tratos em R\$ 1.341 por hectare de área tratada ao longo de todo o período projetado, conforme valores observados em 2006.

- Cana de Fornecedores: variando em linha com o volume de cana de fornecedores e variação de preços de venda dos produtos

Outro custo importante é o processo de moagem, fermentação e separação dos produtos que passaremos a classificá-los e como sendo custos industriais. Estes custos representam em média $20 \%$ dos custos totais.

- Mão de obra: crescimento real de $2 \%$ ao ano até 2012 ;

- Sacaria: projetado em linha com o volume de açúcar exportado, mantido custo de $\mathrm{R} \$ 20$ por tonelada; 
- Manutenção industrial: crescimento de 5\% ao ano até 2012;

- Custos projetados em linha com o volume total de cana moída:

O Materiais: R\$ 0,09 por tonelada;

○ Despesas Diversas: R\$ 0,07 por tonelada;

○ Insumos: $\mathrm{R} \$ 0,40$ por tonelada;

- Utilidades (geração de vapor e eletricidade): R $\$ 0,80$ por tonelada;

Outros custos foram considerados como é o caso do custo do arrendamento da terra própria.

- Produtividade: 50 toneladas por alqueire;

- Teor de sacarose: $121 \mathrm{~kg} /$ ATR por tonelada;

- Preço do ATR: considerado R\$ 0,29 por ATR, média de 2005, e variando em linha com o preço de Unicop para o período projetado.

\subsubsection{Despesas e Depreciação}

\section{Despesas comerciais}

- Comissões: rescisão do contrato com parceiro comercial do Rio de Janeiro em 2005. O valor de R $\$ 800$ mil em 2006 refere-se ao acordo de rescisão;

- Fretes: projetado em linha com o volume de álcool para mercado interno, exceto carburante, ao custo de $\mathrm{R} \$ 0,02$ por litro;

- Despesas de exportação: projetada em linha com volume de exportações a R \$ 2,33 por Unicop;

- Pessoal: crescimento real de $2 \%$ ao ano até 2012 ;

- Outras despesas: projetadas constantes em R\$ 387 mil reais, média entre 2005 e 2006. 


\section{Despesas administrativas}

- Pessoal: crescimento real de $2 \%$ ao ano até 2012 ;

- Outras: segundo a administração da Empresa, a conta outros em despesas administrativas refere-se em sua maioria a despesas jurídicas. O restante da conta refere-se a miscelâneas. Entre 2004 e 2006 esta conta de despesa se manteve no mesmo patamar e, desta forma, adotou-se o valor de 2006, constante, para o período de projeção.

\subsubsection{Investimento}

\section{Plantio}

- Projetado em linha com o nível de desembolso em 2005, resultando em R\$2.750 por hectare de terra plantada;

- Premissa de renovação da área de plantio a cada 4 anos.

\section{Ativos fixos}

- Investimentos de R\$ 3 milhões por ano para manutenção do parque industrial e máquinas e equipamentos agrícolas

- Investimento de $\mathrm{R} \$ 50$ milhões dividido em 5 parcelas anuais a partir de 2007 sendo aproximadamente $70 \%$ para geração de vapor (substituição de caldeira) e o restante para instalação de um novo gerador de energia de capacidade acima da atual (visando a atender crescimento projetado)

Distribuição dos investimentos projetados:

\begin{tabular}{lrrrrrrrr} 
Investimentos - R\$ mil & $\mathbf{2 0 0 7}$ & $\mathbf{2 0 0 8}$ & $\mathbf{2 0 0 9}$ & $\mathbf{2 0 1 0}$ & $\mathbf{2 0 1 1}$ & $\mathbf{2 0 1 2}$ & $\mathbf{2 0 1 3}$ & POS \\
\hline Ativo fixo - Industria & 1.000 & 1.000 & 1.000 & 1.000 & 1.000 & 1.000 & 1.000 & 1.000 \\
Ativo fixo - geração de vapor e eletricid & - & 10.000 & 10.000 & 10.000 & 10.000 & 10.000 & - & - \\
Ativo fixo - equipamentos agrícolas & 2.000 & 2.000 & 2.000 & 2.000 & 2.000 & 2.000 & 2.000 & 2.000 \\
Renovação de lavoura & 7.721 & 7.789 & 7.857 & 7.926 & 7.996 & 8.067 & 8.138 & 8.138 \\
\hline TOTAL & $\mathbf{1 0 . 7 2 1}$ & $\mathbf{2 0 . 7 8 9}$ & $\mathbf{2 0 . 8 5 7}$ & $\mathbf{2 0 . 9 2 6}$ & $\mathbf{2 0 . 9 9 6}$ & $\mathbf{2 1 . 0 6 7}$ & $\mathbf{1 1 . 1 3 8}$ & $\mathbf{1 1 . 1 3 8}$
\end{tabular}

Tabela 31 - Distribuição de Investimento

Fonte: Produzido pelo Autor 


\subsubsection{Endividamento Projetado}

- Soma dos três componentes de dívida, com limite inferior de 1,5 vezes o EBITDA sustentável e ajustado da empresa, mais a dívida do PESA

- EBITDA sustentável é o EBITDA estabilizado, ou seja, de R $\$ 34$ milhões, projetado para o período de 2011 em diante (após incrementos e reduções de preço estimadas para os anos de 2007 a 2010);

- EBITDA ajustado é o EBITDA deduzido dos desembolsos anuais para pagamento do PAES.

- A projeção do endividamento da empresa resulta da projeção dos seus três principais componentes de dívida: PESA (plano especial de saneamento de ativos), BNDES e dívida operacional

- Dívida BNDES: relativa ao financiamento de ativo fixo para equipamento de geração de vapor e eletricidade. Projetada considerando financiamento de $70 \%$ do investimento, com prazo de carência de 2 anos e 5 anos para pagamento. A taxa de juros considerada foi TJLP (ajustada para taxa real) mais $3 \%$ de spread

- Dívida PESA: projetada no mesmo montante de dezembro de 2005, de R\$ 16 milhões, durante todo o período, com vencimento em 1 de novembro de 2022 (juros pagos anualmente)

- Dívida operacional: projetada em 1,0 vez o EBITDA sustentável e ajustado da empresa, podendo atingir até 1,5 vezes para sustentar a premissa de dívida total mínima (ocorre a partir de 2018, data em que a dívida com o BNDES já está quitada e ocorre a liquidação integral do PAES)

- Caixa no início do ano suficiente para 15 dias de custos e despesas 


\begin{tabular}{|c|c|c|c|c|c|c|c|}
\hline Dívida em 31 Dezembro & 2007 & 2008 & 2009 & 2010 & 2011 & 2012 & 2013 \\
\hline Caixa & $(3.930)$ & $(4.142)$ & $(4.173)$ & $(4.145)$ & $(4.174)$ & $(4.265)$ & $(4.359)$ \\
\hline Dívida BNDES & 7.000 & 14.026 & 20.961 & 26.509 & 30.669 & 26.443 & 20.804 \\
\hline Dívida de longo prazo operacional & 38.120 & 30.478 & 30.070 & 29.664 & 29.767 & 29.393 & 29.019 \\
\hline Dívida PESA & 16.195 & 16.195 & 16.195 & 16.195 & 16.195 & 16.195 & 16.195 \\
\hline Dívida Total sem PAES & 57.386 & 56.557 & 63.053 & 68.222 & 72.457 & 67.767 & 61.660 \\
\hline PAES & 46.227 & 42.154 & 37.685 & 32.820 & 28.055 & 22.927 & 17.435 \\
\hline Dívida Total com PAES & 103.612 & 98.711 & 100.738 & 101.042 & 100.513 & 90.694 & 79.094 \\
\hline Dívida em 31 Dezembro & 2014 & 2015 & 2016 & 2017 & 2018 & 2019 & 2020 \\
\hline Caixa & (4.359) & (4.359) & (4.359) & (4.359) & (4.359) & (4.359) & (4.359) \\
\hline Dívida BNDES & 13.869 & 8.322 & 4.161 & 1.387 & 0 & 0 & 0 \\
\hline Dívida de longo prazo operacional & 30.400 & 38.305 & 42.213 & 44.733 & 45.867 & 48.145 & 50.612 \\
\hline Dívida PESA & 16.195 & 16.195 & 16.195 & 16.195 & 16.195 & 16.195 & 16.195 \\
\hline Dívida Total sem PAES & 56.106 & 58.463 & 58.210 & 57.957 & 57.704 & 59.982 & 62.449 \\
\hline PAES & 13.287 & 10.629 & 7.803 & 4.808 & 1.645 & 0 & 0 \\
\hline Dívida Total com PAES & 69.393 & 69.092 & 66.013 & 62.765 & 59.349 & 59.982 & 62.449 \\
\hline
\end{tabular}

\subsection{Modelagem}

Quanto a aplicação do modelo de avaliação, aplicada a primeira abordagem de análise identificada neste estudo, a de análise qualitativa, identificando quais aspectos dos modelos empregados devem sofrer adaptações especificas para a indústria analisada, constituindo assim uma modelagem própria para esse setor. Neste ponto, foram identificados os value drivers específicos das empresas de álcool, através de critérios quantitativos sugeridos pelos autores que abordam tais modelos.

Em um segundo momento, foi aplicado o modelo de fluxo de caixa descontado como ferramenta de avaliação. Além disso, foi apresentado o descritivo de modelos de avaliação de opções e comentados alguns pontos importantes sobre os outros modelos de avaliação. Seguindo a análise, foi realizado um painel comparativo entre as diferentes relações na produção de álcool e açúcar.

O variável foco do trabalho para o cálculo do valor da empresa, pode-se identificada abaixo:

- As informações financeiras relativas à empresa que foram determinantes para a sua avaliação, tratadas neste trabalho como direcionadores do valor ou value drivers. A identificação destes direcionadores de valor foi feita conforme a sugestão da própria 
bibliografia levantada, identificando impactos financeiros relevantes e testando a sensibilidade dos componentes das taxas de juros praticadas;

- O método de avaliação de empresas e os requisitos para a sua aplicabilidade em casos diversos;

- As informações necessárias para a aplicação com sucesso das duas variáveis anteriores e acessibilidade a estas informações.

Com base nestas variáveis, desenvolveu-se uma análise qualitativa da aplicação, acessibilidade e utilidade de cada variável, objetivando obter um método ou um conjunto de métodos com diferentes graus de aplicabilidade e precisão. Não coube a este trabalho definir o grau de aplicabilidade dos modelos, mas sim desenvolver subsídios para obtê-lo através da análise qualitativa. Também não foi do escopo desta pesquisa definir um grau específico de precisão nos resultados obtidos para o modelo, mas o mesmo poderá ser estimado em função das limitações impostas pelos modelos mais simples o que foi auferido na análise quantitativa.

\subsubsection{Projeção dos dados da empresa}

A projeção dos resultados da empresa desenvolvida com base nas premissas expostas nos itens 5.2.1 a 5.2.4 é apresentada no Anexo 2. O uso da capacidade é de 100\% devido ao momento que o setor se encontra em franca expansão.

O estudo contempla a questão da perpetuidade do negócio após o período de 15 anos (2021) neste caso foi considerado para o cálculo do valor residual a capacidade produção constante do $14^{\circ}$ ano (2020).

No Anexo 2 estão os balanços patrimoniais projetados para a empresa, com base nos resultados obtidos e adotando as seguintes premissas:

- Prazo médio de recebimento das vendas é de 30 dias, com base no ano de 360 dias;

- A estrutura de capital irá variar de acordo com as premissas de endividamento;

- A totalidade dos lucros auferidos a cada exercício será distribuída; 
- O caixa operacional mantido na empresa será remunerado à taxa de juros de $9 \%$ ao ano;

- O imobilizado será consumido gradativamente logo na fase de inicio de operação pela depreciação projetada;

- A projeção do fluxo de caixa será considerada para os 15 anos de operação da usina, sendo considerada a perpetuidade constante para o cálculo do valor residual.

No Anexo 2 são projetados os fluxos de caixa anuais da empresa, considerando que a empresa distribui aos seus sócios parte do valor integral correspondente ao lucro de cada exercício, em razão de haver necessidade de investimentos para manutenção dos equipamentos e instalações.

\subsubsection{Taxa de desconto para ofluxo de caixa livre para o acionista.}

O modelo utilizado para a taxa de desconto apropriada para avaliar o custo de oportunidade do capital empregado para gerar o caixa livre para os acionistas é o CAPM, para isso será necessária a estimativa da taxa livre de risco do mercado, do risco sistemático da empresa (Beta) e do prêmio médio esperado para o mercado brasileiro.

A taxa livre de risco para o mercado brasileiro é estimada considerando a taxa de juros americana e estimando alguns cenários possíveis. Além disso, foram considerados 2 momentos para o desconto, sendo que a taxa 1 refere-se ao momento atual e a taxa 2 daqui a 3 anos (adotando um viés conservador).A principal agencia de risco S\&P acredita que mantendo a conjuntura atual o Brasil, o país entrará no grau de investimento, ou seja, país com graus de risco baixo em condições de receber investimentos dos grandes fundos internacionais.

\begin{tabular}{|l|}
\hline \multicolumn{1}{|c|}{ Item } \\
\hline Risco País (bp) \\
Juros Títulos Brasileiros Exterior \\
Juros Americanos \\
Selic \\
IPCA \\
Juros Reais \\
\hline
\end{tabular}

\begin{tabular}{|c|c|}
\hline Taxa 1 & Taxa 2 \\
\hline 150 & 90 \\
$8,50 \%$ & $7,90 \%$ \\
$4,85 \%$ & $4,85 \%$ \\
$12,00 \%$ & $10,00 \%$ \\
$2,50 \%$ & $2,50 \%$ \\
$9,27 \%$ & $7,32 \%$ \\
\hline
\end{tabular}

Tabela 33 - Tabela de juros. 
Quanto a um eventual cenário inflacionário, não há necessidade de computar-se a título de previsão, a taxa de inflação, uma vez que os valores são projetados em moeda constante. Isto se explica facilmente, pois o valor atual, por definição, é dado pelo valor da moeda no momento em que o investimento é realizado. Os fluxos de caixa livre também são apurados no instante de sua formação. Se atualizarmos esses fluxos com uma taxa de inflação projeta, teremos que descontar desses fluxos às mesmas taxas, para obter seu valor presente. Assim, este método permite ignorar a inflação, já que a análise é feita em moeda constante. Portanto, não haveria qualquer modificação no cálculo do valor presente caso inflacionássemos os valores antes e os deflacionássemos depois.

\subsubsection{Cálculo do beta}

A falta de empresas deste setor em especial no Brasil, onde é o foco de estudo, forçará a busca de outras empresas em setores similares. Neste caso, o setor mais próximo que também faz parte dos bicombustíveis é o álcool.

O beta foi calculado buscando empresas no exterior no setor de etanol, sendo consideradas as premissas de perfil semelhantes e compatibilidade de risco de negócios e alavancagem financeira. $\mathrm{O}$ beta médio do setor foi adotado como beta previsto para a empresa avaliada.

Através de pesquisa ao sistema Bloomberg (2007), foi feito um levantamento das informações de mercado do setor de álcool, utilizando como parâmetros: a data referência em dezembro de 2006, prazo histórico para a análise estatística de 24 meses, dados em moedas locais de cada país. Os detalhes estão no Anexo 2.

\section{Beta Beta Desalavancado}

\begin{tabular}{lcc}
\hline Média & 0,78 & 0,56 \\
\hline Mediana & 0,78 & 0,56 \\
\hline Desvio Padrão & 0,24 & 0,21 \\
\hline
\end{tabular}

Tabela 34 - Cálculo do Beta.

Fonte: Produzido pelo Autor 
A média dos valores calculados indica um Beta de 0,56 , que foi o valor adotado como referencia do risco sistemático para o cálculo do custo de capital próprio da empresa analisada, apresentado no próximo item.

\subsubsection{Aplicação do CAPM}

A análise dos resultados obtidos mostra um beta médio de 0,56 para as empresas brasileiras do setor de biocombustíveis. A partir do beta estimado, foram reunidos os elementos necessários à aplicação do Capital Asset Pricing Model - CAPM para determinar o custo de capital próprio. Portanto, fez-se necessário definir os parâmetros componentes do modelo, a saber:

c) Taxa livre e risco do mercado brasileiro: adotou-se para a taxa de risco a Taxa de Juros em 2 momentos distintos como discutido num dos itens acima neste capítulo. Para o momento 1 (primeiros 3 anos) a taxa de 12,50\% e no momento 2 (após os primeiros 3 anos) a taxa de $10,00 \%$.

d) Taxa de retorno do mercado brasileiro: adotou-se a taxa de retorno do Índice Bovespa para uma série de 10 anos capitalizada pelo método contínuo. A seleção deste intervalo deve-se ao fato de o mesmo representar o único período da história recente do Brasil em que a economia pós Plano Real desenvolveu de forma globalizada. Nos últimos 5 anos, houve um crescimento significativo no mercado acionário brasileiro com a entrada de novas empresas na bolsa, aumento do número de investidores e mudança de foco quanto ao nível de especulação. Este período pode ser dividido em 2 etapas:

a. Fase 1 - Momento de expansão especulativo: parte dos recursos investidos em bolsa apresentava riscos maiores que os atuais pelo simples fato do país entrar em períodos de turbulências e vulnerabilidade e maior participação de grandes players.

b. Fase 2 - Momento de expansão na forma de investimento: a entrada do grande público no mercado acionário brasileiro, apresentando momentos do crescimento de abertura do capital de novas empresas, associado ao fato do Brasil alcançar recentemente maior estabilidade econômica. 
Prêmio de risco nos mercados acionários: conforme DAMODARAN (1997) há três fundamentos que determinam o prêmio pelo risco nos mercados acionários dos diferentes países: instabilidade econômica, risco político e estrutura de mercado. O premio pelo risco é calculado pela diferença do retorno médio de mercado e a taxa livre de risco adotada.

\begin{tabular}{|l|c|c|c|}
\hline \multicolumn{1}{|c|}{ Componente } & Taxa 1 & Taxa 2 & Descrição \\
\hline $\begin{array}{l}\text { Taxa livre de Risco } \\
\text { Brasileira }\left(r_{\mathrm{f}}\right)\end{array}$ & $12,50 \%$ & $10,00 \%$ & Taxa Juros Projetada \\
\hline $\begin{array}{l}\text { Retorno do Mercado } \\
\text { Brasileiro }\left(r_{\mathrm{m}}\right)\end{array}$ & $10,25 \%$ & $10,25 \%$ & $\begin{array}{c}\text { Retorno médio anual do índice } \\
\text { BOVESPA de 1996-2006 }\end{array}$ \\
\hline $\begin{array}{l}\text { Prêmio pelo Risco de } \\
\text { Mercado }\end{array}$ & $-2,25 \%$ & $0,25 \%$ & $\begin{array}{c}\text { Prêmio pelo risco (spread) entre o } \\
\text { retorno livre de risco e o retorno de } \\
\text { mercado }\end{array}$ \\
\hline
\end{tabular}

Tabela 35 - Aplicação do CAPM - Taxas ao ano

Fonte: Produzido pelo Autor

Na tabela acima o prêmio de risco é inferior à desejada pelos investidores, que de acordo com COOPERS \& LYBRAND apud CASTRO (2000) deve ser de 4\%. Neste caso, como o mercado está em fase de maturação quando comparado ao passado optou-se em trabalhar como o prêmio de risco de 4\%. Portanto, o retorno médio esperado para o mercado e a taxa livre de risco mais a estimativa de premio de risco de 4\%, resultando em um retorno médio esperado de mercado de $14,74 \%$ no instante 1 e $12,24 \%$ no instante 2 .

Partindo destas premissas adotadas, podemos determinar o custo de capital próprio para as empresas do setor de biocombustíveis aplicando a Equação:

$$
K_{e}=r_{f}+\beta\left(E\left[r_{m}\right]-r_{f}\right)
$$

Que nos fornece o seguinte resultado:

$$
\begin{aligned}
& \mathrm{K}_{\mathrm{e}, 1}=14,74 \% \text { ao ano no período } 1 ; \\
& \mathrm{K}_{\mathrm{e}, 2}=12,24 \% \text { ao ano no período } 2 .
\end{aligned}
$$




\subsubsection{Cálculo do Custo Médio Ponderado de Capital - WACC}

Conforme exposto no Capítulo 2, alternativamente à valoração da empresa pelo desconto do fluxo de caixa para o acionista, pode-se atingir o mesmo objetivo descontando o fluxo de caixa para a empresa com uma taxa de desconto diferenciada, obtida pelo custo médio ponderado de capital - WACC. Esta nova taxa deve refletir a remuneração esperada pelo capital total empregado na empresa, incluindo o capital de terceiros (representado pelo passivo da empresa). A suposição feita em relação à estrutura da dívida da empresa foi a de que todo o capital de terceiro da empresa seria refinanciado a uma taxa igual àquela praticada no financiamento original. Ao se optar pela análise dos fluxos de caixa para a empresa, a taxa de desconto utilizada foi o WACC e, neste caso, mudanças na composição da divida com diferentes taxas de juros resultaram em um WACC variável, exigindo que os fluxos de caixa fossem descontados a taxas diferentes a cada período. O conceito de WACC variável aplicase aos primeiros anos de atividade da usina, pois foram adotadas diferentes taxas ao longo da vida da empresa.

Conforme proposto no Capítulo 2, defini-se o WACC como o custo ponderado entre o custo de capital próprio e custo de capital de terceiros. Para o custo de capital de terceiros, adotouse as taxas de juros dos financiamentos realizados com o BNDES, livres de inflação, e descontou-se das mesmas o imposto de renda e a contribuição social ( $9 \%$ no total). Assim, foi obtida a estrutura de taxas de juros mostrada na tabela.

\begin{tabular}{|l|c|c|c|}
\hline \multicolumn{1}{|c|}{ Componente } & Taxa 1 & Taxa 2 & Descrição \\
\hline Taxa do financiamento TJLP & $7,50 \%$ & $5,92 \%$ & Taxa Juros Projetada \\
\hline Selic & $12,50 \%$ & $10,00 \%$ & Taxa cobrada pelo banco para repasse \\
\hline Taxa da Dívida de Curto Prazo & $12,00 \%$ & $10,10 \%$ & Taxa efetiva de Financiamento \\
\hline Taxa da Dívida de Longo Prazo & $9,30 \%$ & $8,20 \%$ & Taxa efetiva de Financiamento \\
\hline Taxa Ponderada Média da Dívida & $10,30 \%$ & $8,90 \%$ & Taxa efetiva de Financiamento \\
\hline
\end{tabular}

Tabela 36 - Taxa de Financiamento.

Fonte: Produzido pelo Autor 
Partindo destas premissas adotadas, podemos determinar o custo de capital próprio para as empresas do setor de biodiesel aplicando a Equação:

$$
K_{d}=i^{*}(1-I R)
$$

Que nos fornece o seguinte resultado:

$$
\begin{aligned}
& \mathrm{K}_{\mathrm{d}, 1}=8,03 \% \text { ao ano no período } 1 ; \\
& \mathrm{K}_{\mathrm{d}, 2}=6,94 \% \text { ao ano no período } 2 \text {. }
\end{aligned}
$$

\begin{tabular}{|c|c|c|c|c|c|c|c|}
\hline & 2007 & 2008 & 2009 & 2010 & 2011 & 2012 & 2013 \\
\hline Estrutura Capital & $100 \%$ & $100 \%$ & $100 \%$ & $100 \%$ & $100 \%$ & $100 \%$ & $100 \%$ \\
\hline Própria & $41 \%$ & $46 \%$ & $47 \%$ & $49 \%$ & $50 \%$ & $55 \%$ & $58 \%$ \\
\hline Terceiros & $59 \%$ & $54 \%$ & $53 \%$ & $51 \%$ & $50 \%$ & $45 \%$ & $42 \%$ \\
\hline \multicolumn{8}{|l|}{ Custo do Capital Próprio } \\
\hline Taxa Livre de Risco & $12,50 \%$ & $11,67 \%$ & $10,83 \%$ & $10,00 \%$ & $10,00 \%$ & $10,00 \%$ & $10,00 \%$ \\
\hline Risco de Mercado & $4,00 \%$ & $4,00 \%$ & $4,00 \%$ & $4,00 \%$ & $4,00 \%$ & $4,00 \%$ & $4,00 \%$ \\
\hline Beta & 0,56 & 0,56 & 0,56 & 0,56 & 0,56 & 0,56 & 0,56 \\
\hline $\mathrm{Ke}$ & $14,74 \%$ & $13,91 \%$ & $13,07 \%$ & $12,24 \%$ & $12,24 \%$ & $12,24 \%$ & $12,24 \%$ \\
\hline \multicolumn{8}{|c|}{ Custo do Capital de Terceiros } \\
\hline TJLP & $10,30 \%$ & $9,61 \%$ & $8,93 \%$ & $8,90 \%$ & $8,90 \%$ & $8,90 \%$ & $8,90 \%$ \\
\hline Spread bancário & $0,00 \%$ & $0,00 \%$ & $0,00 \%$ & $0,00 \%$ & $0,00 \%$ & $0,00 \%$ & $0,00 \%$ \\
\hline IR+ Contribuição Social & $22,00 \%$ & $22,00 \%$ & $22,00 \%$ & $22,00 \%$ & $22,00 \%$ & $22,00 \%$ & $22,00 \%$ \\
\hline Kd & $8,03 \%$ & $7,50 \%$ & $6,96 \%$ & $6,94 \%$ & $6,94 \%$ & $6,94 \%$ & $6,94 \%$ \\
\hline \multirow[t]{2}{*}{ WACC } & $10,79 \%$ & $10,47 \%$ & $9,85 \%$ & $9,52 \%$ & $9,58 \%$ & $9,83 \%$ & $10,00 \%$ \\
\hline & 2014 & 2015 & 2016 & 2017 & 2018 & 2019 & 2020 \\
\hline Estrutura Capital & $100 \%$ & $100 \%$ & $100 \%$ & $100 \%$ & $100 \%$ & $100 \%$ & $100 \%$ \\
\hline Própria & $60 \%$ & $59 \%$ & $60 \%$ & $61 \%$ & $62 \%$ & $62 \%$ & $60 \%$ \\
\hline Terceiros & $40 \%$ & $41 \%$ & $40 \%$ & $39 \%$ & $38 \%$ & $38 \%$ & $40 \%$ \\
\hline \multicolumn{8}{|l|}{ Custo do Capital Próprio } \\
\hline Taxa Livre de Risco & $10,00 \%$ & $10,00 \%$ & $10,00 \%$ & $10,00 \%$ & $10,00 \%$ & $10,00 \%$ & $10,00 \%$ \\
\hline Risco de Mercado & $4,00 \%$ & $4,00 \%$ & $4,00 \%$ & $4,00 \%$ & $4,00 \%$ & $4,00 \%$ & $4,00 \%$ \\
\hline Beta & 0,56 & 0,56 & 0,56 & 0,56 & 0,56 & 0,56 & 0,56 \\
\hline $\mathrm{Ke}$ & $12,24 \%$ & $12,24 \%$ & $12,24 \%$ & $12,24 \%$ & $12,24 \%$ & $12,24 \%$ & $12,24 \%$ \\
\hline \multicolumn{8}{|c|}{ Custo do Capital de Terceiros } \\
\hline Taxa Média Ponderada & $8,90 \%$ & $8,90 \%$ & $8,90 \%$ & $8,90 \%$ & $8,90 \%$ & $8,90 \%$ & $8,90 \%$ \\
\hline Spread bancário & $0,00 \%$ & $0,00 \%$ & $0,00 \%$ & $0,00 \%$ & $0,00 \%$ & $0,00 \%$ & $0,00 \%$ \\
\hline IR+ Contribuição Social & $22,00 \%$ & $22,00 \%$ & $22,00 \%$ & $22,00 \%$ & $22,00 \%$ & $22,00 \%$ & $22,00 \%$ \\
\hline Kd & $6,94 \%$ & $6,94 \%$ & $6,94 \%$ & $6,94 \%$ & $6,94 \%$ & $6,94 \%$ & $6,94 \%$ \\
\hline WACC & $10,14 \%$ & $10,08 \%$ & $10,11 \%$ & $10,18 \%$ & $10,24 \%$ & $10,21 \%$ & $10,14 \%$ \\
\hline
\end{tabular}

Aplicando a formulação para o cálculo do WACC de acordo com a equação descrita no Capítulo 2, temos a estrutura temporal da taxa de desconto apresentada na Tabela.

Tabela 37 - Cálculo do WACC.

Fonte: Produzido pelo Autor 
O WACC para o ano 2007 deve ser considerado integral, pois o estudo parte do princípio que o valor da empresa será calculado com base no fechamento do balanço em dezembro de 2006, desta data em diante os dados serão projeções baseadas nos resultados e modelo de negócio. A estrutura temporal de WACC's variáveis apresentada na tabela foi então utilizada para desconto dos fluxos de caixa para a empresa, para obtenção de uma estimativa de valor para a empresa.

\subsection{Aplicação do método de avaliação ao caso base}

Conforme as premissas e parametrizações identificadas no inicio deste capítulo, procederamse à projeção dos resultados, balanços patrimoniais e fluxos de caixa para o acionista. Estas projeções encontram-se no Anexo 2. Toda a estimativa de valor da empresa foi baseada em seus fluxos de caixa e no valor residual.

\subsubsection{Fluxo de caixa para o acionista}

O fluxo de caixa apresentado no Anexo 2 corresponde ao fluxo de caixa líquido para os acionistas. Todo o fluxo de caixa foi descontado a uma taxa variável pelo CAPM apresentados no item 5.3.2.2. O valor presente do fluxo acumulado e a evolução dos mesmos são apresentados na tabela. Lembrando que a partir de 2020, o valor da empresa é baseado na perpetuidade com crescimento de fluxo zero. 


\begin{tabular}{|c|c|c|c|}
\hline & \multicolumn{2}{|c|}{ Taxa Desconto } \\
\hline Ano & \begin{tabular}{|c|}
$\begin{array}{c}\text { Fluxo de Caixa } \\
\mathbf{R} \$ \mathrm{mil}\end{array}$ \\
\end{tabular} & Ke & $\begin{array}{l}\text { VP Fluxo Caixa } \\
\text { R\$ mil }\end{array}$ \\
\hline 2007 & 40.895 & $14,74 \%$ & 35.641 \\
\hline 2008 & 22.966 & $13,91 \%$ & 53.342 \\
\hline 2009 & 25.115 & $13,07 \%$ & 70.714 \\
\hline 2010 & 18.353 & $12,24 \%$ & 82.278 \\
\hline 2011 & 12.850 & $12,24 \%$ & 89.492 \\
\hline 2012 & -3.087 & $12,24 \%$ & 87.948 \\
\hline 2013 & 4.376 & $12,24 \%$ & 89.898 \\
\hline 2014 & 7.308 & $12,24 \%$ & 92.799 \\
\hline 2015 & 18.526 & $12,24 \%$ & 99.352 \\
\hline 2016 & 18.870 & $12,24 \%$ & 105.299 \\
\hline 2017 & 23.021 & $12,24 \%$ & 111.763 \\
\hline 2018 & 22.886 & $12,24 \%$ & 117.489 \\
\hline 2019 & 27.668 & $12,24 \%$ & 123.656 \\
\hline 2020 & 30.206 & $12,24 \%$ & 129.654 \\
\hline \multirow[t]{2}{*}{$>2020$} & 30.206 & $12,24 \%$ & 176.542 \\
\hline & & & $\mathrm{R} \$ \mathrm{mil}$ \\
\hline \multicolumn{3}{|c|}{$\begin{array}{l}\text { Total Fluxo Caixa Projetado } \\
\text { Total Resíduo Projetado }\end{array}$} & $\begin{array}{c}129.654 \\
46.888\end{array}$ \\
\hline \multicolumn{3}{|c|}{ Total Valor para Acionista } & 176.542 \\
\hline & & & $(\%)$ \\
\hline \multicolumn{3}{|c|}{$\begin{array}{l}\text { Total Fluxo Caixa Projetado } \\
\text { Total Resíduo Projetado } \\
\end{array}$} & $\begin{array}{l}73,4 \% \\
26,6 \%\end{array}$ \\
\hline \multicolumn{3}{|c|}{ Total Valor para Acionista } & $100,0 \%$ \\
\hline
\end{tabular}

Tabela 38 - Valore presente do fluxo de caixa para acionista. Fonte: Produzido pelo Autor

Observa-se que o horizonte proposto para o cálculo do fluxo de caixa, permitiu gerar resultados satisfatórios na relação do valor total dos fluxos de caixa projetados e o valor total para o acionista $(69,6 \%)$. Para o acionista considerando todas as premissas propostas, chegase ao valor de R\$176.542 mil.

\subsubsection{Fluxo de caixa para a empresa}

Procedeu-se aos ajustes necessários ao fluxo de caixa para obter os fluxos de caixa para a empresa, os quais foram descontados a valor presente pela estrutura temporal dos WACC's apresentada na tabela. Para tanto, desenvolveu-se a projeção da taxa de desconto para desconto de cada fluxo de caixa. As projeções da taxa de desconto acumulada, dos ajustes 
para compor os fluxos de caixa para a empresa do valor presente de cada fluxo e do valor presente total acumulado do fluxo de caixa são apresentados na tabela.

\begin{tabular}{|c|c|c|c|}
\hline & & & a Calculada \\
\hline Ano & \begin{tabular}{|c|} 
Fluxo de Caixa \\
R\$ mil
\end{tabular} & WACC & $\begin{array}{c}\text { VP Fluxo Caixa } \\
\text { R\$ mil }\end{array}$ \\
\hline 2007 & 49.751 & $10,79 \%$ & 44.905 \\
\hline 2008 & 27.622 & $10,47 \%$ & 67.539 \\
\hline 2009 & 21.698 & $9,85 \%$ & 83.906 \\
\hline 2010 & 16.032 & $9,52 \%$ & 95.050 \\
\hline 2011 & 11.151 & $9,58 \%$ & 102.106 \\
\hline 2012 & 3.740 & $9,83 \%$ & 104.237 \\
\hline 2013 & 11.864 & $10,00 \%$ & 110.325 \\
\hline 2014 & 13.672 & $10,14 \%$ & 116.637 \\
\hline 2015 & 16.829 & $10,08 \%$ & 123.730 \\
\hline 2016 & 19.392 & $10,11 \%$ & 131.135 \\
\hline 2017 & 23.032 & $10,18 \%$ & 139.060 \\
\hline 2018 & 22.086 & $10,24 \%$ & 145.916 \\
\hline 2019 & 23.605 & $10,21 \%$ & 152.587 \\
\hline 2020 & 25.250 & $10,14 \%$ & 159.115 \\
\hline$>2020$ & 25.250 & $10,14 \%$ & 223.978 \\
\hline & & & $\mathrm{R} \$ \mathrm{mil}$ \\
\hline Total Flu & o Caixa Projetac & & 159.115 \\
\hline Total Re & duo Projetado & & 64.863 \\
\hline Total Val & r Empresa & & 223.978 \\
\hline
\end{tabular}

(-) Dívida

(62.449)

Valor Acionista (Met. Empresa) 161.529

\begin{tabular}{|lc|}
\hline Valor Acionista & 176.542 \\
\hline Diferença (\%) & $-8,5 \%$ \\
\hline
\end{tabular}

\begin{tabular}{|lc|}
\cline { 2 - 2 } \multicolumn{1}{c|}{} & $(\%)$ \\
\hline Total Fluxo Caixa Projetado & $71,0 \%$ \\
Total Resíduo Projetado & $29,0 \%$ \\
\hline \hline Total Valor Empresa & $100,0 \%$ \\
\hline
\end{tabular}

Tabela 39 - Valore presente do fluxo de caixa para empresa Fonte: Produzido pelo Autor

$\mathrm{Na}$ tabela abaixo o fluxo de caixa projetado comparado com o fluxo de caixa total chegou a uma relação satisfatória de $71,0 \%$. Para o cálculo do valor do acionista baseado no valor da empresa, subtraímos alguns componentes do valor da empresa, como segue na tabela. 


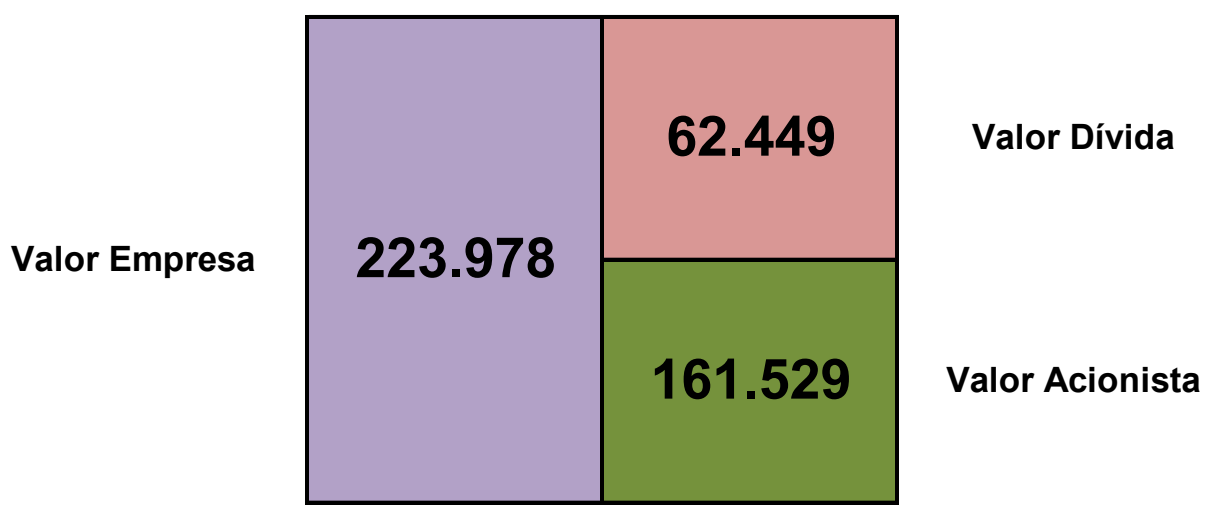

Tabela 40 - Diagrama de composição de valores (em R \$ mil)

Fonte: Produzido pelo Autor

Comparando os valores dos acionistas pelos métodos descritos nos itens 5.4.1 e 5.4.2, verificamos uma diferença de $0,2 \%$, ou seja,

\subsubsection{Resultados e Análise de Sensibilidade}

Na avaliação da Usina não levou em consideração o possível ponto de vista de um comprador especial, que por motivos estratégicos, de economias de escala, sinergias ou outros, poderiam pagar um prêmio para adquirir as ações da Empresa. Igualmente não foi considerado qualquer desconto que eventualmente poderia ser aplicável a participações minoritárias, já que o trabalho refere-se a 100\% das ações da Empresa. Da mesma forma, o trabalho não considera qualquer desconto por falta de liquidez eventualmente aplicável a empresas sem ações negociadas em bolsa de valores.

A taxa de desconto é utilizada para descontar os fluxos de caixa futuro da empresa e também indica retorno esperado pelo investidor. No Capítulo 2 ficou evidente a dificuldade em se calcular com precisão o custo de capital próprio de uma empresa brasileira, dada a escassez de informações e a rentabilidade atípica das empresas listadas em bolsa de valores durante a década de 90. Em razão desta dificuldade, torna-se bastante útil uma análise da sensibilidade do valor obtido para a empresa faze a variação na taxa de desconto.

A partir das premissas preparadas pela administração da Usina, as seguintes análises de sensibilidade foram desenvolvidas: 
$\underline{\text { Sensibilidade } 1}$

Foi considerado o aumento de preço em $+-25 \%$ para o açúcar e álcool.

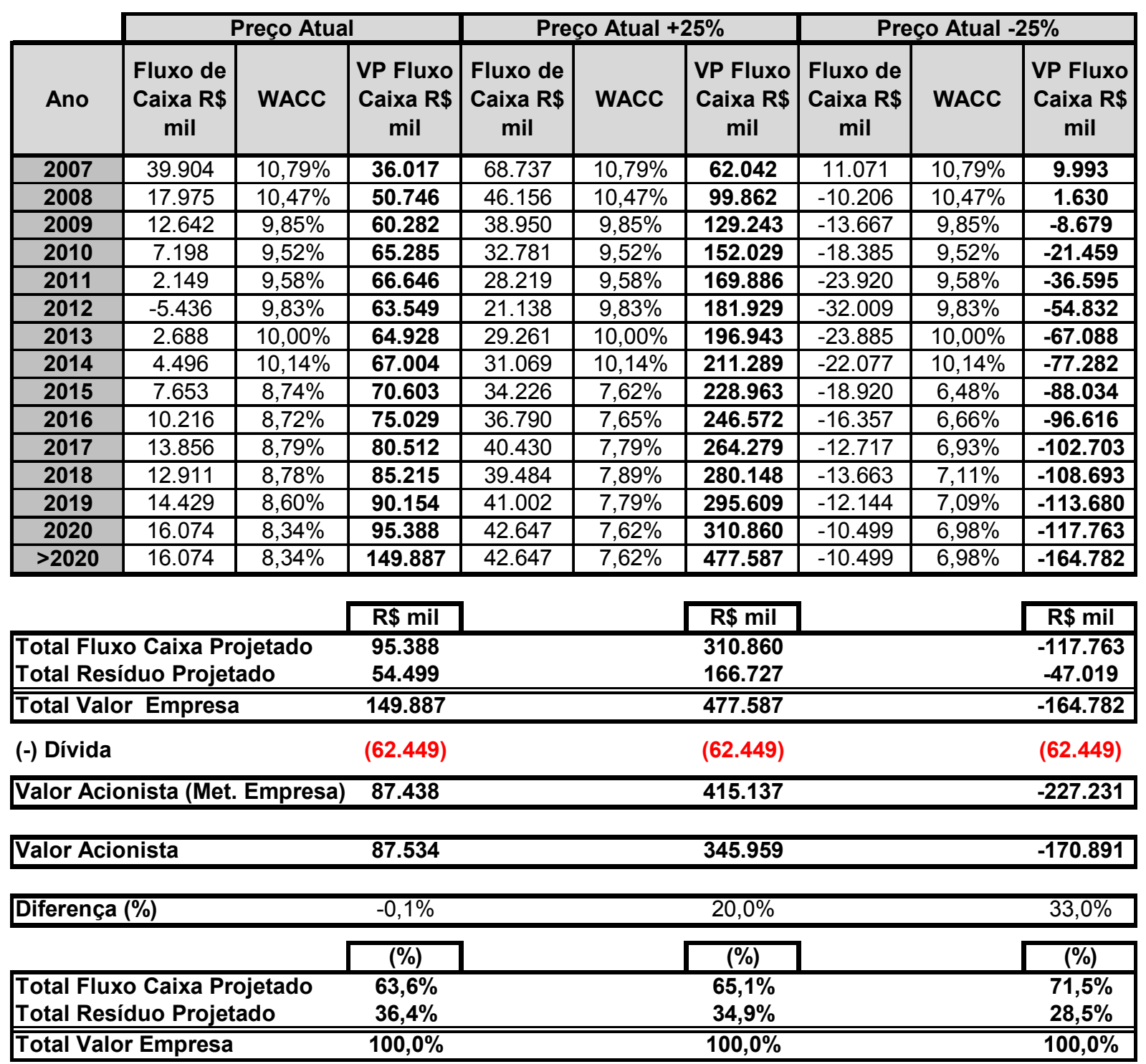

Tabela 41 - Simulação da variação de preço.

Fonte: Produzido pelo Autor

\section{Sensibilidade 2}

Como o custo de capital de terceiros - o custo dos juros das dívidas - é perfeitamente identificado em relações contratuais, o único componente que pode gerar incerteza na composição do custo de capital é o custo de capital próprio. Assim, precedeu-se a uma análise dos valores que seria obtido para diferentes possibilidades de custo de capital próprio, estimadas em variações iguais à mais ou menos 2 pontos percentuais, todas elas acima do mais algo custo da dívida. 


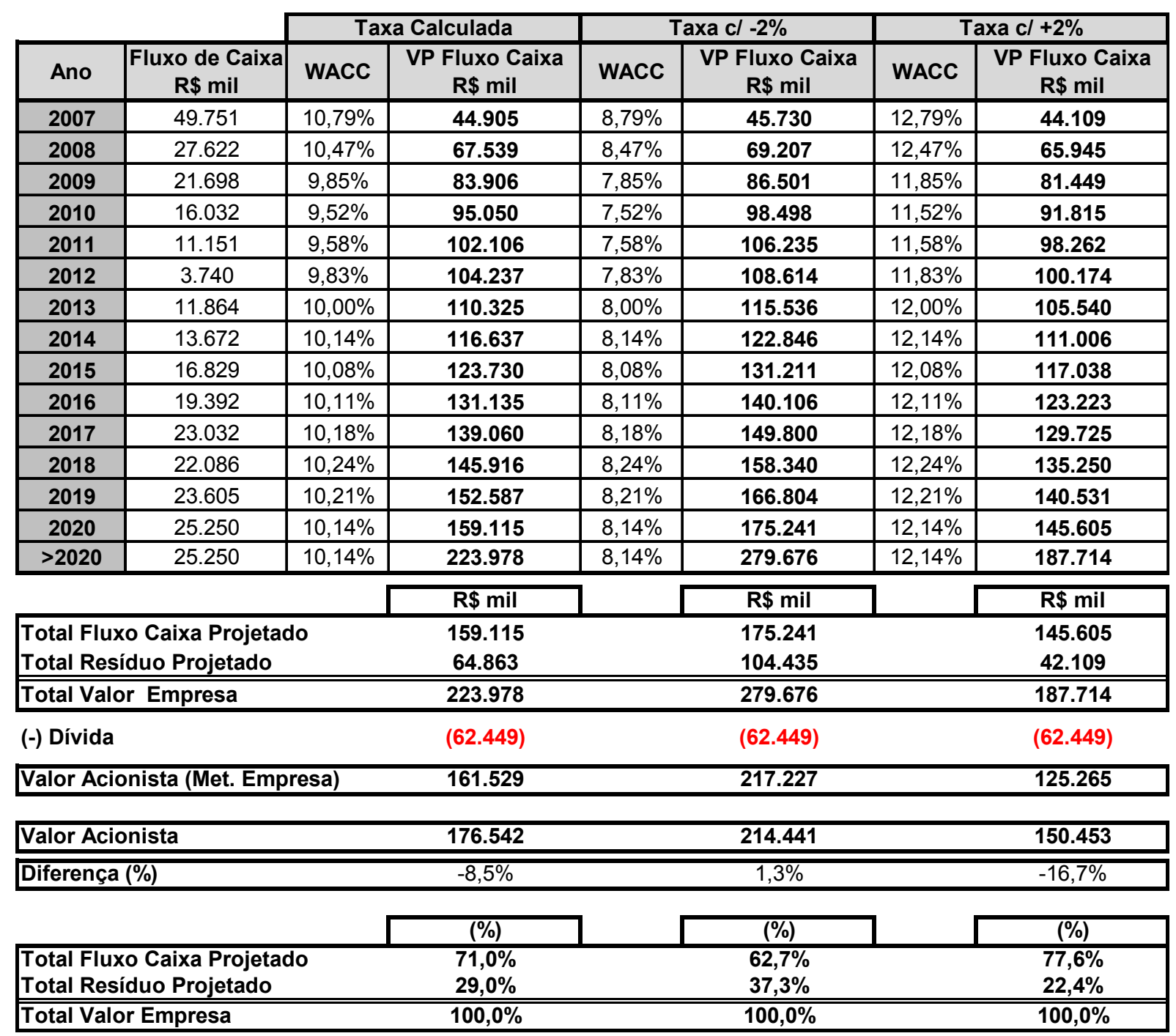

Tabela 42 - Simulação de variação da taxa.

Fonte: Produzido pelo Autor

\section{$\underline{\text { Sensibilidade } 3}$}

Considerando mudanças no mix de produção:

\begin{tabular}{|lcccc|}
\cline { 2 - 5 } \multicolumn{1}{c|}{$(\%)$ Álcool } & $100 \%$ & $80 \%$ & $60 \%$ & $40 \%$ \\
\hline Total Fluxo Caixa Projetado & 318.005 & 243.977 & 169.863 & 95.388 \\
Total Resíduo Projetado & 170.652 & 132.699 & 94.357 & 54.499 \\
\hline \hline Total Valor Empresa & 488.657 & 376.676 & 264.220 & 149.887 \\
\hline & & & & \\
\hline (-) Dívida & $(62.449)$ & $(62.449)$ & $(62.449)$ & $(62.449)$ \\
\hline Valor Acionista (Met. Empresa) & 426.208 & 314.226 & 201.771 & 87.438 \\
\hline
\end{tabular}

Tabela 43 - Variação Mix

Fonte: Produzido pelo Autor 
A tabela apresenta as estimativas de valores finais obtidos para a empresa, segundo cada um das proporções empregadas.

O emprego do método do Valor Presente dos Fluxos de Caixa Projetados mostrou-se satisfatória como ferramenta de valoração da empresa em razão da diversidade de parâmetros considerados e do pleno cumprimento das limitações observadas nos métodos descritos no Capítulo 2. Simplificações no timing de caixa da empresa, embutidas nas projeções dos fluxos de caixa, levaram a diferenças nas estimativas de valor obtidas a partir dos fluxos de caixa para a empresa e para o acionista.

O modelo de fluxos de caixa pode ser tratado como variáveis aleatórias, mas não iremos encontrar diferença entre a valoração média deste método e o valor determinístico da forma simplificada. A razão para isso é a significativa previsibilidade do fluxo de caixa para este tipo de empresa, limitando a componentes pouco significativos do caixa a incerteza para a variabilidade no fluxo. Observa-se, portanto, que o emprego da técnica de projeção supondo o fluxo de caixa como variável aleatória apenas tem a contribuir com a percepção da variabilidade dos possíveis valores. A limitação deste método está na dificuldade em se desenvolver um modelo consistente para a estimativa do custo de capital próprio da empresa, dada a ineficiência das ações das empresas do setor no mercado de capitais.

\subsubsection{Múltiplos setoriais}

O objetivo deste item do trabalho é simular o valor da empresa nas diferentes regiões do Brasil, com diferentes índices de produtividade média.

O preço médio encontrado na tabela será considerado no modelo proposto no item anterior, sofrendo algumas modificações como: custo de produção do álcool, preço médio de acordo com a UNICA. O modelo proposto será mantido:

- Estruturas de capital: o valor a ser financiado será o mesmo em todas as regiões;

- Investimento: a tecnologia empregada é a mesma, difere o valor da terra, mas não foi considerada esta diferença no modelo, todos os insumos se aplicam a mesma tecnologia;

- Índice de produtividade: foi considerado o mesmo para todas as regiões; 
- Custos Fixos, Despesas, Depreciação: todos estes dados são mantidos, pois diferem pouco e não de forma significativa.

- Foram calculados 14 anos de projeção do fluxo de caixa e valor residual com fluxo constante a partir de 2021.

$\mathrm{Na}$ tabela encontram-se o resultado do relatório da ÚNICA sobre os valores médios de produtividade nas diferentes regiões do Brasil. Mantendo as mesmas premissas para todos os cálculos.

\begin{tabular}{|c|c|c|c|c|c|}
\hline \multirow[b]{2}{*}{ Região } & \multirow[b]{2}{*}{ ton cana/há } & \multirow[b]{2}{*}{ ton cana } & \multicolumn{2}{|c|}{$\mathrm{R} \$ \mathrm{mil}$} & \multirow[b]{2}{*}{$\mathrm{R} \$$ /ton } \\
\hline & & & Empresa & Acionista & \\
\hline Norte & 64,98 & 1.378 .684 & (93.849) & (156.295) & $(113)$ \\
\hline Nordeste & 52,98 & 1.209 .718 & (206.728) & (269.177) & (223) \\
\hline Sudeste & 77,68 & 1.557 .506 & 45.482 & (16.968) & (11) \\
\hline Sul & 71,80 & 1.523 .299 & (27.139) & (89.588) & (59) \\
\hline Centro-Oeste & 71,12 & 1.508 .872 & (34.036) & (96.486) & (64) \\
\hline
\end{tabular}

Tabela 44 - Resultado do valor da empresa por região.

Fonte: Produzido pelo Autor

$\mathrm{Na}$ tabela, foram calculados os valores para cada região para uma mudança de mix de $60 \%$ álcool.

\begin{tabular}{|c|c|c|c|c|c|}
\hline \multirow[b]{2}{*}{ Região } & \multirow[b]{2}{*}{ ton cana/há } & \multirow[b]{2}{*}{ ton cana } & \multicolumn{2}{|c|}{$\mathrm{R} \$ \mathrm{mil}$} & \multirow[b]{2}{*}{$\mathrm{R} \$$ /ton } \\
\hline & & & Empresa & Acionista & \\
\hline Norte & 64,98 & 1.378 .684 & (8.501) & (70.951) & (51) \\
\hline Nordeste & 52,98 & 1.209 .718 & (107.705) & (170.154) & (141) \\
\hline Sudeste & 77,68 & 1.557 .506 & 100.054 & 37.605 & 24 \\
\hline Sul & 71,80 & 1.523 .299 & 50.954 & $(11.495)$ & (8) \\
\hline Centro-Oeste & 71,12 & 1.508 .872 & 45.943 & (16.506) & (11) \\
\hline
\end{tabular}

Tabela 45 - Comparativo entre diferentes regiões.

Fonte: Produzido pelo Autor

A produtividade média no Sudeste garante um valor positivo para o valor da empresa, enquanto nos outros estados não é interessante este tipo de negócio. 
Portanto, esta tabela serve de referencial para o cálculo do valor da empresa apresentando as seguintes variáveis no modelo: fonte de matéria-prima, região geográfica, estrutura de capital e preço de contrato.

\subsection{Avaliação pela Teoria das Opções}

Segundo o preceito de COPELAND ET AL (1994) de que a identificação de uma atividade empresarial para a aplicação da Teoria de Opções Reais pressupõe flexibilidade, constata-se que empresas com características como as de uma usina de açúcar e álcool restringem a possibilidade do emprego deste método de avaliação, dada a rígida inflexibilidade do modelo empresarial identificado neste tipo de empresa.

A demanda garantida para os próximos anos e os contratos de fornecimento para a Petrobras eliminam riscos específicos do negócio, garantindo significativamente previsibilidade nos resultados. Cada uma das formas de opções empresarial definidas por COPELAND ET AL. (1994) pode ser refutada. A opção de adiar o investimento praticamente inexiste, dado que o cronograma de montagem da usina é curto e necessita de um projeto final para iniciar a produção. A opção de expandir não foi considerada no modelo, pois em razão da natureza da usina, viabiliza a construção de uma nova usina para melhor aproveitar a logística de transporte. A opção de contratar ou de alternância de produção não se aplica, já que o setor irá passar por uma expansão e um mercado garantido, inviabilizando a escolha de não produção dado a característica do negócio e o intensivo investimento em equipamentos. O único tipo de opção aplicável a usina - a de abandonar - é inviável.

Assim, a impossibilidade de identificação de flexibilidade na forma de opções da empresa desqualifica o método de avaliação pela Teoria de Opções Reais como uma alternativa à estimativa do valor de negociação da empresa.

\subsection{Avaliação de empresa pelo Valor Contábil}

A avaliação pelo método do Valor Contábil definida por CORNELL (1994) propõe a estimativa de um valor supondo que o novo detentor das ações ordinárias da empresa deva liquidar os compromissos totais assumidos pelos antigos detentores. Em outras palavras, não 
supõe a continuidade das dívidas, propiciando assim um valor significativamente mais elevado. Como no setor de biocombustíveis é comum o elevado nível de endividamento das empresas, tal consideração tende a proporcionar a mesma disparidade de valor observado neste estudo de caso para quaisquer empresas avaliadas no setor.

Supondo que o método de CORNELL com a suposição de que a estrutura da dívida possa permanecer a mesma independentemente do detentor de ações ordinárias, pode-se desenvolver uma nova estimativa para o valor contábil da empresa, considerando apenas o valor contábil de seu Patrimônio Líquido apresentam valores não confiáveis.

Há de se destacar algumas limitações do método do valor contábil, dentre elas: a não observância do custo de oportunidade do capital investido; a valoração baseada no princípio do custo histórico, que supõe a invariabilidade no tempo dos valores investidos; a inobservância do horizonte de resultados previstos posteriormente à data de avaliação. 


\section{CONCLUSÕES FINAIS}

\subsection{Conclusões obtidas}

A revisão bibliográfica realizada através deste estudo identificou diversas interpretações para as técnicas de avaliação econômico-financeira de uma empresa e para suas respectivas ferramentas. Já discutidos em outros trabalhos acadêmicos, nem todos os autores se dedicam a assumir unanimidade em definir um modelo de avaliação de empresa justo para o cálculo da empresa.

A revisão bibliográfica realizada através deste trabalho apresentou os principais conceitos de valor, os direcionadores de valor das empresas e as principais metodologias de avaliação, com destaque para a avaliação pelo desconto do fluxo de caixa, finalizando com a aplicação de múltiplos setoriais para cada segmento: etanol e biodiesel; suas vantagens e desvantagens.

Dos modelos apresentados, o intuito é discutir as dificuldades e parâmetros adotados para um setor ainda em fase de crescimento no Brasil e no mundo. Diferente de outros setores em que é possível encontrar um histórico de desenvolvimento como é o caso do setor de aço, petróleo, empresas .com, papel e celulose entre outros.

A avaliação por múltiplos demanda a existência de empresas comparáveis à empresa avaliada, a obtenção de seus múltiplos e a definição de qual será utilizado. A seleção de empresas comparáveis pode ser feita com base nas empresas da mesma região e capacidade de produção ou com base nas empresas de características e fundamentos semelhantes ao da empresa objeto de avaliação. Entretanto, existem poucas pesquisas indicando qual a melhor forma de se selecionar empresas comparáveis, nem qual o melhor múltiplo a ser utilizado.

Neste aspecto já tão discutido, abre se mão do uso de outras ferramentas de avaliação por não enquadrarem no estudo do setor, além disso, o método de desconto do fluxo de caixa reflete com maior segurança o horizonte, bem como maior precisão na avaliação, uma vez que para se chegar a um número é necessário conhecer todas as características do setor e empresa.

Neste aspecto o estudo apresentou algumas situações em que baseado na proporção do empreendimento, nível de produção torna-se um ferramental importante para entender diversos aspectos do setor que pode ajudar numa política industrial e a forma de levantar e criar valor para investidores que tenham interesse em se instalar em áreas não atrativas. 
Um exemplo deste é o caso do uso da mamona na produção do biodiesel no Nordeste, que comparados a outros insumos e regiões não é tão atrativo, desta forma contraria uma das políticas governamentais sociais que é a inclusão dos pequenos e médios agricultores do Nordeste brasileiro. Foi possível identificar que a forma introdutória do biodiesel prevalece a construção de grandes usinas baseadas em grandes latifúndios, similar a produção de álcool.

Cabe aqui neste trabalho não levantar questões de cunho político, apenas apresentar numa visão de mercado o comportamento que terá o setor e que na opinião de muitos pesquisadores trarão vantagens significativas para todas as esferas da economia, ou seja, geração de empregos, divisas, aprimoramento de tecnologia e ampliação do capital.

A utilização dos múltiplos mostrou-se importante ferramental, apesar de não ter sido testado para outras empresas. Serve de forte indicador de avaliação de empresas, uma vez que o setor é baseado em commodities, sem diferenças tecnológicas significativas e know-how técnico.

\section{$\underline{\text { Biodiesel }}$}

Dos principais direcionadores para o cálculo do valor da empresa estão os preços dos insumos (girassol, soja, mamona, dendê), preços praticados na venda do biodiesel, estrutura de capital, capacidade de produção.

\section{$\underline{\text { álcool }}$}

Os principais drivers para o cálculo do valor da empresas são: região de atuação, custo de produção e/ou compra da cana, capacidade de moagem, mix álcool/açúcar e estrutura de capital.

\subsection{Sugestões para trabalhos futuros}

Para uma maior avaliação do risco do acionista, um importante estudo seria melhorar a avaliação do beta do beta para cada segmento do setor, uma vez que foram utilizadas empresas de capital aberto em outros países que diferem do momento em que o setor no Brasil vem passando. Estas empresas, não espelham a realidade brasileira, já que este setor não tem importância nestes países como no caso brasileiro. 
Outro estudo importante é levantar os dados do setor de carvão e propor um modelo teórico, o tipo de empresa atual a que se refere este setor, não espelha a sua real importância. Novas tecnologias estão sendo apresentadas para profissionalização deste setor e que vai demandar um estudo para calcular o valor destas companhias, que utilizam esta nova tecnologia na fabricação de carvão e de outros produtos originários da lenha.

Apesar de ainda existir poucas empresas de capital aberto no Brasil e recém integrantes da bolsa, o nível de liquides e a atenção que o mercado tem dado permitem aplicar o modelo nesta empresa e testar a sua validade frente a outras condições de mercado. Isto irá gerar mais dados computados para uma melhor avaliação.

A definição de qual tipo de múltiplo utilizar para cada setor ou país é outra questão que pouco foi debatida pela comunidade acadêmica. Este poderia ser um trabalho ampliado para criar modelos de empresas e aplicá-los para a avaliação de outras empresas do mesmo setor.

\subsection{Limitações do Estudo}

O trabalho foi desenvolvido com apenas uma empresa de cada segmento do setor de biocombustível, desta forma o mesmo poderia ter sido testado em outras empresas para obter uma amostra mais significativa e ajustas as premissas para uma melhor avaliação. 


\section{REFERÊNCIAS BIBLIOGRÁFICAS}

AMARAL, SERGIO, Uma política externa para o século XXI. Revista Política Externa, vol 15 no. 2 , set/out/nov 2006. p. 7.

AMRAM, M., KLATILAKA, N., Real Options: Mamaging Strategic Investment in a Uncertain World. Boston; Harvard Business School Press, 1999. p.6.

AMRAM, M., KLATILAKA, N.. Real Options: Managing Strategic Investment in a Uncertain World. Boston. Harvard Business School Press, 1999.

ASWATH, Damodaran. Avaliação de Investimentos. Rio de Janeiro, Qualitymark, 1997.

BASTOS, L.; PAIXÃO, L.; FERNANDES, L.. Manual para a elaboração de projetos e relatórios de pesquisa, teses e dissertação. $3^{\text {a }}$ edição. Rio de Janeiro: Zahar, 1982.

CASTRO, A. L.; TEIXEIRA, J. L.; MELO, A. C. G. Avaliação de ativos de geração termelétrica e o mercado competitivo de eletricidade no Brasil. In: XXXI SIMPÓSIO BRASILEIRO DE PESQUISA OPERACIONAL, Juiz de Fora, 1999.

COELHO S. T. Mecanismos para Implementação da Cogeração de Eletricidade a partir de Biomassa. Um Modelo para o Estado de São Paulo. (Tese de Doutorado) PIPGE/USP- Programa Interunidades de PósGraduação em Energia, Universidade de São Paulo. São Paulo, 1999.

COPELAND, T. E.; ANTIKAROV, V. Opções reais: um novo paradigma para reinventar a avaliação de invstimentos. Rio de Janeiro: Campus, 2001

COPELAND, T.; KOLleR, T.; MURRIN, J. Avaliação de Empresas - "Valuation" - Calculando e gerenciando o valor das empresas - $3^{\mathrm{a}}$ ed., São Paulo, Makron Books, 2002.

CORNELL, B.. Corporate Valuate Tools for Effective Appraisal and Decision Making. New York: Mc Graw Hill Co..1994.

DAMODARAN, A.. Avaliação de Investimentos: Ferramentas e Técnicas para a Determinação do Valor de Qualquer Ativo. Rio de Janeiro: Qualitymark, 1999.

DUNCAN, R.C.; YOUTHGQUIST, W. The world petroleum life-cycle. Los Angeles: University of Southern California, 22 Oct. 1998. Dispositivo em: http://www.dieoff.com/page133.pdf

GOLD, Steven System-dynamics-based modeling of business simulation algorithms. Simulation \& Gaming Thousand Oaks:Jun 2005. Vol. 36, Iss. 2, p. 203-218. 
GOLDEMBERG, J. Energia , Meio Ambiente e Desenvolvimento. EDUSP. 1996.

GOLDEMBERG, J., Ethanol Learning Curve: the brazilian experience. Biomass and Bioenergy, no 26, p. $301-304,2003$.

Goldemberg, J.; COElho, S.T.; LuCON, O. How Adequate Policies can Push Renewables. Energy Policy, no 32, p. $1141-1146,2004$.

GOLDEMBERG, J.; COELHO, S.T.; LUCON, O.; GUARBADASSI, P. Brazilian Sugarcane Ethanol: Lessons Learned. Paper prepared for STAP workshop on Liquid Biofuels, Delhi, September, 2005.

GRIMONI, J. AQUILES; GALVÃO, L. CLAUDIO; UDAETA, M. EDGARD. Iniciação a Conceitos de Sistema Energéticos para o Desenvolvimento Limpo. EDUSP. 2004

GRINOLD, Richard; KAHN, Ronald N. Active Portfolio Management, Quantitative theory and Applications, McGraw-Hill, 1995.

HELFERT, E.A.. Técnicas de Análise Financeira - um guia prático para medir o desempenho dos negócios. $9^{\text {a }}$. Edição. Porto Alegre: Bookman, 2000.

IEA (International Energy Agency). Key World Energy Statistics. Paris. www.iea.org. 2006

KAPLAN, S. Energy Economics. McGraw Hill. 1983.

MARKONI, M. A.; LAKATOS, E. M. Metodologia Cientifica. $3^{\text {a }}$ edição. São Paulo: Atlas, 2000.

MARTINS, G. A. Manual para elaboração de monografias e dissertações. $3^{\text {a }}$ edição. São Paulo: Atlas, 2002.

MODiGLiAni, F., MILLER, M.H. The cost of capital, Corporation Finance and the Theory of Investment. American Economics Review, XLVII (junho de 1958), p. 655-6.

MODIGLIANI, F., MILLER, M.H.. "The cost of capital, Corporation Finance and the Theory of Investment". American Economics Review, XLVII (junho de 1958).

MYERS, S. C. Determinants of corporate borrowing. Journal of financial ecnonomics. n.5. p. 147-1475. Nov. 1977.

NASTARI, P. M.. Os atuais mercados consumidores e os mercados potenciais - parceria e estratégia de negócios e a garantia de ofertas. In: SEMINÁRIO O BRASIL E A ENERGIA DO SÉCULO 21: AÇUCAR E ETANOL. Brasília, 2004.

NOGUEIRA, A. A.. Metodologia para determinação do valor das empresas: uma aplicação no setor têxtil. 1999. Dissertação (Mestrado em Administração) - Faculdade de Economia. Administração e Contabilidade de São Paulo, São Paulo. 
PARK, C.; SHARPE-BETTE, G.. Advanced engineering ecnomics. New York: John Wiley \& Sons, 1990.

RAPPAPORT, A., Creating Shareholder Value: The New Standard for Business Performance. New York: The Free Press, 1996. p.14.

ROSS, S.A., WESTERFIELD, R.W., JORDAN, B.D., Princípios de Administração Financeira.

SAUAIA, Antonio Carlos Aidar Evaluation of performance in business games: financial and non financial approaches. Developments in Business Simulation and Experiential Learning, Volume 28, 2001.

SAVOIA, JOSE ROBERTO FERREIRA - Organizador. A inserção do Brasil na Comunidade Internacional: Desafios e Oportunidades. Center for Brazilian Studies - Columbia University. 2005.

SECURATO, J. R.. Decisões financeiras em condições de risco. São Paulo: Atlas, 1996.

SHARPE, W.. Portfolio Theory and Capital Markets. New York: MacGraw-Hill, 1970.

STERN, NICHOLAS. Review on the economics of climate changed. London, UK. Dispositivo em: http://www.hm treasury.gov.uk/independent reviews/stern review economics cimate changed.htm

VERGARA, Sylvia C. Projetos e relatórios de pesquisa em administração. 2. ed. São Paulo: Atlas, 1998. 90p.

WALKER, IGNACIO. Qual o caminho da globalização, da democracia e da esquerda na América Latina? Revista Política Externa, vol 15 no. 2, set/out/nov 2006. p. 21.

YIN, R. K. Case Study Research - Design and methods. 2a ed. Thousand Oaks: Sage Publications, 1994. 
ANEXO 1

\section{BIODIESEL}


ANEXO 2

ÁLCOOL 